\title{
Beyond the struggles
}

Citation for published version (APA):

Atherley, A. E. N. (2021). Beyond the struggles: Using social-developmental lenses on the transition to clinical training. [Doctoral Thesis, Maastricht University, Western Sydney University]. Maastricht University. https://doi.org/10.26481/dis.20210927aa

Document status and date:

Published: 01/01/2021

DOI:

10.26481/dis.20210927aa

Document Version:

Publisher's PDF, also known as Version of record

\section{Please check the document version of this publication:}

- A submitted manuscript is the version of the article upon submission and before peer-review. There can be important differences between the submitted version and the official published version of record.

People interested in the research are advised to contact the author for the final version of the publication, or visit the DOI to the publisher's website.

- The final author version and the galley proof are versions of the publication after peer review.

- The final published version features the final layout of the paper including the volume, issue and page numbers.

Link to publication

\footnotetext{
General rights rights.

- You may freely distribute the URL identifying the publication in the public portal. please follow below link for the End User Agreement:

www.umlib.nl/taverne-license

Take down policy

If you believe that this document breaches copyright please contact us at:

repository@maastrichtuniversity.nl

providing details and we will investigate your claim.
}

Copyright and moral rights for the publications made accessible in the public portal are retained by the authors and/or other copyright owners and it is a condition of accessing publications that users recognise and abide by the legal requirements associated with these

- Users may download and print one copy of any publication from the public portal for the purpose of private study or research.

- You may not further distribute the material or use it for any profit-making activity or commercial gain

If the publication is distributed under the terms of Article $25 \mathrm{fa}$ of the Dutch Copyright Act, indicated by the "Taverne" license above, 


\section{Beyond The Struggles:}

Using social-developmental lenses on the transition to clinical training

By:

Anique Elizabeth Nathania Atherley 
The research reported here was carried out at

\section{WESTERN SYDNEY} UNIVERSITY

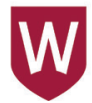

and

\section{Maastricht University}

in the School of Health Professions Education
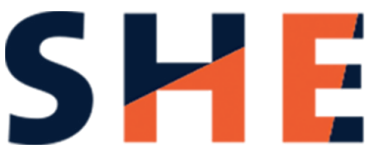

School of

Health Professions

Education

in the context of the research school

(Interuniversity Center for Educational Research)

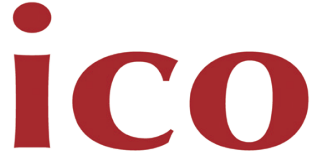

and was funded by

Western Sydney University

(c) Anique Elizabeth Nathania Atherley, 2021

Cover graphic design by Anique Atherley

Printing: Ipskamp

ISBN: 978-94-6423-166-3 


\title{
Beyond The Struggles: \\ Using social-developmental lenses \\ on the transition to clinical training
}

\author{
Dissertation
}

to obtain a double doctoral degree of

Doctor at Maastricht University,

on the authority of the Rector Magnificus, Prof. dr. Rianne M. Letschert, in accordance with the decision of the Board of Deans, and

Doctorate of Philosophy at Western Sydney University to be defended in public on Monday 27 September 2021, at 10:00 hours

by 


\section{Supervisors:}

Prof. dr. D.H.J.M. Dolmans

Prof. dr. W.C. Hu, Western Sydney University, Australia Prof. dr. P.W. Teunissen

\section{Co-supervisor:}

Dr. I. Hegazi, Western Sydney University, Australia

\section{Assessment committee:}

Prof. dr. C.P.M. van der Vleuten (Chair)

Prof. dr. J. Cleland, Nanyang Technological University, Singapore

Prof. dr. F. Scheele, Amsterdam UMC, the Netherlands

Dr. P. Abbott, Western Sydney University, Australia 
Year of submission

2021 



\section{Statement of Authentication}

The work presented in this thesis is, to the best of my knowledge and belief, original except as acknowledged in the text. I hereby declare that I have only submitted this material, either in full or in part, to any other institution apart from Maastricht University and Western Sydney University. This thesis is the product of a dual award (double degree) at these institutions.

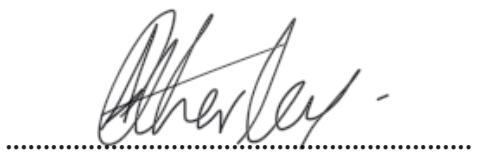

(Signature) 


\section{Declarations}

\section{Funding:}

This thesis is the result of a Dual PhD Programme between Western Sydney University and Maastricht University. Anique Atherley was a recipient of the PhD Scholarship that provided a stipend that made the research in this thesis possible.

Anique Atherley received the Medical Education Travelling Fellowship Grant in 2019

\section{Conflicts of Interest:}

NONE 


\section{TABLE OF CONTENTS}

$\begin{array}{ll}\text { List of Tables } & 10\end{array}$

$\begin{array}{ll}\text { List of Boxes } & 11\end{array}$

$\begin{array}{ll}\text { List of Figures } & 12\end{array}$

$\begin{array}{ll}\text { Abstract } & 14\end{array}$

$\begin{array}{ll}\text { Chapter One } & 17\end{array}$

General Introduction

Chapter Two 31

Beyond the struggles: a scoping review on the transition to undergraduate clinical training Published as Atherley, A. et al. Medical Education, 2018

Chapter Three

Journey to becoming: Exploring students' lived reality and identity formation across the transition to clinical training

Under Review

Chapter Four

Students' social networks are diverse, dynamic and deliberate when transitioning to clinical training

Published as Atherley, A. et al. Medical Education, 2020

Chapter Five

Socialisation tactics when entering a new clinical clerkship: a mixed methods study of proactivity

Under Review

Chapter Six

Appraising the use of smartphones and apps when conducting qualitative medical education research: AMEE Guide No. 130

Published as Atherley, A. et al. Medical Teacher, 2021

Chapter Seven

General Discussion

Summary

Samenvatting

Impact Paragraph

Appendices

About Anique

List of Publications

Acknowledgements

SHE Dissertation series

ICO Dissertation series

Beyond the struggles: a research poem 


\section{LIST OF TABLES}

\section{Chapter One}

Table 1: PhD Thesis Overview for all empirical chapters

\section{Chapter Two}

Table 1: Perspectives taken on the transition from pre-clinical to

clinical training in the literature

Appendix S1: Data charting form

\section{Chapter Three}

Table 1: Participants' descriptions

Table 2: Sample prompts, sample questions from interview guides

and timing within the study period

Appendix | Table 1: Audio-diary prompts

Appendix | Box 1: Interview schedule

\section{Chapter Four}

Table 1: Proportion of alters in each of 8 roles at T0 and T1 showing

increased doctor and peer ties and decreased near-peer and nursing ties

\section{Chapter Five}

Table 1: Average scores for each individual survey item in a sample

clinical student population in Australia, 2020

Table 2: Average scores regarding proactive behaviors and

social integration showing differences between academic year groups

in a sample clinical student population in Australia, 2020

Table 3: Overview of six themes describing factors that influenced

medical students' proactive behavior when entering a new clerkship

\section{Chapter Six}

Table 1: Sample data management plan summary 


\section{LIST OF BOXES}

Chapter Two

Box 1: Search strategy for PubMed 35

Box 2: Inclusion and exclusion criteria for this scoping review 36

Box 3: Three conceptual perspectives used to approach the transition 38

from pre-clinical to clinical training

Chapter Four

Box 1: Semi-structured interview guide: sample questions

\section{Chapter Six}

Box 1: Sample data management data flow system

Box 2: Ten lessons for using smartphones in

qualitative medical education research 


\section{LIST OF FIGURES}

Chapter Two

Figure 1: Flowchart of the search process and results for this scoping review

\section{Chapter Three}

Figure 1: Data collection procedures for this paper

Figure 2: Annotated research poem of data entitled 'becoming'

\section{Chapter Four}

Figure 1: Data collection procedures for two related by distinct studies.

Bold and underlined text indicate the data collected for the current study

Figure 2: These images show the procedures used in this study to create target

sociograms which represented the support networks of our participants

Figure 3: David's network at T0 had 15 alters from 6 role groups

Figure 4: Nicole's network at T0 $(n=19))$ and T1 $(n=20)$

\section{Chapter Five}

Figure 1: Process of integrated mixed methods analysis for this study

Figure 2: Integrated themes generated from mixed methods study conducted in Australia in 2020 indicating three antecedents for proactive behaviour 
"Change.

we don't like it,

we fear it,

but we can't stop it from coming.

We either adapt to change

or we get left behind.

And it hurts to grow,

anybody who tells you it doesn't is lying."

Dr. Meredith Grey,

General Surgery Attending

Grey's Anatomy Season 4 


\begin{abstract}
Transitions are inevitable. Transition discourse often focuses on the stress associated with entering a new phase of training. Medical educators and researchers have sought to eliminate transition stress with limited success. Recent transition literature has called for new perspectives on the transition 'problem' to optimise students' adaptation to change. This thesis aimed to enhance our understanding of how undergraduate medical students navigate the transition from pre-clinical to clinical training using sociocultural lenses. We first conducted a scoping review (Chapter Two) exploring how researchers have approached the transition from pre-clinical to clinical training and identified the gaps in these approaches. Following the scoping review, we created two overarching questions that address to our research agenda. 1) In what ways does the transition from pre-clinical to clinical training contribute to medical students' professional and personal identity development? 2) What role do social relationships play in students' transition from pre-clinical to clinical training?
\end{abstract}

Chapters Three through Five represent individual empirical studies and publications each conducted within the five-year Bachelor of Medicine, Bachelor of Surgery (MBBS) undergraduate medical programme at Western Sydney University in Australia between 2018 and 2020. Chapter Three is a qualitative longitudinal study in which nine pre-clinical students submitted regular audio diary entries and participated in two interviews as they transitioned to clinical training. Eight of these students also participated in qualitative social network research in Chapter Four. For this study, students mapped their social support networks in the first and fifth months of clinical training. Chapter Five is a mixed-methods study using surveys ( $n=200)$ and interviews $(n=18)$ to explore proactive behaviour and its relationship to students' sense of social integration as they enter a new clerkship. For each study, we used sensitising concepts from different sociocultural lenses - landscapes of practice, social network theory and organisational socialisation.

Chapter Two, the scoping review, discovered that researchers view the transition to clinical training from an educational perspective, and mainly focussed on the gap in knowledge and skills needed for the next phase. Chapter Three showcases that students undergo identity development as they transition by taking charge of learning opportunities. They shape their self-image through becoming more engaged, identify role models and flexibly adapt to new clerkship norms by managing expectations and adopting a journey mindset. Next, Chapter Four found that students' social networks were diverse and dynamic; students deliberately finetune their social networks as they identify relationships that serve their development through emotional and instrumental functions. Chapter Five adds that negotiating tasks was a challenging proactive behaviour (PB) for clinical students entering a new clerkship. Individual factors like 
personal interest and mental energy impacted whether students intended to be or felt like they were capable of PB. Students' networks also created a safe space where they felt motivated to be vulnerable as they practised lifelong skills (e.g., being proactive). Smartphones were a critical research tool to carry out our research in Chapter Three; hence, we critically appraised using smartphones for qualitative data collection in Chapter Six, a guide for researchers.

We conclude that the transition to clinical training is an opportunity for student identity and lifelong skill development (e.g. proactive behaviour); our explicit consideration of identity formation shows this. It occurs when students went from being pre-clinical students to becoming clinical students working and learning around patients. We also conclude that the transition to clinical training is an opportunity for students' social network development and utilisation. We found that students' networks are diverseincluding family, peers, near-peers, doctors, academic staff, nurses; dynamic-they change significantly over time; and deliberate-students made choices about who was in their social support networks. We lastly conclude that the transition to clinical training is both a threat and an opportunity for learning and development; a developmental networking asset. Students' lived reality of this tension between opportunity and threat will depend on educators shifting their transition-related perspectives, and creating supportive environments for the transitioning student.

\section{Keywords:}

transition; clinical training; social networks; identity development; proactive behaviour; smartphones 


$$
1
$$




\section{General Introduction}


Do you remember the first time you entered university? When you started your first job after university? The first time you started postgraduate training? Do you remember the emotions you felt, the challenges you had, and the knowledge and skills you learned?

In medicine, medical students and doctors experience numerous transitions during training, bringing changes in context, relationships and responsibility. A transition is a not a moment, but 'a dynamic process in which the individual moves from one set of circumstances to another ${ }^{11}$; Kilminster aptly described transitions as critically intensive learning periods (CILPs) ${ }^{2}$. One crucial transition in a medical trainee's life occurs during undergraduate training when a medical student moves from pre-clinical, classroombased, to clinical training based around patient care. While initial transition literature focused on the negative associations with stress and anxiety ${ }^{3-5}$, researchers increasingly highlight the opportunities inherent in transition periods during medical training ${ }^{1,6,7}$. So, are transitions an opportunity for, or a threat to, learning and development of medical trainees? Regardless, transitions during the medical continuum are inevitable and occur due to both healthcare systems and the educational continuum. This thesis aims to expand our understanding of how undergraduate medical students navigate the transition from pre-clinical to clinical training.

\section{Why are there transitions during medical training?}

Transitions are everywhere - in professional and everyday life; in nature and humankind. In medicine, following Abraham Flexner's landmark report in the United States and Canada, medical schools restructured medical education ${ }^{8}$. This restructuring meant that students first spend time learning in the classroom before learning through patient care $^{8}$. Flexner propositioned that during medical school, the medical student must first develop analytical skills in basic sciences (e.g. histology and pharmacology) followed by clinical exposure in hospitals (e.g. surgery and paediatrics) ${ }^{8}$. Since Flexner's report, many medical schools started structuring training into pre-clinical training (mainly in the classroom) studying basic medical sciences and clinical training (mostly around patients) applying basic sciences to patient care. This model is still dominant today. Therefore, medical students experience a transition when they leave basic science training and enter clinical training.

Further, given the explosion of medical specialities over the past 100 years, medical schools seek to dip students in and out of as many speciality areas as is possiblerotation-based clinical training. Together, this creates the 'Flexnerian curriculum' of medical training with many transitions ${ }^{9}$. Recently, some medical schools are adjusting this traditional structure in two ways. First, some medical schools provide early clinical experiences and bring patients to the classroom while also taking basic sciences to clinical training ${ }^{5,10,11}$. Next, some medical schools have abandoned rotation-based 
clerkships favouring longitudinal clerkships where students experience one clinical environment for a prolonged period ${ }^{12}$. These innovations resulted from evidence highlighting the threats to learning and development posed by the transition to clinical training ${ }^{3-5}$, and further so with frequent changes between clerkships ${ }^{13}$. This thesis specifically focuses on this transition from pre-clinical to clinical training, as this is the first transition within the medical education continuum. Further, authors suggest that transition skills - behaviours that allow an individual to navigate complex situational changes, including in higher education-can be learned ${ }^{14}$.

\section{Transition to clinical training: a threat to- or an opportunity for learning and development?}

Many medical educators and researchers frame the transition to clinical training as a problem to be eliminated. Research, primarily cross-sectional in origin, shows that many medical students struggle with fitting into the clinical environment once they enter

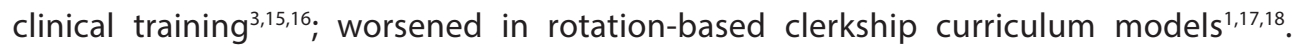
Additionally, research suggests that this transition results in significant anxiety, and some students struggle to find their role and develop an identity that aligns well with role expectations in their new clinical environment ${ }^{19-21}$. With each new clerkship, students encounter a unique community of doctors, nurses and patients. Students learn clerkship norms from this community as they build relationships. Relationships between students and others in the clerkship community can influence how they adapt to a new environment ${ }^{22}$. These struggles are important to consider because some research suggests the associated emotional stress could negatively impact learning ${ }^{23,24}$. Further, these threats prompted educators and researchers to see transitions as a struggle ${ }^{13,25-27}$ - transition as problematic perspective - and to find ways to deal with this problem and 'smoothen' transitions in training ${ }^{28}$.

Researchers and educators in medicine have designed numerous curriculum innovations to optimise the transition to clinical training and minimise the threats this transition poses. These innovations are often didactic transition courses ${ }^{29}$, lasting up to a few days, preparing students with the knowledge and skills for their new context and workplace norms(4). These transition courses have, reduced anxiety ${ }^{4}$, improved confidence ${ }^{30,31}$ and learning 4,32,33 but research still reports that students feel stressed and anxious about the transition ${ }^{4,20,29}$. Transition courses are often at a group-level and classroom-based even though the clinical environment is social, dynamic and complex ${ }^{4,17,29}$. Further, efforts to eliminate transitions indicate this will never be possible; transitions remain inevitable. This recently prompted a few researchers and educators in medicine consider the opportunities that the transition to clinical training brings $\mathrm{s}^{1,34}$. 
A few authors highlight the benefits of empowering students through challenging transition periods $22,26,35,36$ or highlight the potential for stressful experiences to trigger personal and professional development ${ }^{37}$. Guided, written narratives completed at the end of pre-clinical training allowed students to recognise aspects from pre-clinical training that helped their anxiety for the future clinical environment and allowed them to reflect on the type of doctor they wanted to $b^{35}$. Reflective interviews helped students assess their progress and critically evaluate how current experiences were essential to optimise work-based learning ${ }^{33}$. Reflection using audio diaries were used longitudinally over nine months among postgraduate trainees as they became trained specialists and showed that formal and informal relationships are critical to helping trainees to transition ${ }^{6}$. Reflection is an area that has been minimally studied for its impact on the transition to clinical training but could be essential to help students recognise vital experiences $^{38}$ as they develop.

The lack of literature highlighting the opportunities inherent in transition periods is unfortunate as experiences, critical reflection and dialogue with others regarding stressful experiences can transform one's existing perspective of self, beliefs, and behaviours ${ }^{37}$. Moreover, Wenger suggests that transitions bring new experiences and relationships and represent a critical point in identity formation ${ }^{39}$.

\section{What is missing?}

Researchers recently recognise that there is a missing piece of the puzzle in how medical education transitions are framed ${ }^{7}$. Research in medical education infrequently explores identity formation during critical transition periods. Further, although transitions are dynamic with the potential to contribute to a medical students' development and growth, there have been few longitudinal approaches across any transition during the medical trajectory ${ }^{6}$, including the transition from pre-clinical to clinical training. There are increasing calls to advance educators' and researchers' approaches to transitions in general. Yardley and colleagues suggest that new outcomes beyond students' perceptions of confidence and anxiety are necessary to move transition research forward. As Yardley et al. remind $\mathrm{us}^{38}$, our current views about transitions likely influence how we approach these critically intensive learning periods (CILPS) ${ }^{2}$. Similarly, O'Brien suggests framing the transition to residency as a transformative process, an opportunity for development, rather than a problem to be solved ${ }^{7}$.

\section{Framing this work}

The limited literature acknowledging the contextual aspects of the transition to clinical training and other shifts in the medical continuum led us to situate this thesis in theoretical concepts from sociocultural lenses - the landscapes of practice model, social network theory and organisational socialisation theory. Wenger developed the 
concept of landscapes of practice ${ }^{39}$ by revisiting his earlier work on communities of practice (CoP) $)^{39}$. Wenger and colleagues note that people build complex relations across a dynamic landscape when learning in a profession and slowly become knowledgeable and competent in the profession over time. Thus, Wenger suggests that both knowledgeability and competence are social, and not individual, constructs ${ }^{39}$. When individuals join and leave a community of practice, Wenger describes a significant boundary that is crossed ${ }^{40}$, this correlates to what we have been discussing as a transition. When traversing a professional landscape, learning is not just acquiring knowledge but also about the becoming of the person entering and functioning in a new landscape ${ }^{39}$. Boundary crossing and navigating multiple CoPs over time influences identity development ${ }^{40}$. This thesis used sensitising concepts from landscapes of practice to explore undergraduate medical students' identity development transitioning to the clinical environment.

The influence of others on newcomers' development, especially during transition periods is underexplored in medical education research. Social network theory offers us concepts and a methodology to explore this social influence and unpack the structure and function of social relationships relevant to a transition period. We used sensitising concepts, and an approach grounded in social network theory to explore the 'others' that influence students transitioning to the clinical environment.

Lastly, organisational socialisation theory considers the role of the organisation in influencing socialisation of newcomers to the workplace ${ }^{17,41}$ and the antecedents for true integration when entering a new work environment. For example, newcomers who are proactive and organisations that use intentional tactics to promote socialisation result in newcomers becoming a functioning member of the workplace while developing mastery of work tasks ${ }^{42}$. In medicine, medical students enter a new workplace when they begin learning from patients to develop clinical skills; thus, notions from organisational socialisation become relevant. Faculty in medical education often desire proactive students and proactive behaviour is an individual tactic that can help students develop a sense of social integration into the clinical environment. Therefore, we used sensitising concepts from organisational socialisation to explore proactivity in a medical education context.

\section{Toward a research agenda and specific research questions}

Much research in HPE related to transitions, including that from pre-clinical to clinical training, uses narrow conceptualisations of the term transition ${ }^{7}$. We have argued above that transitions during medical training are both a threat and an opportunity for medical students and doctors' learning and identity development. However, it is also clear that new perspectives and approaches to the transition to clinical training 
are necessary to inform new strategies to help medical students and trainees adapt to change. New perspectives can be stimulated by looking to new theoretical frames. New perspectives can also be encouraged by considering how we approach transition research both practically and methodologically. Thus, we set out to address a research agenda that sought to highlight new perspectives to the transition from pre-clinical to clinical training in medical education and provides suggestions to move this field forward in a meaningful way.

Therefore, this $\mathrm{PhD}$ thesis has one overarching aim: to enhance our understanding of how undergraduate medical students navigate the transition from pre-clinical to clinical training using sociocultural lenses. To meet this aim, we first conducted a scoping review exploring how researchers have approached the transition from pre-clinical to clinical training and identified the gaps in these approaches. From this review, we determined what empirical studies were necessary and created a research agenda to advance evidence and contribute meaningful strategies to help students navigate change. This first step was essential before building on existing literature as it was not yet clear, what gaps exist in the field's approaches to transitions. This scoping review (Chapter Two) revealed that medical education researchers mainly approach the transition to clinical training from an educational perspective of what knowledge and skills the medical students bring to the clinical environment and what they lack. As all other chapters build on information in both this current chapter and Chapter Two, we created two overarching questions for the other empirical chapters in this thesis that address our research agenda.

\section{1) In what ways does the transition from pre-clinical to clinical training contribute to} medical students' professional and personal identity development? Chapters Three and Five contributed to this first question. The scoping review highlighted that research from a developmental perspective was limited. These authors focused on empowering students with lifelong learning skills-adaptation and being self-directed. Students completed audio-diary recordings during the research in Chapter Three as they transitioned from pre-clinical to clinical training, allowing us to explore their lived reality and identity formation. Further, in Chapter Five, we explored a specific developmental behaviour - individual students' proactive behaviours - and the extent to which proactivity influenced their transition experiences and sense of social integration in a clerkship. 2) What role do social relationships play in students' transition from preclinical to clinical training? Chapters Four and Five contributed to this question. The scoping review highlighted that social perspectives to the transition to clinical training were limited and that social relationships could influence newcomer experiences and development. In Chapter Four, we explored a transition from a social perspective by unpacking students' social support networks as they transitioned from pre-clinical to 
clinical training. Further, in Chapter Five, we describe findings that social context affects students' ability to exhibit proactive behaviour.

In our background reading, research team conversations and the scoping review, we recognised that most transition literature used similar research approaches, often cross-sectional- surveys, interviews and focus groups. Researchers admitted the limitations and potential for recall bias given that they collected data before or after students had 'transitioned' to a new environment. Therefore, we added to our research agenda, the need to contribute a longitudinal exploration of the transition from preclinical to clinical training. We deemed it essential to use data collection methods that aligned with a need to collect students' experience and perspectives while transitioning. Collecting data during students' transition experiences was fruitful by minimising recall bias as previously described; students could provide insights as their experiences were occurring. As we fine-tuned our research protocols, we made evidenced-based decisions on the opportunities and drawbacks of using smartphones to collect data. Chapter Six is an appraisal of using technology - smartphones - to collect data given that other fields found this had the potential to provide 'just-in-time' information to researchers studying specific processes.

\section{Context}

We conducted all studies in this dissertation within the five-year Bachelor in medicine; Bachelor in Surgery (MBBS) undergraduate medical programme at Western Sydney University in Australia with cohorts of up to 130 medical students between 2018 and 2020. These cohorts comprise mostly school-leavers, and cohorts are often diverse, with $30 \%$ international students. In this programme, undergraduate students spend two years in pre-clinical training with a problem-based learning component. Students experience a transition day during their second year, shadowing a third-year student on the wards. Students then enter clinical training in their third year where they rotate through clerkships, in groups of approximately 20, at sites across New South Wales. Three times per year, each year group attends a week of on-campus large-group teaching sessions, where all students in the cohort receive didactic lectures and tutorials on clinical skills and specific knowledge to aid their transition to clinical environments.

\section{Thesis Overview}

This thesis presents four empirical studies that contribute to our understanding of the transition's social and developmental aspects of clinical training. Table one summarises the titles, research questions, study design theoretical framework and data sources for each chapter that follows. In Chapter Six, we offer an appraisal of using smartphones to collect qualitative data. In Chapter Seven, we synthesise findings to answer our overarching research questions, and discuss the implications of our findings and 


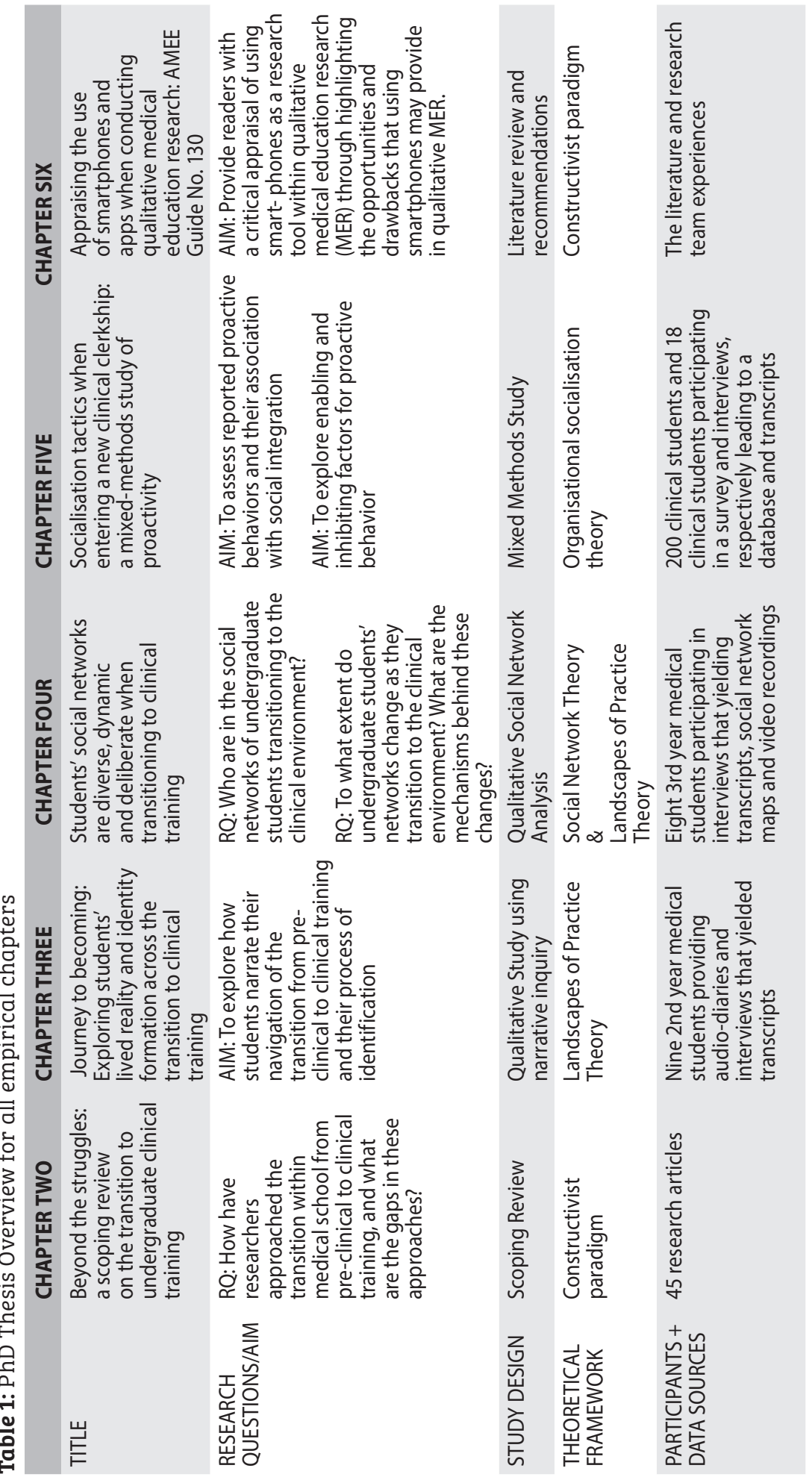


acknowledge both the strengths and weaknesses in our procedures. Lastly, an impact paragraph describes the scientific and societal impact these findings can and have had on real-life issues. Since this thesis constitutes published journal articles, some repetition is unavoidable. Additionally, each journal dictated its English type (e.g. British or American English) and citation style (e.g.Vancouver); we maintained journals' formats in each published chapter, so some inconsistencies in these areas are expected.

\section{Reflexivity}

Reflexivity is critical in qualitative inquiry ${ }^{43}$. I used qualitative inquiry throughout this entire thesis. In this section, I hope to bring awareness to myself and my readers regarding my role in the co-construction of the knowledge within this thesis. In this section, I will refer to in the first-person singular given the very personal introspection necessary. All other sections will use first-person plural terms given the collective efforts by myself with my research 'A-team'. This research programme explored the transition that medical students experience as they go from pre-clinical to clinical training. We used multiple data sources and theoretical perspectives but always toward a constructive paradigm. As a researcher situating herself towards the constructive side of research paradigms, I recognise the importance of researcher reflexivity ${ }^{44}$. Therefore, below I briefly describe how my historical, biographical and social perspectives could have shaped my decisions as I conducted, refined and present this research.

I am a Black female from a small island-Barbados. I grew up in a middle-class family with both parents. I entered pre-clinical years of medical school as a layperson in a close-by, but a very different, country - Jamaica. I then returned to Barbados to complete the clinical years of medical school. I exited medical school a health professional. I soon left clinical practice behind in favour of public health and medical education research, ultimately falling in love with education. This PhD trajectory uprooted me once again from Barbados. I temporarily lived in The Netherlands, a country that primarily speaks a language I previously never heard. In Australia, I was over 18,000km away from home, where I experienced a few instances of racial tension. Therefore, l, am the product of multiple life and career transitions and have been trying to fit into numerous communities of practice across the world, in multiple disciplines and in various countries where people that looked like me were in the vast minority. Therefore, my interest in transitions is not surprising, but it does mean I have some preconceived notions about this topic. Through my experiences and prior research, I believed transitions threatened learning and development as many medical trainees experience anxiety and stress when experiencing shifts in physical spaces. By reflecting, discussing findings and the literature with my team and writing an evidence-based scoping review, I became aware of and acknowledged my preconceived notions. I now recognise, appreciate and hope to unpack the opportunities that critical periods of change can provide to individuals once they are in supportive environments. 
I drew on five years of medical education research experience when I started this research programme. I had a choice of my topic of study and my research stance. Even though in biomedical science, objective measures are the gold standard according to many, this was at odds with my inner perspective that subjectivity is beautiful and the only objective truth I believed was that reality is different for everyone. Therefore, I sought methodologies and research approaches aligning with my perspective which led me to participatory data collection methods such as using participants' phones to collect in-the-moment data and actively creating research data with participants. In this way, I affected my study design choices. I will present reflexivity on other aspects in the research process-data analysis, interpretation and presentation - in Chapter Seven toward the end of the discussion. I do this to offer readers a chance to engage in all other chapters before reading my own reflexive choices that resulted in the data presented. 


\section{REFERENCES}

1. Teunissen PW, Westerman M. Opportunity or threat: The ambiguity of the consequences of transitions in medical education. Medical education. 2011;45(1):51-59.

2. Kilminster S, Zukas M, Quinton N, Roberts T. Preparedness is not enough: Understanding transitions as critically intensive learning periods. Medical education. 2011;45(10):1006-1015.

3. Hayes K, Feather A, Hall A, et al. Anxiety in medical students: Is preparation for full-time clinical attachments more dependent upon differences in maturity or on educational programmes for undergraduate and graduate entry students? Medical Education. 2004;38(11):1154-1163.

4. Chittenden EH, Henry D, Saxena V, Loeser H, O'Sullivan PS. Transitional clerkship: An experiential course based on workplace learning theory. Academic Medicine. 2009;84(7):872-876.

5. Wenrich M, Jackson MB, Scherpbier AJ, Wolfhagen IH, Ramsey PG, Goldstein EA. Ready or not? Expectations of faculty and medical students for clinical skills preparation for clerkships. Med Educ Online. 2010;15(1):5295.

6. Gordon L, Jindal-Snape D, Morrison J, et al. Multiple and multidimensional transitions from trainee to trained doctor: A qualitative longitudinal study in the uk. BMJ open. 2017;7(11):e018583.

7. O'Brien $B C$. What to do about the transition to residency? Exploring problems and solutions from three perspectives. Academic Medicine. 2018;93(5):681-684.

8. Flexner A. Medical education in the united states and canada: Arno Press; 1972.

9. Holmboe E, Ginsburg S, Bernabeo E. The rotational approach to medical education: Time to confront our assumptions? Medical education. 2011;45(1):69-80.

10. Dornan T, Bundy C. What can experience add to early medical education? Consensus survey. Bmj. 2004;329(7470):834.

11. Yardley S, Brosnan C, Richardson J. The consequences of authentic early experience for medical students: Creation of mētis. Medical education. 2013;47(1):109-119.

12. Konkin DJ, Suddards C. Students' experiences of role, relationships and learning in two clerkship models. Medical Education. 2017;51(5):490-497.

13. O'Brien B, Cooke M, Irby DM. Perceptions and attributions of third-year student struggles in clerkships: Do students and clerkship directors agree? Academic Medicine. 2007;82(10):970-978.

14. Cheng M, Pringle Barnes G, Edwards C, Valyrakis M, Corduneanu R. Transition skills and strategieskey transition skills at the different transition points: Enhancement Themes; 2015.

15. Knobloch A, Ledford C, Wilkes S, Saperstein A. The impact of near-peer teaching on medical students' transition to clerkships. Family medicine. 2018;50(1):58-62.

16. Balmer DF, Richards BF, Varpio L. 'How students experience and navigate transitions in undergraduate medical education: An application of bourdieu's theoretical model': Erratum. Advances in Health Sciences Education. 2015;20(4):1087-1087.

17. Atherley A, Hambleton IR, Unwin N, George C, Lashley PM, Taylor CG. Exploring the transition of undergraduate medical students into a clinical clerkship using organizational socialization theory. Perspectives on medical education. 2016;5(2):78-87.

18. Bernabeo EC, Holtman MC, Ginsburg S, Rosenbaum JR, Holmboe ES. Lost in transition: The experience and impact of frequent changes in the inpatient learning environment. Academic Medicine. 2011;86(5):591-598.

19. Van Hell EA, Kuks JB, Schönrock-Adema J, Van Lohuizen MT, Cohen-Schotanus J. Transition to clinical training: Influence of pre-clinical knowledge and skills, and consequences for clinical performance. Medical education. 2008;42(8):830-837.

20. SARIKAYA O, CIVANER M, KALACA S. The anxieties of medical students related to clinical training. International Journal of Clinical Practice. 2006;60(11):1414-1418. 
21. Small R, Soriano R, Chietero M, Quintana J, Parkas V, Koestler J. Easing the transition: Medical students' perceptions of critical skills required for the clerkships. Education for Health. 2008;21(3):192-192.

22. McKee A, Markless S. Using action learning sets to support students managing transition into the clinical learning environment in a uk medical school. Action Learn. 2017;14(3):275-285.

23. Prince $\mathrm{KJ}$, Boshuizen HP, van der Vleuten $\mathrm{CP}$, Scherpbier AJ. Students' opinions about their preparation for clinical practice. Med Educ. 2005;39(7):704-712.

24. Moss F, McManus I. The anxieties of new clinical students. Medical education. 1992;26(1):17-20.

25. O'Brien BC, Poncelet AN. Transition to clerkship courses: Preparing students to enter the workplace. Acad. Med. 2010;85(12):1862-1869.

26. Cho KK, Marjadi B, Langendyk V, Hu W. Medical student changes in self-regulated learning during the transition to the clinical environment. BMC Med Educ. 2017;17(1):59.

27. Berkhout JJ, Helmich E, Teunissen PW, van der Vleuten CPM, Jaarsma ADC. How clinical medical students perceive others to influence their self-regulated learning. Medical Education. 2017;51(3):269-279.

28. White CB. Smoothing out transitions: How pedagogy influences medical students' achievement of self-regulated learning goals. Advances in Health Sciences Education. 2007;12(3):279-297.

29. Poncelet A, O'Brien B. Preparing medical students for clerkships: A descriptive analysis of transition courses. Academic Medicine. 2008;83(5):444-451.

30. van Gessel E, Nendaz MR, Vermeulen B, Junod A, Vu NV. Development of clinical reasoning from the basic sciences to the clerkships: A longitudinal assessment of medical students' needs and selfperception after a transitional learning unit. Med Educ. 2003;37(11):966-974.

31. Jacobson K, Fisher DL, Hoffman K, Tsoulas KD. Integrated cases section: A course designed to promote clinical reasoning in year 2 medical students. Teach Learn Med. 2010;22(4):312-316.

32. Chumley $\mathrm{H}$, Olney C, Usatine R, Dobbie A. A short transitional course can help medical students prepare for clinical learning. FAMILY MEDICINE-KANSAS CITY-. 2005;37(7):496.

33. Jacobs JCG, Bolhuis S, Bulte JA, Laan R, Holdrinet RSG. Starting learning in medical practice: An evaluation of a new introductory clerkship. Medical Teacher. 2005;27(5):408-414.

34. Liu C-H, Tang W-R, Weng W-H, Lin Y-H, Chen C-Y. The process of coping with stress by taiwanese medical interns: A qualitative study. BMC medical education. 2016;16(1):10.

35. Soo J, Brett-MacLean P, Cave MT, Oswald A. At the precipice: A prospective exploration of medical students' expectations of the pre-clerkship to clerkship transition. Adv Health Sci Educ Theory Pract. 2016;21(1):141-162.

36. Pitkala K, Mantyranta T. Professional socialization revised: Medical students' own conceptions related to adoption of the future physician's role--a qualitative study. Medical teacher. 2003;25(2):155-160.

37. Mezirow J. Perspective transformation. Adult education. 1978;28(2):100-110.

38. Yardley S, Westerman M, Bartlett M, Walton JM, Smith J, Peile E. The do's, don't and don't knows of supporting transition to more independent practice. Perspectives on medical education. 2018;7(1):8-22.

39. Wenger-Trayner E, Fenton-O'Creevy M, Hutchinson S, Kubiak C, Wenger-Trayner B. Learning in landscapes of practice: Boundaries, identity, and knowledgeability in practice-based learning: Routledge; 2014.

40. O'Brien BC, Battista A. Situated learning theory in health professions education research: A scoping review. Advances in Health Sciences Education. 2020;25(2):483-509.

41. Bauer TN, Erdogan B. Organizational socialization: The effective onboarding of new employees. In: Zedeck S. Apa handbooks in psychology ${ }^{\circledR}$, apa handbook of industrial and organizational psychology. Vol Vol. 3. Maintaining, expanding, and contracting the organization: American Psychological Association; 2011. 
42. Gruman JA, Saks AM, Zweig DI. Organizational socialization tactics and newcomer proactive behaviors: An integrative study. Journal of vocational behavior. 2006;69(1):90-104.

43. Dodgson JE. Reflexivity in qualitative research. Journal of Human Lactation. 2019;35(2):220-222.

44. Charmaz K. Constructing grounded theory: A practical guide through qualitative analysis: sage; 2006. 


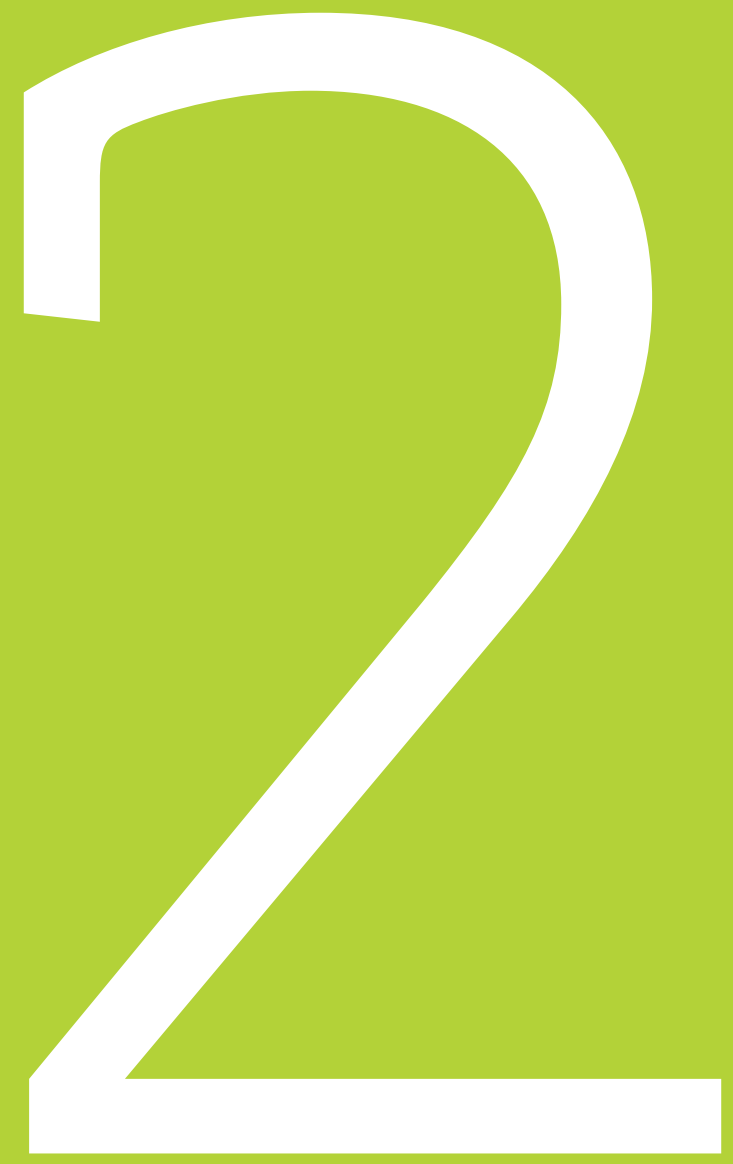




\section{Beyond the struggles: A scoping review on the transition to undergraduate clinical training}

\section{Published as:}

Atherley A, Dolmans D, Hu W, Hegazi I, Alexander S, Teunissen PW.

Beyond the struggles:

a scoping review on the transition to undergraduate clinical training.

Medical education. 2019 Jun;53(6):559-70. 


\section{ABSTRACT}

\section{Context}

The transition to clinical training within medical school is often seen as a struggle and students remain in distress despite numerous efforts to minimise threats. Efforts to change this may be misdirected if they are based on narrow conceptualisations of transitions. The authors conducted a scoping review to explore existing conceptual perspectives regarding the transition within medical school from pre-clinical training to clinical training to suggest a research agenda and practical implications.

\section{Methods}

Between October 2017 and February 2018 the authors searched PubMed, MEDLINE, ERIC, PsycINFO, Web of Science and CINAHL for English language literature with no date limits and retrieved 1582 articles; 45 were included in this review. Two reviewers independently screened articles and extracted data. Data were then charted, analysed and discussed with the research team.

\section{Results}

The transition to clinical training was often described negatively as 'difficult', 'a problem' and 'a struggle'. Our analysis found that researchers in medical education conducted studies on the transition to clinical training from three conceptual perspectives: educational; social, and developmental. Most research approached the transition to clinical training as a problem to be addressed from an educational perspective through transition to clerkship courses and curriculum innovations. Some research was conducted from a social perspective, focusing on building relationships. Regarding development, authors found a few articles highlighting opportunities for personal and professional development by nurturing transferrable learning strategies and reflection.

\section{Conclusions}

This review provides an empirical base on which future research can be built to better understand and support medical students' ability to navigate change. Finding new perspectives to approach the transition to clinical training could allow researchers to look beyond preparing students for struggles. 


\section{INTRODUCTION}

Medical professionals are repeatedly exposed to changes in contexts and responsibilities from undergraduate to postgraduate training as they traverse the medical education continuum. Medical training steers students through pre-clinical training, to clinical training, to being a newly practising doctor, to specialty training and ultimately to a consultant or specialist. This continuum is punctuated with prolonged, dynamic transition periods as a newcomer adjusts to a new environment. ${ }^{1-4}$ Changing from primarily being in a 'pre-clinical' classroom environment to mainly being in a 'clinical' patient-focused environment is the first of many transition periods that medical trainees will encounter once they have begun medical training and are on a trajectory to being a doctor. This scoping review will focus on medical students transitioning from preclinical to clinical training.

There is a large focus on increasing students' preparedness and reducing the gap in knowledge and skills between pre-clinical and clinical training. ${ }^{5-8} \mathrm{~A}$ previous systematic review found that many aspects related to perceived preparedness during the transition from pre-clinical to clinical training can be addressed in curricula. ${ }^{9}$ Such curricula changes include facilitating early patient contact ${ }^{10}$ and problem-based learning. ${ }^{11}$ These interventions try to reduce the gap between preclinical and clinical training, making the distinctions less apparent. However, despite these interventions, students still feel stressed and anxious, ${ }^{8,12,13}$ and as if they are 'thrown into the deep end'14 when entering the clinical environment.

A previous scoping review by Yardley et al. provides a practical approach to transitions in medical education by describing the 'dos, don'ts and don't knows' of supporting trainees towards progressive independence during medical education. Yardley's review proposes moving beyond student perceptions when evaluating the impact of any transition, ${ }^{3}$ and further suggests that the lack of outcomes beyond students's perceptions could 'have influenced the existent literature on the concept of transitions .....3 This suggestion is likely to refer to the current framing, and thus focus, of transitions in the literature and it remains unclear what this constitutes. Although this review by Yardley et al. yielded practical suggestions for improving support during transitions, it did not explore the conceptualisations of transitions innate in the current understanding of transitions in medical education literature. ${ }^{3}$

In a recent commentary on the transition to postgraduate residency, O'Brien suggests that perhaps something is missing from the way transitions in medical education are framed and proposes a shift to framing this transition as a transformative process as opposed to a problem. ${ }^{15}$ The transition to clinical training within medical school might 
also benefit from a similar reframing of how it is currently perceived and conceptualised in medical education. Analysing existing conceptualisations could shed light on what current framings of the transition to undergraduate clinical training help us to understand, and what these conceptualisations prevent us from recognising. Such a synthesis could support future research on the transition to undergraduate clinical training. The authors conduct this review on the assumption that different interpretations of what transitions are and how they should be addressed are likely to influence research and practice, and we seek to set a baseline understanding. We therefore conducted a scoping review of the published literature on the transition to undergraduate clinical training to identify the conceptual perspectives taken when addressing the transition to undergraduate clinical training, as well as simultaneously identifying gaps in these perspectives.

\section{METHODS}

We conducted a scoping review following five stages as described by Levac et al.: (i) identifying the research questions; (ii) identifying the relevant studies; (iii) study selection; (iv) charting the data, and (v) collating, summarising and reporting results. ${ }^{16}$ Peters et al. describe that

... beyond preceding systematic reviews, scoping reviews are independently used to explore broad areas to identify gaps in the literature, clarify key concepts and report on the types of evidence that address and inform practice...17

As such, scoping reviews are valuable for mapping the key concepts within a research area. ${ }^{18}$ Therefore, we conducted a scoping review in order to identify current conceptual perspectives taken in the literature regarding the transition to undergraduate clinical training and highlight gaps, in order to suggest a research agenda with some practical implications.

\section{Identifying the research question}

This scoping review focused on the following research question: How have researchers approached the transition within medical school from pre-clinical to clinical training and what are the gaps in these approaches? We did not seek to develop recommendations on how to improve current interventions relevant to this transition. 
Box 1: Search strategy for PubMed

transition[All Fields] AND (((("clinical clerkship"[MeSH Terms] OR "clinical preceptorship"[All Fields]) OR "clinical clerkship"[MeSH Terms]) OR "clinical rotation"[All Fields]) OR "preceptorship"[MeSH Terms]) AND ((("medical student"[All Fields] OR "undergraduate"[All Fields]) OR "medical school"[All Fields]) OR "clinical student"[All Fields])

$\mathrm{MeSH}=$ Medical Subject Headings

\section{Identifying relevant studies}

We determined the search strategy through team discussion and consulting the university librarian. We searched PubMed, MEDLINE, ERIC, PsycINFO, Web of Science and CINAHL. A sample search strategy for PubMed is seen in Box 1 below, which yielded 52 articles. We used no date limits and included articles published online ahead of print. We conducted the initial search on 26 October 2017 and issued citation alerts until 28 February 2018.

\section{Study selection}

EndNote X8 (Clarivate Analytics, Philadelphia, PA, USA) was used to download the bibliographic details of studies yielded from the database searches and duplicates were deleted. Researchers AA and SA independently screened article titles and abstracts to determine eligibility for full-text review against the inclusion criteria (Box 2). Any discrepancies were discussed until consensus. After this initial screening, AA and SA read full texts of articles to determine eligibility for inclusion. This scoping review included and excluded articles as per criteria in Box 2. Figure 1 shows a flowchart indicating this search and selection process. Our initial search was systematic in order to obtain a broad scope of the literature, with an aim to be inclusive in our review. Our scope of the literature yielded 1582 articles from six databases and 17 from reference screening and citation alerts. Following screening and full-text review, 45 articles were included in this review. 
Box 2: Inclusion and exclusion criteria for this scoping review

\section{Inclusion criteria:}

The following articles were included in this scoping review:

1) Published in English

2) Focused on medical students, trainees or junior doctors (NOT dental, pharmacy, physiotherapy, nursing or other professions)

3) Discussed the transition to clinical training by:

a. describing or evaluating a support strategy that assists new undergraduate students in their transition to clinical training,

b. describing students' experiences during this transition as this was thought to yield insight into useful support strategies.

4) Was a review article including an exploration of the transition into clinical training

5) Was a theoretical article including an exploration the transition into clinical training

\section{Exclusion criteria:}

The following articles were excluded from this scoping review:

1) Perspective articles not substantiated on theory.

2) Those without full text.

3) Those exploring the transition to a single, specific undergraduate clerkship that was not the first clerkship as students experiencing a second clerkship would have some previous full-time experience within the clinical environment

4) Those evaluating transitions in patient care.

\section{Charting the data}

The first author (AA) developed a data charting form (see Appendix S1) to extract data, including author, publication year, journal, study aim, study design, theoretical framework, data collection methods, year of data collection, summary of key findings, description of a specific support strategy and relevant references. Another author (SA) reviewed full-text articles against the data extraction to check for completeness and any discrepancies were discussed. The extraction process was iterative and was refined based on discussions between the first author (AA) and the rest of the research team (DD, WH, IH, SA and PWT).

\section{Collating, summarising and reporting results}

The first author (AA) thematically analysed the data with SA and extracted data to answer the research question and meet the objectives of this scoping review. SA and AA discussed findings, which were then discussed with the rest of the research team (DD, WH, IH and PWT). ATLAS.ti Version 8.1.29.0 (ATLAS.ti Scientific Software Development $\mathrm{GmbH}$, Berlin, Germany) was used to help manage articles and any coding and synthesis of articles. This process was also iterative and bolstered by team discussions. Our team consists of a combination of clinicians, medical educators with doctorates and a current $\mathrm{PhD}$ candidate in medical education with previous research experience. Our syntheses 


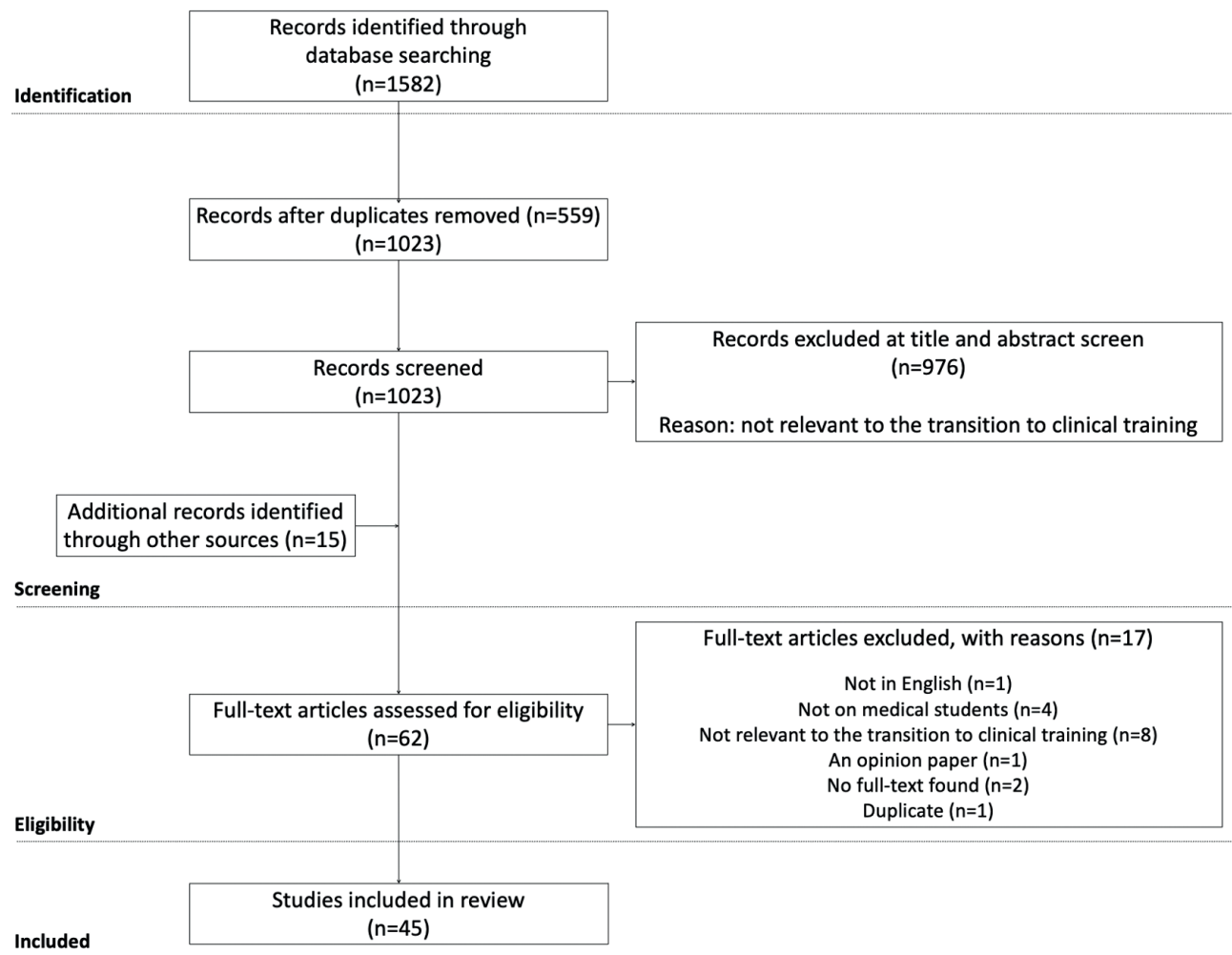

Figure 1: Flowchart of the search process and results for this scoping review

of researchers' perspectives were not explicitly described by researchers but instead represent our interpretations and reanalysis of existing research.

\section{RESULTS}

\section{Descriptive summary}

Included studies were from the USA $(n=21)$, Europe $(n=11)$, UK $(n=8)$, Canada $(n=3)$ and Australia $(n=2)$. There were 12 qualitative studies,10,11,14,19-27 11 cross-sectional surveys,6-8,13,28-34 eight descriptive case studies ${ }^{5,35-41}$ (two of which were related, using the same participants and intervention), ${ }^{36,37}$ seven longitudinal studies, ${ }^{42-48}$ three descriptive comparative studies, ${ }^{12,49,50}$ three review papers ${ }^{1,3,9}$ and one concept paper. ${ }^{51}$

\section{Conceptual perspectives}

Our analysis found that researchers in medical education conducted studies on the transition to clinical training from three conceptual perspectives: educational, social and developmental. We do not suggest that these synthesised categories are mutually 
exclusive, but indicate the main focus of the articles in these categories. Allocation to a category is thus based on the implicit views of the transition from pre-clinical to clinical training inherent in researchers' discourse, interventions, choices of outcomes and suggestions. We will describe what we mean by these three perspectives, followed by details on the studies that were conducted from each perspective and what each one reveals regarding the transition to clinical training.

Box 3 shows a short description of our interpretations of these perspectives. Table 1 summarises these perspectives with regard to associated terminology, strategies used to approach the transition and annotations on a study that exemplifies each perspective.

Box 3: Three conceptual perspectives used to approach the transition from pre-clinical to clinical training

\section{Educational perspective}

Implicit in this perspective was how researchers addressed students' struggles by trying to narrow the gap between pre-clinical and clinical training often through courses and curriculum innovations to facilitate learning knowledge and skills.

\section{Social perspective}

Implicit in this perspective was how researchers addressed undergraduate students' struggles when transitioning from pre-clinical to clinical training by focusing on relationships and developing a nurturing learning environment53 between staff and students and between students themselves.

\section{Developmental perspective}

Implicit in this perspective was how researchers recognized that undergraduate students will always have challenges when transitioning from pre-clinical to clinical training, but aimed to empower them by facilitating reflection and transferrable learning strategies.

\section{Educational perspective}

Researchers often portrayed the transition to clinical training negatively, describing it as difficult, $6,39,50$ stressful, $8,12,13,19,21,23,28,35,37,47,49$ anxiety generating ${ }^{8,12,13,32-34,36,37}$ and a struggle.,26,27,44 Some studies started from a stance that there was a need to eliminate a variety of struggles, including students: feeling like they lacked the required knowledge and skills, ${ }^{6,11,13,19,27,34}$ feeling unprepared, ${ }^{11,28,30,32}$ feeling burdened by the demands of clinical training, ${ }^{11,19,28,42}$ not meeting faculty members' expectations, ${ }^{9,33}$ and stressed by frequent changes in context. ${ }^{27}$ 


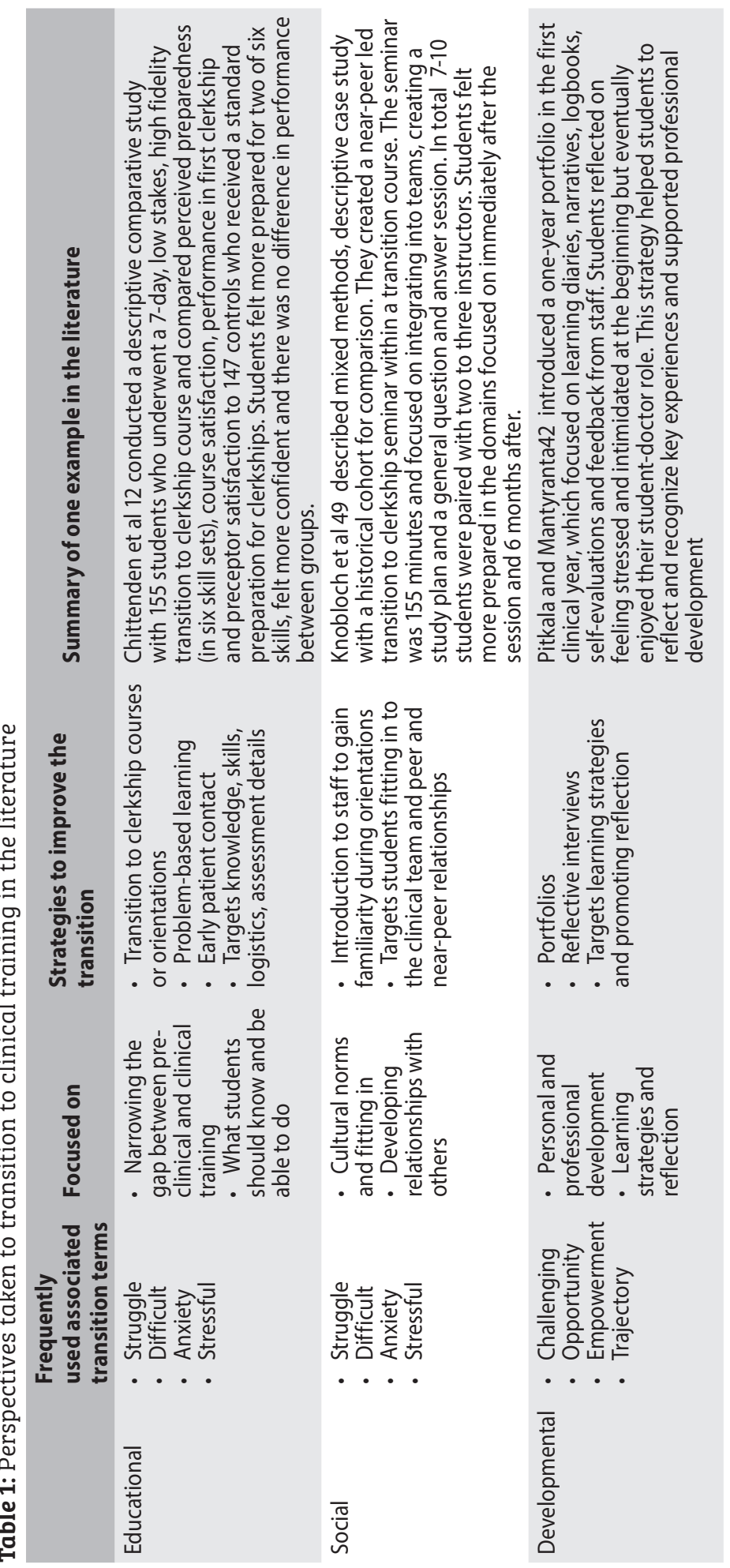


The tendency to address a gap in knowledge or skills led to researchers focusing on preparing students and reducing this gap. Researchers sought to 'prepare students to excel as learners in clinical settings' ${ }^{\prime 29}$ by strengthening 'students' basic proficiency in oral patient presentations ... basic skills in phlebotomy, arterial blood gases and suturing ....12 Some research assumes that the aforementioned struggles will 'stifle progress. ${ }^{28,34}$ This assumption is not supported by Van Hell et al., ${ }^{6}$ who showed that perceived difficulty with the transition did not predict performance. Conceptualising the transition to clinical training from an educational perspective has influenced the creation of strategies aimed to 'ease students' transition from the pre-clinical to clinical years' ${ }^{42}$ These strategies include the development of specific transition to clerkship courses $^{5,7,8,12,35-37,39,40,42,49,50}$ and evaluating pre-clinical curriculum innovations and their impact on students' transition experiences. $6,10,11,14,22-24,28,29,32,33,46$ Curriculum innovations in the literature include pre-clinical problem-based learning (PBL) curricula, 6,11,24,28,29,32 creating space for early patient contact ${ }^{10,14,33}$ and development of longitudinal integrated clerkships (LIC) during clinical training. ${ }^{22}$

The aforementioned studies evaluated the transition to clinical training and relevant interventions with outcomes such as: student satisfaction with a particular strategy, ${ }^{5,12,37,39,40}$ measuring impact on anxiety ${ }^{12}$ and confidence ${ }^{35,42}$ and calculating change in knowledge, skills or behaviour. ${ }^{12,35-37,39}$ These outcomes all reflect a focus on measuring the educational impact of a transition and related interventions. Some articles showed that transition-toclerkship courses and curriculum innovations increased students' perceived preparedness for clinical training, ${ }^{12,39,49}$ increased confidence, ${ }^{9,29,35,42}$ reflection and transferrable learning strategies. reduced anxiety ${ }^{12}$ and motivated students. ${ }^{24}$ However, some students still struggled with socialisation. ${ }^{10,23}$

Most literature on the transition to clinical training was from an educational perspective, which sees the transition as a struggle due to the knowledge and skill deficits that students have. Consequently, interventions were designed to address these deficits with pre-clinical courses and inductions. As a result, studies focus on outcomes such as student satisfaction and perceived preparedness, with some showing increased preparedness and student satisfaction. We recognised a second perspective with a shared concern for students' struggles when entering clinical training but a different approach to managing their difficulties.

\section{Social perspective}

Again, researchers described the transition to clinical training in negative terms and highlighted a need to eliminate a variety of struggles, including students: trying to fit in with insiders, $32,46,48$ feeling intimidated by others, ${ }^{32,34}$ being unsure of their role, ${ }^{9,27}$ and learning the cultural norms of the clinical environment. ${ }^{27}$ Studies suggest that 
students were 'unfamiliar with learning within the workplace and uncertain about how to navigate and engage within teams and culture they have not come to understand'.43 As a result, students often placed a significant focus on fitting in with the clinical team as opposed to learning. ${ }^{46}$

Addressing students'integration led to a focus on peer-peer and peer-team relationships. Researchers thought it was important to make explicit 'the hidden knowledge that students need to become effective team members ${ }^{\prime 25}$ and to create strategies that would 'describe the roles and expectations ... routines and logistics' relevant to the clinical environment. ${ }^{12}$ It therefore was important to facilitate meaningful interactions and relationship building with others. ${ }^{25,43,48}$ Examples of these social strategies included initiating peer groups, ${ }^{25}$ nearpeer teaching sessions, ${ }^{48}$ facilitating students sharing experiences, ${ }^{43}$ and creating peer learning communities. ${ }^{45}$ Additionally, to promote student- staff relationships in the clinical environment, some researchers reported on the use of multidisciplinary approaches to educational inductions and including residents in these orientations. ${ }^{12,39}$ Regarding measuring outcomes, increased social support was likely to reduce stress ${ }^{19}$ and, in one study, increased students' perceptions of preparedness as it related to integrating into the clinical team. ${ }^{48}$

Literature on the transition to clinical training conducted from a social perspective still sees the transition as a struggle as a result of students trying to fit into the new environment and not being familiar with existing cultural norms and how to build relationships. The approach was therefore to develop activities that familiarise students with others (professionals and peers) in the clinical environment. As a result, studies focused on outcomes related to fitting into the clinical team.

This social perspective alone does not seem to recognise the importance of students' selfawareness and reflection to minimise the impact that negative role modelling could have on novice students. We recognised a third conceptualisation of the transition to clinical training that differs from the first two in that it doesn't problematise students' struggles.

\section{Developmental perspective}

Unique to this perspective, researchers reported the transition to clinical training as challenging. ${ }^{1,5,7,9,36-38,43,44,50}$ This terminology differs to that of the other two perspectives and could be considered a positive cognitive appraisal by researchers highlighting the potential for students' growth. ${ }^{52,53}$ Research within this perspective allows the discussion to shift away from a stance of minimising particular struggles that students experience during the transition to clinical training and towards recognising the need for students to be able to cope with change. 
Conceptualising the transition to clinical training from a developmental perspective has led to the creation of strategies aimed at empowerment. By contrast with researchers' focus on problems from educational and social perspectives, when taking a developmental perspective, researchers mentioned the desire 'to empower third-year undergraduate medical students to recognize learning opportunities in their clinical placements and to proactively use them to develop their understanding and practice.43 Empowering students promotes personal and professional development by optimising learning strategies and encouraging reflection..$^{38,41,43,44,50}$

The literature provides some examples of how researchers approached development during the transition to clinical training. The transition to clinical training requires that students adapt their learning strategies to learn in a self-directed way but this does not automatically develop. ${ }^{44}$ Additionally, the clinical environment could have a negative impact on self-regulated learning skills ${ }^{44}$ by increasing extrinsic goal orientation when decreasing metacognitive self-regulation. ${ }^{44}$ Optimising clinical learning strategies is therefore important for new clinical students. Additionally, reflection in the form of portfolios ${ }^{41}$ and narratives towards the end of pre-clinical training ${ }^{38}$ facilitated students recognising key experiences, ${ }^{38,39,41}$ promoted professional development ${ }^{41}$ and reframed their experiences towards becoming the type of doctor they wanted to be. ${ }^{38}$

There was comparatively less research carried out from a social and developmental perspective. However, researchers are increasingly recognising a need to explore the opportunities that the transition to clinical training can provide. ${ }^{1,30,44}$

\section{DISCUSSION}

This scoping review demonstrates that the transition from pre-clinical to clinical training is conceptualised from three perspectives: educational, social and developmental. Most research was undertaken from an educational perspective as compared to social and developmental approaches. Here we explore what these three perspectives say and do not say about the transition to clinical training. Then, we will briefly describe practical implications of our findings and suggest a research agenda.

Having an educational perspective primarily focuses researchers on reducing the gap between preclinical and clinical training and produces a desire to increase students' knowledge and skills so that students experience a smaller gap between these training stages. In this light, a'good'transition from an educational perspective, is likely to be one where students feel prepared, have all the knowledge and skills required to start clinical training and do not feel overwhelmed by the amount of learning to cover. However, it is not enough for students to feel prepared ${ }^{3,54}$ nor should we expect that we can adequately 
prepare them for the dynamics of a new environment, which itself is unstable. This is not to suggest that educational preparation is not important; however, this is not the sole factor. Kilminster described transitions in postgraduate training to be critically intensive learning periods. ${ }^{54}$ Even though the concept was in a postgraduate setting, using this conceptualisation within medical school is likely to be useful for minimising the focus on preparedness and, instead, promoting the transition as a dynamic period in which students learn and establish relationships.

A social perspective on the transition to clinical training fills the gaps in taking a solely educational perspective by reducing the expectation that students need to be knowledgeable and skilled, thus allowing a focus on building relationships with staff, peers or near-peers. Cultivating a nurturing medical environment where students are not intimidated can encourage team building and student engagement. ${ }^{55}$ Most research has focused on targeting students and very rarely explicitly focuses on training staff to help students to integrate within clinical teams. ${ }^{39,50}$ Students still experience academic bullying and negative role modelling during the transition to clinical training ${ }^{56,57}$, so it is likely that the clerkship culture and environment need to adapt with newly arriving clinical students to create a new community functioning with newcomers. This would require the newcomers to be integrated into the daily work of the environment, which could promote learning and motivation and could even add value to the community. ${ }^{58}$ A 'good' transition from a social perspective is likely to be one where students integrate into the community of practice of the clerkship environment and gain legitimate access to learning opportunities through participation. This perspective, however, might be overlooking the usefulness of social support being used alongside self-reflection to help students decipher which behaviours should be imitated..$^{59}$

A developmental perspective fills gaps in both the educational and social perspectives on the transition to clinical training by promoting student reflection on learning and integration experiences. Taking this developmental perspective empowers students and provides them with the tools for ownership of their learning and transition experience through reflection and optimising transferrable learning skills. Transitions provide opportunities to offer proactive and reactive support and learn coping skills, which are imperative for future learning as medical trainees. ${ }^{60}$ Amongst interns (recent medical school graduates), Liu et al. ${ }^{61}$ found that using selfdirected learning as a coping strategy led to motivation and learning as compared to emotionbased strategies such as avoidance. This highlights that sometimes 'struggles' could serve as motivation for learning. ${ }^{61}$ Proactive support strategies, as opposed to reactive strategies occurring when difficulties already exist, are likely to be particularly useful to help trainees learn to deal with stressful change, which is highly likely in their career. ${ }^{60}$ Promoting developmental skills such as reflection, self-regulated learning skills and other skills such as resilience, could help students adapt to change. ${ }^{2,3,60} \mathrm{~A}$ 'good' transition from a developmental 
perspective might start from a stance where researchers understand that the transition is challenging but can be harnessed to provide motivation for learning.

We have illustrated how a particular perspective could influence approaches, outcomes and perceptions of what is a'good transition'. In practice, it could be beneficial to combine elements of educational, social and developmental perspectives. This combination could result in students' education prior to the transition period being appropriate, so they can integrate socially and utilise developmental competencies of reflection and resilience.

\section{A new research agenda}

Our findings highlight areas that may be overlooked by research that adopts single conceptualisations of the transition to clinical training. There is comparatively less research from social and developmental perspectives. We suggest that research from a social or developmental perspective could still be useful in order to inform combined social and developmental approaches to the transition to clinical training. Research from a social perspective could ask: How do relationships with others aid students' transition experiences and learning when entering the clinical environment? From a developmental perspective, it could be useful to understand: Which procedures for reflection during the transition would be most beneficial to students' experiences? Lastly from a combined perspective one might explore: How could reflection influence students' relationships during the transition to clinical training? Methodologically, longitudinal research might be informative from a developmental perspective to allow researchers to understand the process of professional and personal growth during challenging transition periods such as entering clinical training.

Existing research rarely showed researchers explicitly reflecting on their potential biases and assumptions when conducting research on the transition to clinical training. Future research could benefit from researchers critically considering from which perspective they are approaching the transition to clinical training and the impact this might have on their methodology, findings and interpretations.

Combining researcher reflexivity with underpinning empirical research with theory could be powerful next steps in researching the transition to clinical training. For example, stressful experiences can trigger transformative learning, which Mezirow suggests requires experiences, critical reflection and dialogue with others in order to transform individuals' existing perspectives of themselves, their beliefs and their behaviours. ${ }^{62}$ Future researchers could conceptualise the transition to clinical training as a transformational experience, thereby combining educational, social and developmental perspectives. O'Brien posits that medical educators should recognise that the transition is 'an adaptable learning process' ${ }^{15}$ and speaks to the potential for 
transformative learning ${ }^{62}$ during the postgraduate transition to residency; this could be transferrable to medical school experiences, ${ }^{3}$ as well as priming postgraduates for future careers. Future research could, therefore, explore what a transformative transition would look like and how this could be evaluated. Focusing on a new conceptualisation of the transition to clinical training - being a transformative experience - could allow new outcomes for research in this area to be considered and researchers might decrypt what a successful transition might look like, what outcomes are important, how to measure them, and effective ways to support students' transitions.

This scoping review also provides evidence that the scales currently tip towards the fact that researchers consider the transition to clinical training to be a threat. Lazarus and Folkman suggest that feelings of threat and challenge may occur simultaneously as students transition into clinical training and, although related, challenge and threat may not be on the same continuum, but instead are separate constructs. ${ }^{53}$ There is much research on the transition as a threat but less on transition as a developmental challenge.

\section{Limitations}

Additional databases may have yielded more articles. Non-English articles might have been overlooked. Additionally, we made the decision to exclude grey literature. The focus of our scoping review was on the scholarly conceptualisations of the phenomenon of transitioning to clinical training. Our results may be helpful for reflecting on the grey literature as well and we suspect there is a strong focus on the educational perspective, for example, through educational innovation reports. The first author (AENA) has had an interest in transitions for over 5 years, which might have led to the development of preconceived notions surrounding the transition to clinical training and influenced interpretations of data. However, discussions with the research team are likely to have reduced this bias.

\section{CONCLUSIONS}

This scoping review provides insight into perspectives found in the literature on the transition from pre-clinical to clinical training within medical school. This transition is primarily seen as a maladaptive struggle, with many researchers addressing the transition from an educational perspective by focusing on increasing preparedness with relevant knowledge and skills. However, the challenge associated with the transition to clinical training can be motivating and be an important, critically intensive learning period for new clinical students. Future research on the transition to clinical training from social and developmental perspectives (individual and combined) is likely to stimulate opportunities to advance students' adaptations to the clinical environment. 


\section{REFERENCES}

1. Teunissen PW, Westerman M. Opportunity or threat: the ambiguity of the consequences of transitions in medical education. Med Educ 2011;45 (1):51-9.

2. Gordon L, Jindal-Snape D, Morrison J, Muldoon J, Needham G, Siebert S, Rees C. Multiple and multidimensional transitions from trainee to trained doctor: a qualitative longitudinal study in the UK. BMJ Open 2017;7 (11):e018583.

3. Yardley S, Westerman M, Bartlett M, Walton JM, Smith J, Peile E. The do's, don't and don't knows of supporting transition to more independent practice. Perspect Med Educ 2018;7 (1):8-22.

4. Jindal-Snape D, Rienties B. Understanding multiple and multi-dimensional transitions of international higher education students. In: Jindal-Snape D and Rienties B, eds. Multi-dimensional Transitions of International Students to Higher Education: New Perspectives on Learning and Instruction. London: Routledge 2016;1-16.

5. Sakai DH, Fong SF, Shimamoto RT, Omori JS, Tam LM. Medical school hotline: transition to clerkship week at the John A. Burns School of Medicine. Hawaii J Med Public Health 2012;71 (3):81-3.

6. Van Hell EA, Kuks JB, Schonrock-Adema J, van Lohuizen MT, Cohen-Schotanus J. Transition to clinical training: influence of pre-clinical knowledge and skills, and consequences for clinical performance. Med Educ 2008;42 (8):830-7.

7. O'Brien BC, Poncelet AN. Transition to Clerkship Courses: preparing students to enter the workplace. Acad Med 2010;85 (12):1862-9.

8. Poncelet A, O'Brien B. Preparing medical students for clerkships: a descriptive analysis of transition courses. Acad Med 2008;83 (5):444-51.

9. Surmon L, Bialocerkowski A, Hu W. Perceptions of preparedness for the first medical clerkship: a systematic review and synthesis. BMC Med Educ 2016;16:89.

10. Yardley S, Brosnan C, Richardson J. The consequences of authentic early experience for medical students: creation of metis. Med Educ 2013;47 (1):109-19.

11. Prince $K$, van de Wiel MJ, Scherpbier A, van der Vleuten CPM, Boshuizen HPA. A qualitative analysis of the transition from theory to practice in undergraduate training in a PBL-Medical School. Adv Health Sci Educ 2000;5 (2):105-16.

12. Chittenden EH, Henry D, Saxena V, Loeser H, O'Sullivan PS. Transitional clerkship: an experiential course based on workplace learning theory. Acad Med 2009;84 (7):872-6.

13. Sarikaya O, Civaner M, Kalaca S. The anxieties of medical students related to clinical training. Int J Clin Pract 2006;60 (11):1414-8.

14. Dornan T, Bundy C. What can experience add to early medical education? Consensus survey BMJ 2004;329 (7470):834.

15. O'Brien BC. What to do about the transition to residency? Exploring problems and solutions from three perspectives. Acad Med 2018;93 (5):681-4.

16. Levac D, Colquhoun H, O'Brien KK. Scoping studies: advancing the methodology. Implement Sci 2010;5:69.

17. Peters MD, Godfrey CM, Khalil H, Mclnerney P, Parker D, Soares CB. Guidance for conducting systematic scoping reviews. Int J Evid Based Healthc 2015;13 (3):141-6.

18. Arksey H, O'Malley L. Scoping studies: towards a methodological framework. Int J Soc Res Methodol 2005;8 (1):19-32.

19. Radcliffe $\mathrm{C}$, Lester $\mathrm{H}$. Perceived stress during undergraduate medical training: a qualitative study. Med Educ 2003;37 (1):32-8. 
20. Babaria P, Abedin S, Nunez-Smith M. The effect of gender on the clinical clerkship experiences of female medical students: results from a qualitative study. Acad Med 2009;84 (7):859-66.

21. Small RM, Soriano RP, Chietero M, Quintana J, Parkas V, Koestler J. Easing the transition: medical students' perceptions of critical skills required for the clerkships. Educ Health 2008;21 (3):192.

22. Konkin DJ, Suddards C. Students' experiences of role, relationships and learning in two clerkship models. Med Educ 2017;51 (5):490-7.

23. Godefrooij MB, Diemers AD, Scherpbier AJ. Students' perceptions about the transition to the clinical phase of a medical curriculum with preclinical patient contacts; a focus group study. BMC Med Educ 2010;10:28.

24. White CB. Smoothing out transitions: how pedagogy influences medical students' achievement of selfregulated learning goals. Adv Health Sci Educ 2007;12 (3):279-97.

25. Chou CL, Teherani A, Masters DE, Vener M, Wamsley M, Poncelet A. Workplace learning through peer groups in medical school clerkships. Med Educ Online 2014;19:25809.

26. Berkhout JJ, Helmich E, Teunissen PW, van der Vleuten CPM, Jaarsma ADC. How clinical medical students perceive others to influence their selfregulated learning. Med Educ 2017;51 (3):269-79.

27. O'brien B, Cooke M, Irby DM. Perceptions and attributions of third-year student struggles in clerkships: do students and clerkship directors agree? Acad Med 2007;82 (10):970-8.

28. Prince KJ, Boshuizen HP, van der Vleuten CP, Scherpbier AJ. Students' opinions about their preparation for clinical practice. Med Educ 2005;39 (7):704-12.

29. Shacklady J, Holmes E, Mason G, Davies I, Dornan T. Maturity and medical students' ease of transition into the clinical environment. Med Teach 2009;31 (7):621-6.

30. Bosch J, Maaz A, Hitzblech T, Holzhausen Y, Peters H. Medical students' preparedness for professional activities in early clerkships. BMC Med Educ 2017;17 (1):140.

31. Windish DM, Paulman PM, Goroll AH, Bass EB. Do clerkship directors think medical students are prepared for the clerkship years? Acad Med 2004;79 (1):56-61.

32. Hayes K, Feather A, Hall A, Sedgwick P, Wannan G, Wessier-Smith A, Green T, McCrorie P. Anxiety in medical students: is preparation for full-time clinical attachments more dependent upon differences in maturity or on educational programmes for undergraduate and graduate entry students? Med Educ 2004;38 (11):1154-63.

33. Wenrich M, Jackson MB, Scherpbier AJ, Wolfhagen IH, Ramsey PG, Goldstein EA. Ready or not? Expectations of faculty and medical students for clinical skills preparation for clerkships. Med Educ Online 2010;15:5295.

34. Moss F, McManus I. The anxieties of new clinical students. Med Educ 1992;26 (1):17-20.

35. Jacobson K, Fisher DL, Hoffman K, Tsoulas KD. Integrated cases section: a course designed to promote clinical reasoning in year 2 medical students. Teach Learn Med 2010;22 (4):312-6.

36. Taylor JS, George PF, MacNamara MM, Zink D, Patel NK, Gainor J, Dollase RH. A new clinical skills clerkship for medical students. Fam Med 2014;46 (6):433-9.

37. George P, MacNamara MM, Gainor J, Taylor JS. An integrated virtual family curriculum to introduce specialty-specific clinical skills to rising third-year medical students. Teach Learn Med 2013;25 (4):342-7.

38. Soo J, Brett-MacLean P, Cave MT, Oswald A. At the precipice: a prospective exploration of medical students' expectations of the pre-clerkship to clerkship transition. Adv Health Sci Educ Theory Pract 2016;21 (1):141-62.

39. Jacobs JCG, Bolhuis S, Bulte JA, Laan R, Holdrinet RSG. Starting learning in medical practice: an evaluation of a new introductory clerkship. Med Teach 2005;27 (5):408-14.

40. Skhal KJ. A full revolution: offering 360 degree library services to clinical clerkship students. Med Ref Serv Q 2008;27:249-59. 
41. Pitkala K, Mantyranta T. Professional socialization revised: medical students' own conceptions related to adoption of the future physician's role-a qualitative study. Med Teach 2003;25 (2):155-60.

42. Van Gessel E, Nendaz MR, Vermeulen B, Junod A, Vu NV. Development of clinical reasoning from the basic sciences to the clerkships: a longitudinal assessment of medical students' needs and selfperception after a transitional learning unit. Med Educ 2003;37 (11):966- 74.

43. McKee A, Markless S. Using action learning sets to support students managing transition into the clinical learning environment in a UK medical school. Action Learn 2017;14 (3):275-85.

44. Cho KK, Marjadi B, Langendyk V, Hu W. Medicalstudent changes in self-regulated learning during the transition to the clinical environment. BMC Med Educ 2017;17:59.

45. Dunham L, Dekhtyar M, Gruener G, CichoskiKelly E, Deitz J, Elliott D, Stuber ML, Skochelak SE. Medical student perceptions of the learning environment in medical school change as students transition to clinical training in undergraduate medical school. Teach Learn Med 2017;29 (4):383-91.

46. Balmer DF, Richards BF, Varpio L. 'How students experience and navigate transitions in undergraduate medical education: an application of Bourdieu's theoretical model': erratum. Adv Health Sci Educ Theory Pract 2015;20 (4):1073-85.

47. Compton MT, Carrera J, Frank E. Stress and depressive symptoms/dysphoria among US medical students results from a large, notionally representative survey. J Nerv Ment Dis 2008;196 (12):891-7.

48. Knobloch A, Ledford C, Wilkes S, Saperstein A. The impact of near-peer teaching on medical students' transition to clerkships. Fam Med 2018;50 (1):58-62.

49. Chumley H, Olney C, Usatine R, Dobbie A. A short transitional course can help medical students prepare for clinical learning. Fam Med 2005;37 (7):496-501.

50. Hoffman M, Cohen-Osher M. The one minute learner: evaluation of a new tool to promote discussion of medical student goals and expectations in clinical learning environments. Fam Med 2016;48 (3):222-5.

51. Holmes CL, Harris IB, Schwartz AJ, Regehr G. Harnessing the hidden curriculum: a four-step approach to developing and reinforcing reflective competencies in medical clinical clerkship. Adv Health Sci Educ Theory Pract 2015;20 (5):1355-70.

52. Simmons BL, Nelson DL. Eustress at work: extending the holistic stress model. In Nelson DL and Cooper CL, eds. Positive Organizational Behavior. London:SAGE Publications Ltd 2007;40-53.

53. Lazarus RS, Folkman S. Stress, Appraisal, and Coping. New York, NY: Springer 1984.

54. Kilminster S, Zukas M, Quinton N, Roberts T. Preparedness is not enough: understanding transitions as critically intensive learning periods. Med Educ 2011;45 (10):1006-15.

55. Benbassat J. Undesirable features of the medical learning environment: a narrative review of the literature. Adv Health Sci Educ Theory Pract 2013;18 (3):527-36.

56. Tsui YY, Rice J, Pitzer M. Boxed in: lessons from the margins of medical student comics. Acad Med 2017;92 (12):1696.

57. Green MJ, George DR. Commentary on boxed in: lessons from the margins of medical student comics. Acad Med 2017;92 (12):1696.

58. Lave J, Wenger E. Situated Learning: Legitimate Peripheral Participation. Cambridge, UK: Cambridge University Press 1991

59. Benbassat J. Role modeling in medical education: the importance of a reflective imitation. Acad Med 2014;89 (4):550-4.

60. Sandars J, Patel R, Steele H, McAreavey M. Developmental student support in undergraduate medical education: AMEE Guide No. 92. Med Teach 2014;36 (12):1015-26.

61. Liu C-H, Tang W-R, Weng W-H, Lin Y-H, Chen C-Y. The process of coping with stress by Taiwanese medical interns: a qualitative study. BMC Med Educ 2016;16:10.

62. Mezirow J. Perspective transformation. Adult Educ 1978;28 (2):100-10. 
Appendix S1. Data charting form.

1. Author(s):

2. Year of publication:

3. Journal:

4. Study aim:

5. Study design:

6. Theoretical framework used for methods or to interpret results:

7. Data collection methods:

8. Year of data collection

9. Summary of key findings:

10. Description of a specific support strategy:

11. References that could be included: 


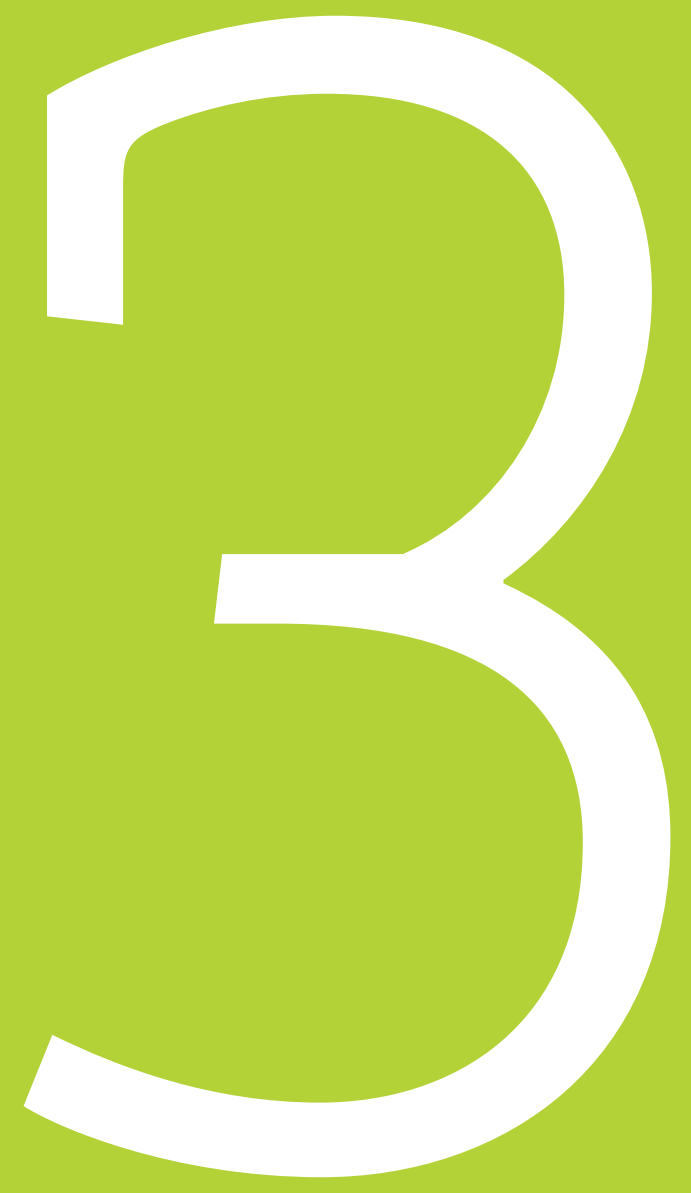




\section{Journey to becoming: Exploring students' lived reality and identity formation across the transition to clinical training}




\section{ABSTRACT}

Transitions are critical periods that can lead to growth and/or distress. Transitions are a sociocultural process and sociocultural approaches to learning can unlock the importance of identity development as a part of learning. Thus far, student identity formation (as opposed to professional identity formation) is not well explored. We aimed to explore how students narrate their navigation of the transition from preclinical to clinical training and especially their student identity development. Nine $2^{\text {nd }}$ year students generated 61 entries comprising of audio-diary (or typed) reflections over nine months (starting three months before clinical clerkships began) and two interviews. We used research poems (transcripts reframed as poetry) to help us construct a meaningful, emotive elicitation of our longitudinal data and analysed data using sensitising concepts from Wenger's modes of identification: engagement, imagination and alignment. Students described their transition as a journey filled with positive and negative emotions and uncertainty about their current and future career. Students navigated the transition using three mechanisms: 1)becoming more engaged through taking charge, 2)shaping their image of self through engagement and finding role models; and 3)learning to flexibly adapt to clerkship norms by managing expectations and adopting a journey mindset. Students largely accepted the ups and downs they experienced and noted that reflecting in this study was beneficial to their experiences. Thus, instead of seeking smooth transitions, transitions should be lived, reflected on and supported. In so doing, we can legitimise the student identity as they slowly develop their professional identities in a supported fashion. 


\section{INTRODUCTION}

Transitions are critical periods that can lead to growth and/or distress ${ }^{1-6}$. Transitions in medical training are boundary-crossing periods- e.g. when new clinical students enter a landscape with unique communities in each clerkship experience ${ }^{7}$. When medical students begin clerkships (also called placements or rotations), this inevitable change can be confronting; students perceive they lack the required knowledge to function in new environments and can struggle with building relationships and learning clerkship norms ${ }^{8,9}$. Most institutions try to 'smoothen' this transition by preparing students for a new phase via transition courses to address knowledge and skill gaps ${ }^{10}$. Increasingly, researchers urge educators to acknowledge and address the social and developmental aspects of transitions $\mathbf{s}^{1,6-8,11}$.

Sociocultural approaches to learning in health professions education are increasing, recognising that learning is also a matter of socialising into one's environment ${ }^{12}$. Wenger and others go further to highlight that developing an identity is also an integral part of learning ${ }^{13-15}$, thereby recognising the developmental aspects at play when newcomers navigate change ${ }^{1,7,12,14}$. Wenger-Trayer describes three modes of identification that describe how newcomers develop an identity as they participate in a new learning environment-engagement, imagination and alignment ${ }^{7}$. Engagement relates to the extent to which a newcomer is included in every-day practice. Imagination fosters the newcomer's thoughts of self in the past, present and future within the wider world, and alignment considers how a newcomer connects to existing perceptions, norms and competence in a new learning and working space ${ }^{7}$. Importantly, a students' identity is separate and distinct from the professional identity they are ultimately striving for ${ }^{6,17}$. Yet, most health professions education literature is skewed toward exploring professional identity formation leaving a gap in what student identity formation looks like. We however do know that social interactions with others is critical to students' identity formation ${ }^{17,18}$.

Through socialisation, identity is formed ${ }^{17}$. Therefore, by exploring the socialisation of students as they transform from lay public to a professional ${ }^{17}$, we can gain insight into students' developing identities. We believe that a transition is a social and developmental process ${ }^{1}$ and we were interested in how students narrated their lived reality of navigating the transition from pre-clinical to clinical training and their process of identification during this time. By understanding students' lived realities of navigating new environments and how they experience their developing identities effective support transition solutions can be suggested. ${ }^{11,16}$. 


\section{METHOD}

This was a qualitative longitudinal study using Wenger's modes of identification as a sensitising concept. We operated with an interpretivist paradigm assuming there is no single truth, that reality is socially constructed and is interpreted in different ways ${ }^{19}$. Within this paradigm, reality is assumed to be accessible through language and shared meaning ${ }^{20}$. Our methodology was narrative inquiry. Narrative inquiry is a way of understanding experiences ${ }^{21}$ and allowed us access to participants' language and meaning-making processes as they narrated and made sense of their lived reality ${ }^{22,23}$. We invited medical students to record audiodiary reflections as they transitioned from the pre-clinical to the clinical environment. We also interviewed them twice to expand on audiodiary content. Further, we used research poems - transcripts reframed as poetry ${ }^{24}$ - in our analysis procedures and to re-story participants' narratives. In so doing, we preserved participants' emotion in their narratives and privileged the longitudinal nature of our data.

\section{Participants}

We conducted this study within a five-year medical programme at an Australian university where students spend two years in primarily classroom-based education and then transition to three years in rotation-based clerkships/placements/attachments (lasting between 4 and 10 weeks).

AA asked all $2^{\text {nd }}$ year undergraduate medical students, soon commencing $3^{\text {rd }}$ year clerkships, to participate in this study during scheduled educational sessions and via social media pages. AA also placed flyers in populated physical locations. We enrolled ten participants. To be included, students needed to have a smart phone. One female student dropped out prior to any active study participation, while still in their $2^{\text {nd }}$ year, due to anticipated study burden. We followed nine participants (see Table 1) from preclinical training as they experienced three to four clerkships (e.g. Emergency Medicine, Internal Medicine and Colorectal Surgery, among others). In this paper, we replace names with pseudonyms and avoid identifying descriptions in quotes. Our participants came from backgrounds including: Malaysian, middle eastern, Indigenous, Indian, Chinese, Caucasia and Bengali. We do not identify any individual by ethnicity in order to preserve anonymity; our participants were from diverse backgrounds (see Table 1). Four students were international; they did not live in Australia prior to medical schoolthree females and one male. 
Table 1: Participants' descriptions

\begin{tabular}{|lll|}
\hline Pseudonym & Gender & Age \\
\hline David & Male & 22 \\
\hline Kendi & Female & 19 \\
\hline Nicole & Female & 21 \\
\hline Kenneth & Male & 24 \\
\hline Tyrell & Male & 19 \\
\hline Keo & Female & 24 \\
\hline Sonita & Female & 21 \\
\hline Greg & Male & 20 \\
\hline Elizabeth & Female & 20 \\
\hline
\end{tabular}

\section{Data collection}

AA conducted a pre-study briefing where participants gave written consent, provided demographic details and trialled the smartphone app for the study. We used smartphones as they fit our theoretical and methodological grounding due to given the just-in-time capabilities to reduce recall bias b $^{25} 26$ and provide 'lived reality' data.

From the end of their second year, students were prompted to record an audio-diary entry into a smartphone app every two to three weeks for nine months; they started clerkships three months into the study. Students were provided with prompts that focused on our aim of how students narrate their navigation from pre-clinical to clinical training (Figure 1). Students were not given restrictions on a duration for their reflections but were advised to do it in a quiet, private area if possible. See Table 2 for sample prompts which guided audio-diary reflections, sample interview questions used during two interviews; see Appendix for more. Students were free to reflect outside of our prompts if desired. Two students eventually reflected by typed prose due to personal preference. Figure 1 summarises our data collection procedures over nine months. All methods were piloted on students outside the sampling frame. No significant changes were made as a result of piloting. 


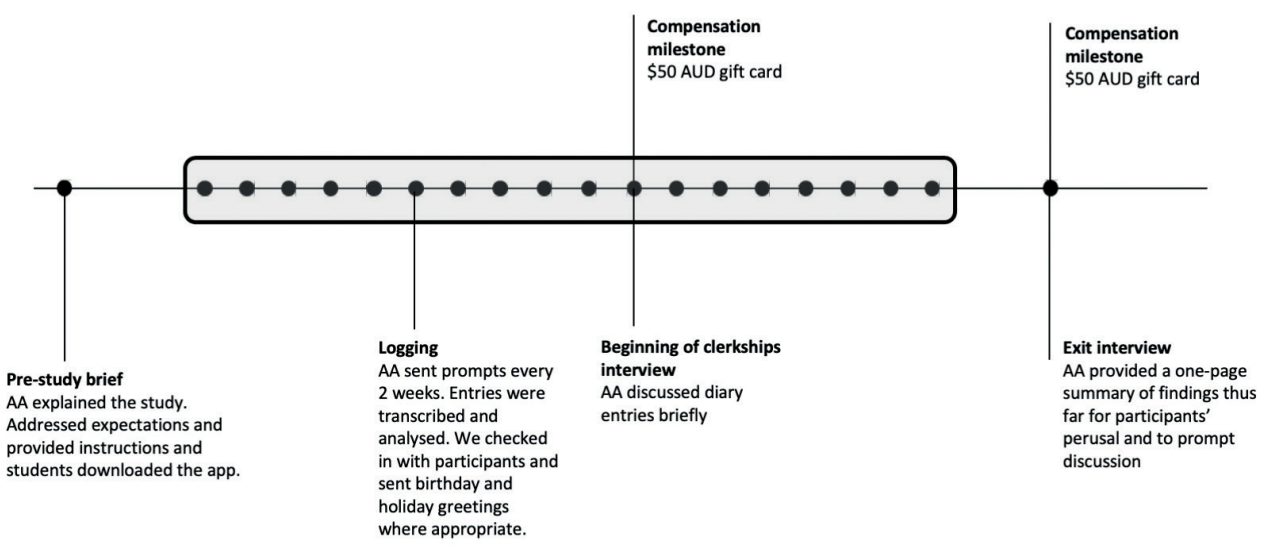

Figure 1: Data collection procedures for this paper

Note: The dots represent the frequency of prompts for students to log an audio-recording entry and all procedures occurred over nine-months. Students were prompted every two to three weeks.

Our research programme led us to investigate related but distinctively different research questions. In another study we explored the meaningful relationships influencing students' transition to clerkships ${ }^{27}$. In the current study, we focused on students' lived experience of navigating the transition from pre-clinical to clinical training and the process of identification. We collected data for the other study and the current study together during two interviews for logistical reasons and to minimise our encroachment on students' time.

AA invited students to participate in one interview at the beginning of clerkships and another at the end of the study period where the content of their audio diaries was further discussed and explored (See Table 2). For the exit interview, AA provided a onepage summary of students' audio-recordings as a starting point for discussion (See Table 2). These one-pagers represented our interim interpretations and this process served as member-checking ${ }^{28}$ as students assessed our provisional analyses of their audio-diary content. To end the exit interview, we discussed with students how and to what extent participating in our study impacted their transition experiences.

Nine participants generated a body of data comprising of 61 entries (7.4 per participant over nine months). Forty audio recordings ranged between two and 14 minutes and five typed diary entries ranged from 50 and 545 words. In total we interviewed eight participants for 64 minutes on two occasions (toward months four and nine of the study). 
Table 2: Sample prompts, sample questions from interview guides and timing within the study period

\begin{tabular}{|c|c|c|}
\hline & Month into study period & Samples \\
\hline Sample prompt & $\begin{array}{l}\text { Months 1-3 } \\
\text { (before clerkships) }\end{array}$ & $\begin{array}{l}\text { Are there any specific experiences that you } \\
\text { have had thus far that you think will help your } \\
\text { transition to the clinical year? }\end{array}$ \\
\hline Sample prompt & $\begin{array}{l}\text { Months 4-9 } \\
\text { (during clerkships) }\end{array}$ & $\begin{array}{l}\text { Describe any aspect of your clinical experience } \\
\text { over the past week that impacted your transition } \\
\text { to this placement in any way. }\end{array}$ \\
\hline $\begin{array}{l}\text { Sample interview } \\
\text { question }\end{array}$ & $\begin{array}{l}\text { Month } 4 \\
\text { (beginning of clerkships) }\end{array}$ & $\begin{array}{l}\text { [To Nicole] how did you deal with not having a } \\
\text { stable team? how do you 'begin anew' everyday? } \\
\text { can you give an example of what that means? }\end{array}$ \\
\hline $\begin{array}{l}\text { Sample exit interview } \\
\text { question }\end{array}$ & Month 9 & $\begin{array}{l}\text { What did reading that one-page summary of your } \\
\text { experiences thus far mean for you? What do you } \\
\text { think about it? }\end{array}$ \\
\hline
\end{tabular}

In order to immerse herself into the data, AA transcribed the first audio-diary recordings of all participants and the first two interviews. AA listed to all recordings and made notes. Then, a professional entity transcribed all other recordings verbatim. We offered transcripts to students all of whom agreed that the transcripts represented their recordings. AA de-identified all transcripts and gave each participant a pseudonym which did not reflect their background; we were careful not to use ethnically-suggestive names given the variation in ethnic background of the student body.

\section{Data analysis}

Data analysis was performed throughout data collection. AA openly coded transcripts followed by axial coding ${ }^{29}$ to put the fragments back together using the sensitising concept of modes of identification $n^{7}$. Wenger notes that newcomers may use these modes across boundaries or transitions as their unique identity is formed ${ }^{30}$. We therefore expected that our participants' use of these modes would be heightened as they found their footing in a new environment. We used constant comparison to refine codes and find consistencies and differences in participants' stories ${ }^{31}$; this allowed us to compare emerging findings on participants' lived realities to previous stories.

We then subsequently wanted to better understand participants' stories as a whole rather than simply as categories. To explore longitudinal threads in the data, we used time-ordered matrices ${ }^{32}$ and created research poems to re-story participants' narratives and enhance our analysis. Creating research poems allowed our participants' stories to be considered as a whole while making visible relationships between themes and sensitising concepts ${ }^{33,34}$ by focusing on the over-arching narrative plot of participants' stories. We were simultaneously interested in students' experiences and processes of transitioning to clerkships and identity development but also we wanted to know how these experiences and processes compared across the group of participants ${ }^{35}$. 
AA discussed brewing findings with DD and PWT followed by the whole research team after the first three months of collected data, and then iteratively. AA managed this data set in Atlas.ti version 8 (Berlin, Germany) which facilitated effective analysis and tracking codes across time.

\section{Creating research poems}

Poems can be used in qualitative research and medical education literature to both analyse and represent data ${ }^{32,36-38}$. We created research poems, using verbatim quotes as lines in the text, that reflected the essence of each participant's journey, over time, in their own words ${ }^{39}$; these poems were important in our analysis and interpretation of participants' narratives. As AA read transcripts and listened to audio files; she looked for and highlighted words, phrases and sentences in each participant's dataset and listened to the rhythm in their speech ${ }^{39}$. AA used a free verse format for all poems which does not use constant patterns or rhyme but instead followed the natural speech allowing her to stay true to participants' voices ${ }^{40}$. Saying poems outloud was a part of this process. Verse breaks in poems represent either a new recording/interview or a critical change in perspective. Research poems aided the understanding of the complex, longitudinal phenomenon of transitioning while retaining the emotive participant voice resounding in transcripts.

DD reviewed one participants' dataset and research poem to confirm that the poem maintained the essence of the participants' experience when transitioning to clinical training while showcasing the common threads of modes of identification ${ }^{7}$. In keeping with research poetry conventions, we did not add any words or phrases of our own ${ }^{41}$, Since we are focused on narratives of students' lived realities of our participants, our research poems followed chronologically; words and phrases have not been taken out of order. AA sent research poems to participants as an additional member-checking exercise and asked them the extent to which the poems represented their various trajectories. DD read one poem alongside the dataset of that participant and agreed the poem accurately represented themes and concepts in his data. Participants were excited and intrigued but some were embarrassed on reading their journey and how they felt during that time period; participants felt they were significantly changed at the time of reading the poem. We thus grounded poems in the data making our findings trustworthy.

\section{Ethical considerations}

We obtained approval from the University's Human Ethics Committee ID H9989. In all procedures from recruitment to manuscript, we maintained anonymity and data security. 


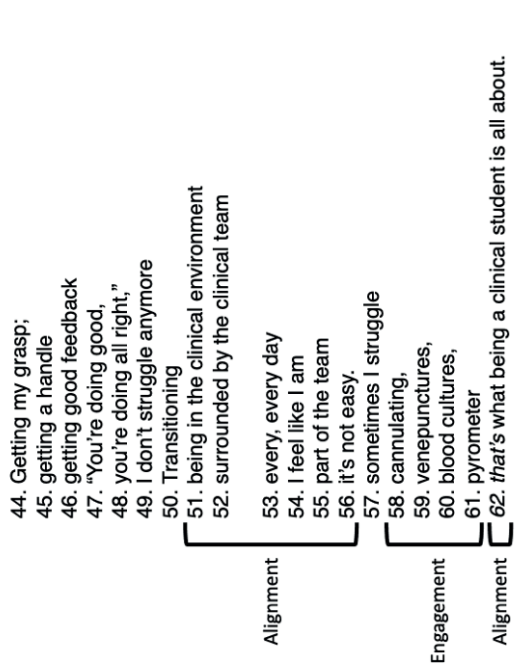

\section{L-9 чฉuоW}
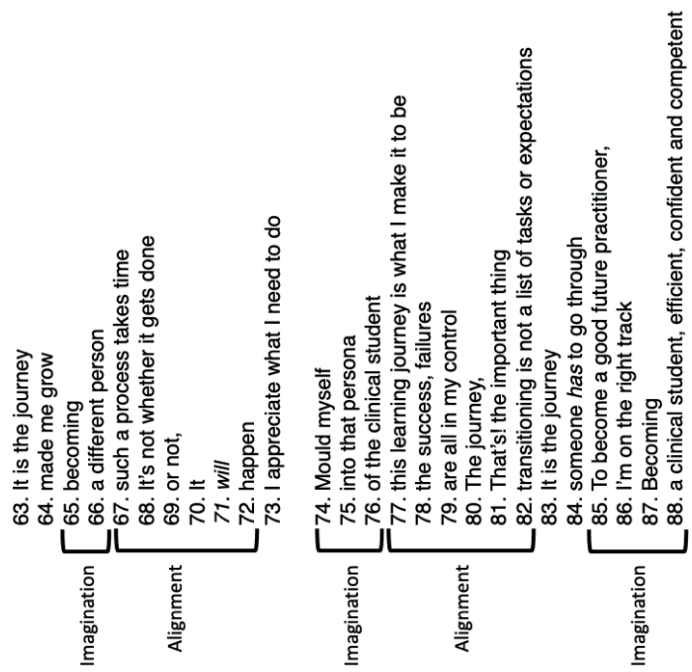

\section{6-8 чานоพ}

ㅁ
0
0
0
0
0
0
0
0
0
0

茞.

gु

8.

ฮั

㟧苔

ัँ

एव

के

远

劳覀

님

至 ठं

:

항

을 현

ฮ્ 이 1 d

렴

ำ

워

응.

哰

ช

范

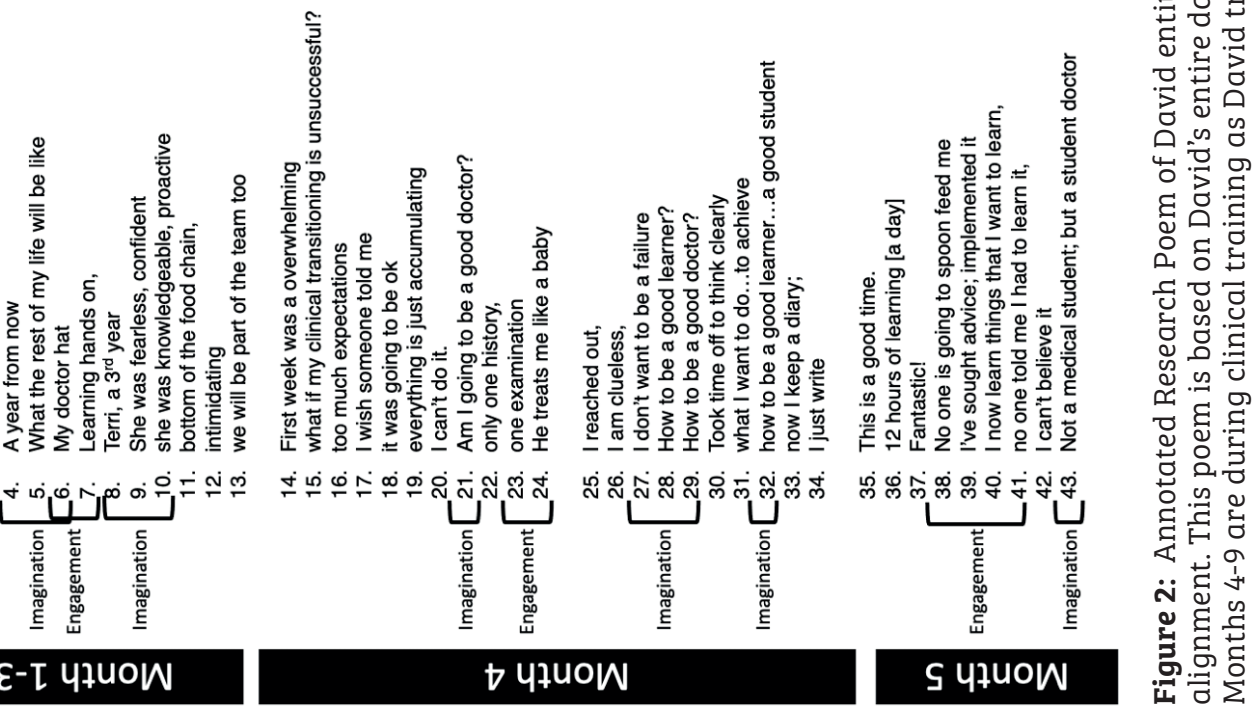




\section{Positioning and reflexivity}

AA was not involved in participants' teaching or assessment. AA kept reflective field and analysis journals and an audit trail of these and supervisor meetings was kept. AA is a PhD candidate trained as a medical doctor. Some of us are clinicians (PWT, IH, WH, $A A) ; D D$ is an educational scientist and we are all medical education researchers with qualitative research experience in Australia, The Netherlands and Barbados. Discussion with peers and supervisors helped interpretations and implications come to fruition.

\section{FINDINGS}

We first display a research poem for participant, David, based on his entire dataset (Figure 2) This poem encompasses our interpretations as students' transitioned to clinical training. The poem allows us to share David's entire journey, in an authentic, emotive way, using his voice and vulnerability. Through this poem we also indicate lines that showcase Wenger's three modes of identification at play (Figure 2). In this study, transitioning to clinical training was filled with positive and negative emotions and uncertainty around their current and future careers for most participants. David initially had mixed emotions ('excited' and 'nervous' - lines 1-2; Figure 2). Once in the clinical space this turned to anxiety due to many being overwhelmed with disappointment and uncertainty. David told us in his exit interview: 'I was just running around being all anxious and not knowing what to do...'. Eventually we see David shrieking 'fantastic!' (line 37 in Figure 2) once he had experienced a critical turning point five months into the study.

To understand these emotional 'ups and downs', we now delve further into participants' journey and outline three mechanisms that helped them to navigate these emotions and their experiences. We will illustrate these mechanisms using parts of the poem in Figure 2 but also with quotes from other participants' audiodiaries and interviews. For reference, any audiodiary quote occurring in month one was the beginning of the study when students were still in classroom-based training; interview and audiodiary quotes in months four to five occur at the beginning of clinical training and interview and audiodiary quotes from months eight to nine is at the end of the study period. 


\title{
Becoming engaged by learning to take charge
}

\author{
"no one is going to spoon-feed me \\ Ilearn things I want to learn" \\ -David's audio-diary, month five + research poem, lines 38 \& 40
}

On entry to clerkships, all students were confronted with the lived reality that the engagement they experienced at their respective workplaces was low. This led to frustration and confusion. During the first week of clinical training, students looked for, and depended on, invitations from doctors to become engaged. David's poem (line 22-24) showed how little he was able to participate initially:"...only one history, one examination, he treats me like a baby" [David, interview, month four]. This was also true for Greg: "I feel like for the most part I'm kind of just a fly on the wall." [Greg, audio-diary, month four]

Between months five and six of the study period, participants learned the primary mechanism to enhance engagement- learning to take charge of their clerkship experiences and initiated finding opportunities to meaningfully engage. David realized ...no one is going to spoon-feed me'. However, taking charge was more innate to some students than others and it took some participants less time than others to make this shift. Kendi reflected:

"...on the third or fourth day I realised I have to start talking to them a lot, actively asking questions to make me seem like I'm really keen for knowledge so that they will teach me."

Kendi, female, 19 years, audio-diary, month five

After making the decision to take ownership of their learning by forcing engagement, most participants began to showcase all the practices that they were now a part ofcannulations, venepunctures, blood cultures, pyrometers (line 58-61; Figure 2). Similarly, Kendi now recounted:

"... I did a few things like helping them to take bloods and ABG's and stuff which is pretty cool and sometimes I run down to pathology to grab something ... I feel like I'm actually helping the team in a way."

Kendi, female, 19 years, audio-diary, month six

Above we showed that students initially were disappointed that they were not actually engaged, they soon learned that by showing initiative and initiating interactions with the clinical team, they received invitations to became more engaged and felt more positive. 


\title{
Shaping their image of self through engaging in team tasks and reflecting on role-models
}

\author{
"...not a medical student but a student doctor" \\ -David's research poem, audio-diary, month five + research poem line 43
}

Prior to commencing clerkships, participants were already thinking of the future and how clinical training could support their upcoming career. David looked forward to 'what the rest of my life will be like' (line 4; Figure 2). However, once clerkships began, participants initially struggled to identify their roles; we see David questioning his future: '...am I going to be a good doctor?' (line 21; Figure 2). Similarly, Nicole described an experience where she felt unable to fulfil clinical tasks; this shook her image of her role on the team:

\begin{abstract}
"...I was asked by my team, ah, to take some cannulas. The first time I tried, I was unsuccessful, and so was the second time. I was feeling quite down and disappointed... cannulation is one of the big ways that you can make your contribution to the team and actually help out, and I was starting to think that I was never going to be able to do it..."
\end{abstract}

Nicole, female, 21 years, audio-diary, month five

As time passed, most students started to recreate a specific image of who they could be as a doctor in the future. Five months into clerkships we note David seeing himself differently: '... not as a medical student but a student doctor...becoming a different person. (figure 2 lines $43 \& 65$ )'By the end of the study some participants reflected on what skills they hoped to attain that were relevant to their future. Nicole recorded:

"... acquiring the qualities necessary to make a good doctor. I've realised that I (hopefully) don't have very long to go before I graduate and enter the workforce - I have to focus on both gaining the critical knowledge and skills necessary, but also crucial traits such as patience and empathy...".

Nicole, female, 21 years, audiodiary, month eight

The primary mechanism through which students recreated their image of current and future was through role modelling. David found a role model in a near-peer student, Terri, he admired and sought to emultate four qualities he saw '..fearless, confident... knowledgeable, proactive' (lines 9 and 10; Figure 2). Over time, students also identified behaviours they did not want to absorb from negative role models. Kenneth reflected:

"... a lot of the things that I see myself becoming, are influenced by behaviours that I don't want to have, so like when I see a doctor not own up to a mistake or behave rudely to another health professional or to the patient, I feel like a lot of my inspiration of how I want to behave comes from what I don't want to be mirrored in other people rather than being inspired..."

Kenneth, male, 24 years, audiodiary, month five 
Above we exhibited how students' image of self changed over their journeys and how their journey took them from excited visions of themselves as doctors, to managing doubts just when they entered clerkships. We showed how they recreated and 'moulded' their image of current and future self by engaging in team tasks and finding role models.

\title{
Adapting flexibly to clerkship norms by managing expectations and adopting a journey mindset
}

\author{
"...the journey, \\ that's! the most important thing" \\ David, audio-diary, month $8+$ research poem lines 86 \& 87
}

On starting clerkships, many students' expectations for starting clinical training did not align with their reality. Students encountered the lived reality of being at the 'bottom of the food chain' (line 11; Figure 2) and the medical hierarchy. Further, David, and others, expected to be engaged and became overwhelmed by a clerkship where he was minimally engaged leading him to be believe: '...I can't do it' (line 20; Figure 2). Encountering the reality of frequent changes in students' supervision interfered with their desire for guidance. This frequent supervisory rotation led some students feeling a constant need to 'start again' daily and not feeling integrated in the clinical space. Nicole reflected:

\begin{abstract}
"The doctors are generally nice and encouraging but I'm sent off with different registrars every shift and I feel like I have to "start again" every day. Every doctor has different expectations of a student...That's something I've had to quickly figure out with each doctor every shift and had to work around it... the best way to manage this is to be confident and put myself out there."
\end{abstract}

Nicole, female, 21 years, typed diary, month seven

Exposure to mal-alignment of expectations to reality led to students learning that the primary mechanism to align their behaviour and expectations with clerkship norms was first to have low expectations, this allowed them to be more open to their lived experiences. Most students then figured out they had to be flexible and adopt a journey mindset where they accepted the ups and downs as a part of their experiences. In David's research poem, we see a visible mindset shift; 'It will happen, I appreciate what I need to do'.. this learning journey is what I make it to be, the success, failures are in my control' (lines 77-79; Figure 2). Similarly, toward the end of the study Nicole reflected: 
"I feel that the key to transitioning is adapting your mindset ... a lot of it also comes down to being adaptable and flexible with what you've been given. Sometimes a doctor can be indifferent, there can be poor teaching, unreasonable expectations in terms of attendance, etc. The key skill to learn here is to not let that overwhelm you and to go out of your way to find opportunities for learning... So I believe I have transitioned successfully - through the support I have received, and also through adapting my approach to Medicine."

Nicole, female, 21 years, typed diary, month eight

Above we indicate how students flexibly aligned with clerkship norms by managing expectations, adopting a journey mindset.

\section{DISCUSSION}

Over nine months, we saw our participants develop positive and negative emotions, as they navigated the transition from pre-clinical to clinical training, and developed an identity based on their interactions, experiences and reflections. Students became more engaged over time by learning to take charge, they shaped their image of self through engaging in team activities and reflecting on role models; and flexibly adapted to clerkship norms by managing expectations and adopting a journey mindset.

How do our conclusions fit with earlier studies? Like in other studies, some of our novice undergraduate students sometimes found it difficult to manage emotions ${ }^{42,43}$. When participants perceived they were outsiders, this led to negative emotions and doubts. Secondly, we agree with other authors that role models are a powerful influence on students' identity formation ${ }^{17,18}$. In this study, through reflections, students were able to navigate tensions when they encountered negative role modelling. Like Adema et al, we found social interactions to be intricately linked with students' identity formation ${ }^{18}$. Further, Adema et al found the modes of imagination and alignment to be lacking in undergraduate medical students ${ }^{18}$. Our students learned how to negotiate malalignment between their expectations and lived reality. Such negotiation of alignment is a skill which is a part of learning ${ }^{44-46}$. Thus, this study was able to shed light on student identity formation over time by having students story their experiences as their identities were created through the lens of modes of identification?

We found the three modes of identification are intertwined and do not exist in isolation ${ }^{7}$. Increased engagement led to the identity of a being an active participant in the clinical space. Having an image of self was important in helping students flexibly adapt their behaviour and mindset to their identified goals and clerkship norms. Thus, as engagement fueled imagination, imagination was a stimulus for alignment. We show how these modes of identification change over time in a medical context. 


\section{Strengths and limitations}

Our use of Wenger's modes of identification ground our findings in theory. We collected longitudinal data about a transition in the medical training continuum which is previously lacking in our field ${ }^{1,2,42}$. Using research poems to analyse and present our findings is novel and allowed us to minimize the loss of the longitudinal nature of our data that can occur sometimes in longitudinal qualitative research if data is coded as one unit without allowance for how codes change with the passing of time ${ }^{47}$. Lastly, we reduced recall bias by having participants continuously reflect in the moment as their transition experiences and identity were developing.

However, this study took place at a single institution which could limit transferability although our findings could have relevance for other health professions experiencing similar transition challenges ${ }^{48,49}$. The researcher-participant relationship could be both a strength and a limitation as AA developed a close relationship with the participants. Though some participants might have felt compelled to continue participation due to this bond, in reality, many participants saw AA as a role model or 'big sister' leading participants comfortable to be vulnerable. Being presented with their poems and previous diary entries and reflecting on them could infact have impacted participants' developing mindset and identity. Thus we inadvertently could have conducted a type of participatory action research ${ }^{50}$.

\section{Suggestions for future research}

We found that being proactive and taking charge was a strong mechanism for engagement. Proactivity was more innate in some students than others. Further exploration of being proactive and how to predict proactivity could be useful. Some participants used their transcripts in their personal e-portfolios and exploring how reflections impact on transitions is an area for future research ${ }^{6}$. Lastly, we collected selfreport data only, an observational study could be beneficial to uncover true processes and outcomes of transitions and identification.

\section{Suggestions for future practice}

We found that by encouraging participants to reflect, they became active participants in their own identity formation ${ }^{17,51}$. Having students reflect using audio-diaries could be a powerful "boundary crossing activity" . Boundaries can be learning assets and there should be no expectation that they are to be smooth7. Instead of seeking smooth transitions, transitions should be lived, reflected on and supported. Participants appreciated the rocky journey; the ups and downs. Indeed, previous literature shows that the stress associated with transitioning can be motivating, if in a supportive environment ${ }^{1,52,53}$. Therefore, instead of 'cookie cutter' interventions (e.g. inductions) to smooth transitions by bridging the knowledge and skill gap between phases, 
future strategies should focus on support for example through longterm mentorship, scaffolding ${ }^{54}$ and coaching ${ }^{18}$ that supports students while transitioning to a new learning environment. In so doing, we can legitimise the student identity ${ }^{54}$ as they slowly develop their professional identities in a supported fashion.

We conclude with a short poem summarizing our main messages, created with words and phrases from this paper.

\author{
Lived reality \\ Their own words \\ Turning points \\ Their journey \\ Boundary crossing \\ Across the landscape \\ Part of the team \\ Their identity \\ Finding opportunities \\ Becoming \\ Shifting mindsets \\ Not medical students, \\ but student doctors
}

Becoming 


\section{APPENDIX}

Table 1: Audio-diary prompts

Months 1-3 Remember we are focusing on your experiences as you transition into the clinical environment. Comment on the issues below. You can talk in as little or as much detail as you would like. Some of these questions may be more relevant to others than you; you might spend more time on some prompts than others.

1. Besides this prompt, have you thought about the upcoming clinical year?

2. What comes to mind as you think about entering next year?

a. Do you have any specific expectations?

3. Are there any specific experiences that you think will be useful to help you transition to the clinical year? How so?

4. Are there any specific experiences that you have had thus far that you think will help your transition to the clinical year? How so?

5. Anything else you would like to talk about?

Months 4-9 Remember we are focusing on your experiences as you transition into the clinical environment. Comment on the issues below. You can talk in as little or as much detail as you would like. Some of these questions may be more relevant to others than you; you might spend more time on some prompts than others.

1. Describe any aspect of your clinical experience over the past week that impacted your transition to this placement.

2. How much support do you get from those around you? Explain

3. Were there any specific experiences in the past week that influenced your transition to this clerkship in any way? Can you tell me more?

4. How easily have you fitted into your role as a new clinical student? Explain

5. How are your experiences thus far affecting you? Explain

6. Is there anything else that would have helped? Explain

7. Anything else you would like to talk about?

Box 1: Interview schedule

1. How well did you think you are coping with the transition to clinical training?

2. How do you think you have changed from the beginning until now?

a. What led to those changes?

3. Looking back are there any specific factors that you think helped your transition to this phase?

4. What educational activities had the most impact on your transition and adjusting to the clinical year? Tell me more about the impact of these activities

5. Which people had an impact on your transition and adjusting to the clinical year? Which persons and in what way? Tell me more about the impact.

6. Apart from the audio-recordings in this study, can you remember any time as you transitioned to the clinical year when you reflected on your transition experiences?

a. What prompted that reflection?

b. Following that reflection what happened?

7. How is this study influencing your experiences transitioning?

a. Did it have any impact on your relationships?

b. Did it have any impact on your learning? How so?

8. Could you see yourself using audio diaries in the future for reflection? 


\section{REFERENCES}

1. Atherley A, Dolmans D, Hu W, Hegazi I, Alexander S, Teunissen PW. Beyond the struggles: A scoping review on the transition to undergraduate clinical training. Medical education. 2019;53(6):559-570.

2. Gordon L, Jindal-Snape D, Morrison J, et al. Multiple and multidimensional transitions from trainee to trained doctor: A qualitative longitudinal study in the uk. BMJ open. 2017;7(11):e018583.

3. O'Brien BC. What to do about the transition to residency? Exploring problems and solutions from three perspectives. Academic Medicine. 2018;93(5):681-684.

4. Teunissen PW, Westerman M. Opportunity or threat: The ambiguity of the consequences of transitions in medical education. Medical education. 2011;45(1):51-59.

5. Young M, Thomas A, Lubarsky S, et al. Drawing boundaries: The difficulty in defining clinical reasoning. Academic Medicine. 2018;93(7):990-995.

6. Yardley S, Westerman M, Bartlett M, Walton JM, Smith J, Peile E. The do's, don't and don't knows of supporting transition to more independent practice. Perspectives on medical education. 2018;7(1):8-22.

7. Wenger-Trayner E, Fenton-O'Creevy M, Hutchinson S, Kubiak C, Wenger-Trayner B. Learning in landscapes of practice: Boundaries, identity, and knowledgeability in practice-based learning: Routledge; 2014.

8. Van Hell EA, Kuks JB, Schönrock-Adema J, Van Lohuizen MT, Cohen-Schotanus J. Transition to clinical training: Influence of pre-clinical knowledge and skills, and consequences for clinical performance. Medical education. 2008;42(8):830-837.

9. Atherley A, Hambleton IR, Unwin N, George C, Lashley PM, Taylor CG. Exploring the transition of undergraduate medical students into a clinical clerkship using organizational socialization theory. Perspectives on medical education. 2016;5(2):78-87.

10. O'Brien BC, Poncelet AN. Transition to clerkship courses: Preparing students to enter the workplace. Academic Medicine. 2010;85(12):1862-1869.

11. Gale T, Parker S. Navigating change: A typology of student transition in higher education. Studies in Higher Education. 2014;39(5):734-753.

12. O'Brien BC, Battista A. Situated learning theory in health professions education research: A scoping review. Advances in Health Sciences Education. 2020;25(2):483-509.

13. Wenger E. Communities of practice: Learning, meaning, and identity: Cambridge university press; 1999.

14. Van der Zwet J, Zwietering P, Teunissen P, Van der Vleuten C, Scherpbier A. Workplace learning from a socio-cultural perspective: Creating developmental space during the general practice clerkship. Advances in Health Sciences Education. 2011;16(3):359-373.

15. Helmich E, Dornan T. Do you really want to be a doctor? The highs and lows of identity development. Medical education. 2012;46(2):132.

16. Balmer DF, Teunissen PW, Devlin MJ, Richards BF. Stability and change in the journeys of medical trainees: A 9-year, longitudinal qualitative study. Academic Medicine. 2020.

17. Cruess RL, Cruess SR, Boudreau JD, Snell L, Steinert Y. A schematic representation of the professional identity formation and socialization of medical students and residents: A guide for medical educators. Academic Medicine. 2015;90(6):718-725.

18. Adema M, Dolmans DHJM, Raat J, Scheele F, Jaarsma ADC, Helmich E. Social interactions of clerks: The role of engagement, imagination, and alignment as sources for professional identity formation. Academic Medicine. 2019;94(10):1567-1573.

19. Green J, Thorogood N. Qualitative methods for health research: sage; 2018.

20. Creswell JW, Creswell JW. Qualitative inquiry \& research design : Choosing among five approaches2013. 
21. Clandinin DJ, Connelly FM. Narrative inquiry: Experience and story in qualitative research. 2000.

22. Bleakley A. Stories as data, data as stories: Making sense of narrative inquiry in clinical education. Medical education. 2005;39(5):534-540.

23. Marshall C, Rossman GB. Designing qualitative research. 4th edition ed. Thousad Oaks:: Sage publications; 2014.

24. Sjollema SD, Hordyk S, Walsh CA, Hanley J, Ives N. Found poetry-finding home: A qualitative study of homeless immigrant women. Journal of Poetry Therapy. 2012;25(4):205-217.

25. Atherley A, Hu W, Teunissen PW, Hegazi I, Dolmans D. Appraising the use of smartphones and apps when conducting qualitative medical education research Medical Teacher In Press; In Press.

26. Lingard L, Kennedy TJ. Qualitative research methods in medical education. Understanding medical education: evidence, theory and practice. 2010:323-335.

27. Atherley A, Nimmon L, Teunissen PW, Dolmans D, Hegazi I, Hu W. Students' social networks are diverse, dynamic and deliberate when transitioning to clinical training. Med Educ. 2020;n/a(n/a).

28. Birt L, Scott S, Cavers D, Campbell C, Walter F. Member checking: A tool to enhance trustworthiness or merely a nod to validation? Qualitative health research. 2016;26(13):1802-1811.

29. Morse JM, Stern PN, Corbin J, Bowers B, Charmaz K, Clarke AE. Shifting the grounds: Constructivist grounded theory methods. Developing grounded theory: Routledge; 2016.

30. Wenger E. Communities of practice and social learning systems: The career of a concept. Social learning systems and communities of practice: Springer; 2010.

31. Chun Tie Y, Birks M, Francis K. Grounded theory research: A design framework for novice researchers. SAGE open medicine. 2019;7:2050312118822927.

32. Miles MB, Huberman AM. Qualitative data analysis: An expanded sourcebook: sage; 1994.

33. Drew S. Having cancer changed my life, and changed my life forever': Survival, illness legacy and service provision following cancer in childhood. Chronic Illness. 2007;3(4):278-295.

34. Glesne C. That rare feeling: Re-presenting research through poetic transcription. Qualitative inquiry. 1997;3(2):202-221.

35. Lal S, Suto M, Ungar M. Examining the potential of combining the methods of grounded theory and narrative inquiry: A comparative analysis. Qualitative Report. 2012;17:41.

36. Joseph K, Bader K, Wilson S, Walker M, Stephens M, Varpio L. Unmasking identity dissonance: Exploring medical students' professional identity formation through mask making. Perspectives on Medical Education. 2017;6(2):99-107.

37. Balmer DF, Devlin MJ, Richards BF. Understanding the relation between medical students' collective and individual trajectories: An application of habitus. Perspectives on medical education. 2017;6(1):36-43.

38. Byrne G. Narrative inquiry and the problem of representation:'Giving voice', making meaning. International Journal of Research \& Method in Education. 2017;40(1):36-52.

39. Lahman MK, Richard VM. Appropriated poetry: Archival poetry in research. Qualitative Inquiry. 2014;20(3):344-355.

40. Reilly $\mathrm{RC}$, Lee $\mathrm{V}$, Laux $\mathrm{K}$, Robitaille A. Using found poetry to illuminate the existential and posttraumatic growth of women with breast cancer engaging in art therapy. Qualitative Research in Psychology. 2018;15(2-3):196-217.

41. Butler-Kisber L. Artful portrayals in qualitative inquiry: The road to found poetry and beyond. Alberta Journal of Educational Research. 2002;48(3).

42. Helmich E, Bolhuis S, Dornan T, Laan R, Koopmans R. Entering medical practice for the very first time: Emotional talk, meaning and identity development. Medical Education. 2012;46(11):1074-1086.

43. Bolier M, Doulougeri K, de Vries J, Helmich E. 'You put up a certain attitude': A 6-year qualitative study of emotional socialisation. Medical education. 2018;52(10):1041-1051. 
44. Billett S. Workplace pedagogic practices: Co-participation and learning. British journal of educational studies. 2002;50(4):457-481.

45. Olmos-Vega FM, Dolmans DH, Guzmán-Quintero C, Echeverri-Rodriguez C, Teunnissen PW, Stalmeijer RE. Disentangling residents' engagement with communities of clinical practice in the workplace. Advances in Health Sciences Education. 2019;24(3):459-475.

46. Teunissen PW. Experience, trajectories, and reifications: An emerging framework of practice-based learning in healthcare workplaces. Advances in Health Sciences Education. 2015;20(4):843-856.

47. SmithBattle L, Lorenz R, Reangsing C, Palmer JL, Pitroff G. A methodological review of qualitative longitudinal research in nursing. Nursing inquiry. 2018;25(4):e12248.

48. Weidman NA. The lived experience of the transition of the clinical nurse expert to the novice nurse educator. Teaching and Learning in Nursing. 2013;8(3):102-109.

49. Wright A, Moss P, Dennis DM, et al. The influence of a full-time, immersive simulation-based clinical placement on physiotherapy student confidence during the transition to clinical practice. Advances in simulation. 2018;3(1):3.

50. Ritchie J, Lewis J, Nicholls CM, Ormston R. Qualitative research practice: A guide for social science students and researchers: sage; 2013.

51. Monrouxe LV. Identity, identification and medical education: Why should we care? Medical education. 2010;44(1):40-49.

52. Liu C-H, Tang W-R, Weng W-H, Lin Y-H, Chen C-Y. The process of coping with stress by taiwanese medical interns: A qualitative study. BMC medical education. 2016;16(1):10.

53. Simmons B. Eustress at work: Extending the holistic stress model. In, dl nelson \& cl cooper (eds.), positive organizational behavior: London: Sage Publications; 2007.

54. Yardley S, Kinston R, Lefroy J, Gay S, McKinley RK. 'What do we do, doctor?'transitions of identity and responsibility: A narrative analysis. Advances in Health Sciences Education. 2020:1-19. 
Journey to becoming: Exploring students' lived reality and identity formation across the transition to clinical training 


$$
4
$$




\section{Students' social networks}

are diverse, dynamic and deliberate wen transitionirg clinical toing

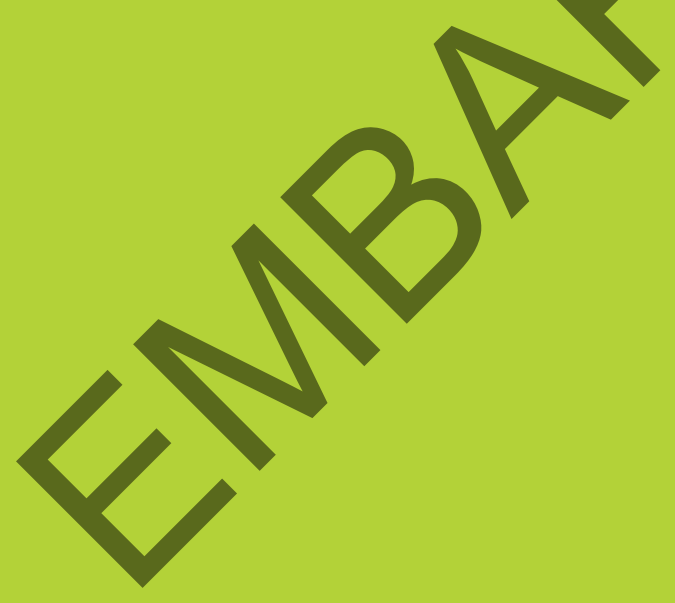

\section{Published as:}

Atherley AE, Nimmon L, Teunissen PW, Dolmans D, Hegazi I, Hu W.

Students' social networks are diverse, dynamic and deliberate when transitioning to clinical training.

Medical Education. 


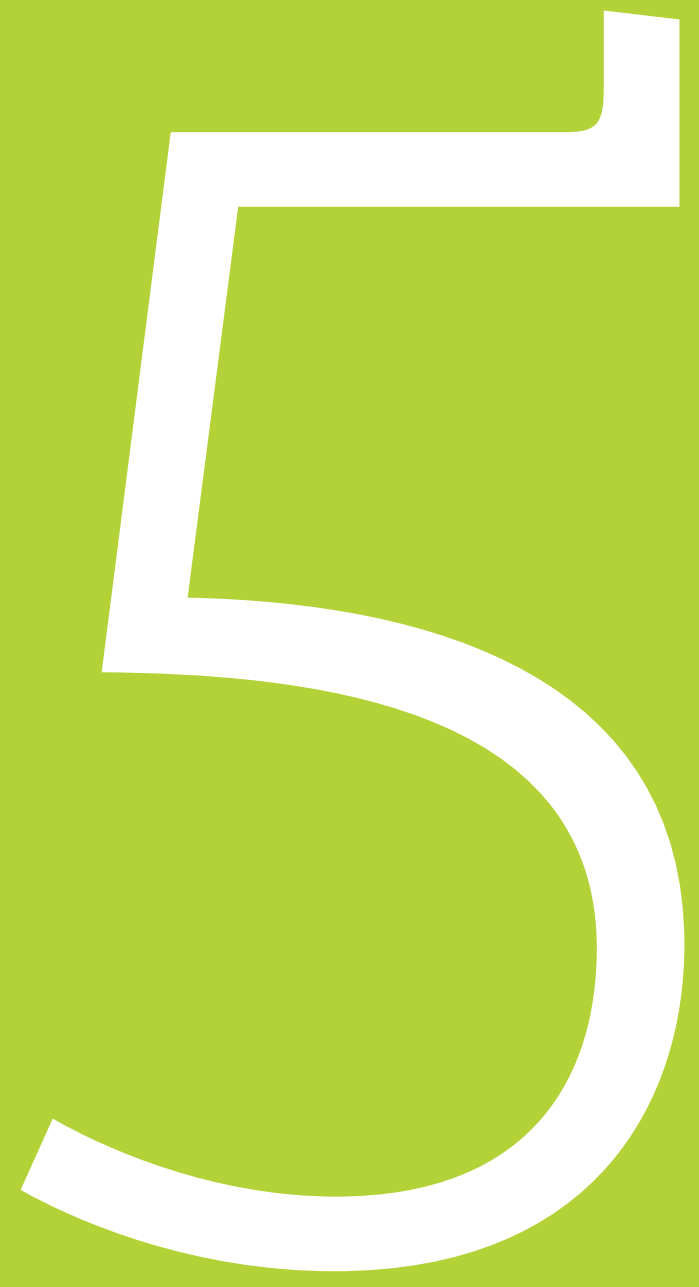




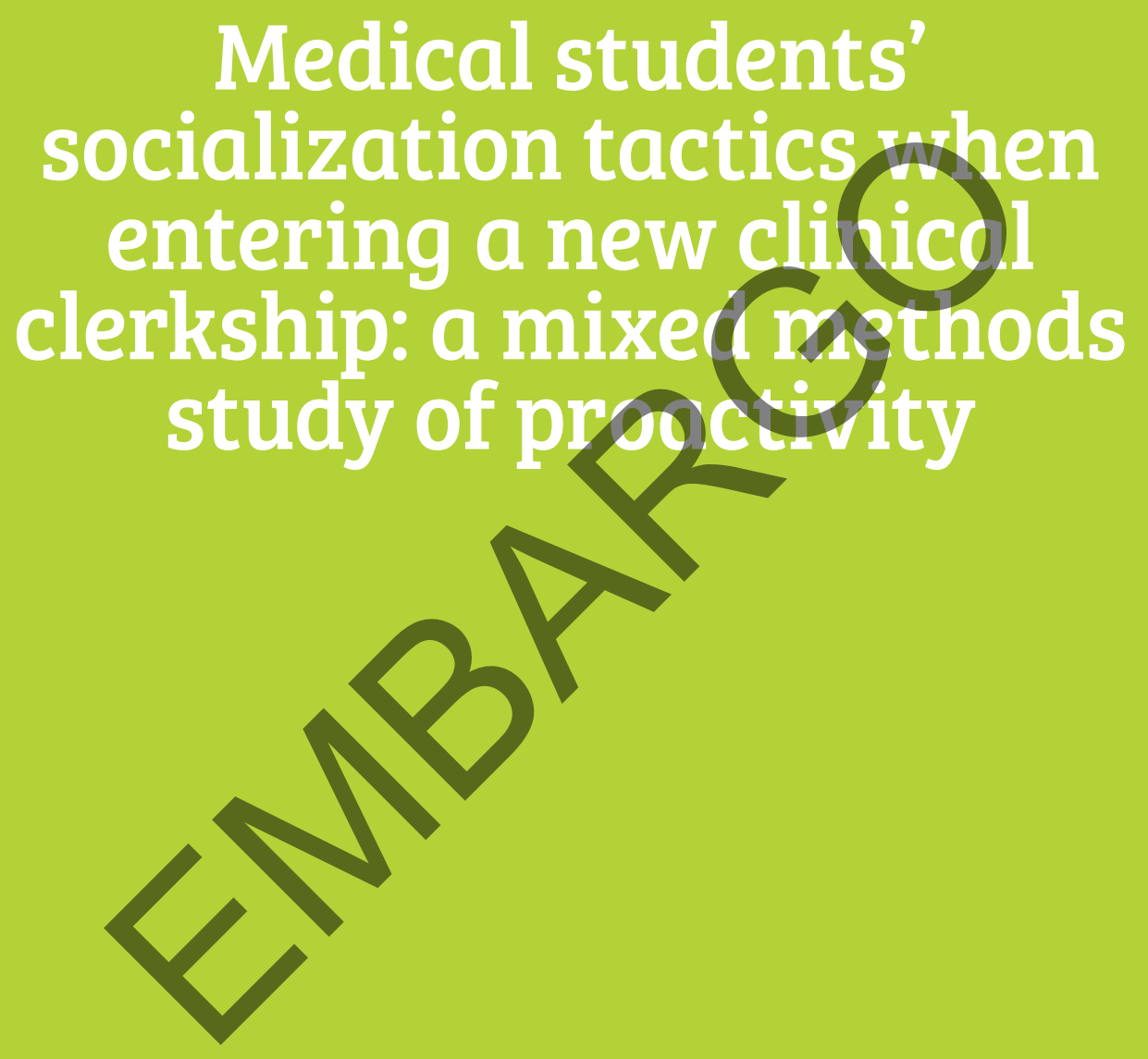




$$
6
$$




\section{Appraising the use of smartphones and apps when conducting qualitative medical education research}

\section{Published as}

Atherley A, Hu W, Teunissen PW, Hegazi I, Dolmans D.

Appraising the use of smartphones and apps when conducting qualitative medical education research: AMEE Guide No. 130.

Medical Teacher

2021 Jan;43(1):68-74 


\section{ABSTRACT}

Smartphone use is rampant in everyday life and is increasing in: patient management, teaching and learning of medicine and health research. There is untapped potential to use smartphones as research tools in MER for a range of research approaches. Qualitative research is increasingly common in medical education research (MER). Smartphone use as a research tool has not been well explored in MER and this Guide will be useful to researchers considering integrating smartphones specifically in qualitative MER. First, we discuss the potential for smartphones in qualitative MER. Then, we discuss the opportunities and drawbacks for using smartphones in qualitative MER. We then provide three principles to consider when conducting smartphone MER: communication, ethics and reflection. Next we share ten lessons that emerged from the literature and our experiences. We end by looking to the future of smartphones in qualitative MER and hope this Guide provides evidence-based information to optimise smartphone use in qualitative MER. This Guide is important as there is an urgent need to redefine ethical boundaries to account for blurred lines between personal and professional use of smartphones. 


\section{INTRODUCTION}

Smartphones have been used in patient management, teaching and learning of medicine and health research; less consideration has been given to smartphones in medical education research (MER). Smartphones are influential in many ways - our relationships with others, daily habits such as health care (Dorsey et al. 2017) and in education (Masters et al. 2016; Valle et al. 2017; Maudsley et al. 2019). As smartphones increase connectivity, there will be the urgent need to redefine ethical boundaries to account for the blurred lines between personal and professional use. Increases in smartphone use offer new opportunities in all aforementioned areas, including MER, but simultaneously bring challenges. This Guide will provide critical reflections on the opportunities and drawbacks for using smartphones in the medical education research arena. In this Guide we focus on smartphones, however the findings and suggestions that follow may apply to other mobile devices with overlapping capabilities (e.g. tablets, smart watches). Additionally, even though we discuss medical education research, the evidence and suggestions are likely relevant to other health professions education research.

Smartphones and their software applications (commonly called "apps") have successfully penetrated the medical education environment; the vast majority of medical students and doctors own a smartphone (Ramesh et al. 2008; Koehler et al. 2012; Browne et al. 2015; Patel et al. 2015; Raiman et al. 2017). Smartphones are used every day in patient care to assist decision-making (Mosa et al. 2012; Patel et al. 2015; Valle et al. 2017), in medical education by facilitating how medical students and residents learn (Mosa et al. 2012; Browne et al. 2015; Maudsley et al. 2019), and in healthcare research by facilitating global participation in studies of asthma, breast cancer and Parkinson's disease (Dorsey et al. 2017). Simultaneously, smartphones have advanced general research processes (Garcla et al. 2016). Smartphones in quantitative studies can reduce data collection costs, improve data management and maintain participant interest (Garcla et al. 2016). Recently, authors have also recognised the use of smartphones in qualitative research - in ethnography (Beddall-Hill et al. 2011), interview research (Beddall-Hill et al. 2011; Redlich-Amirav and Higginbottom 2014) and longitudinal data collection (Garcia et al. 2016). In medical education research (MER), smartphone use is often implicit rather than explicit, even though there are important considerations for using them in our field.

The first author is a PhD student and this Guide was inspired by her experience in developing research protocols for her first empirical study, a longitudinal narrative inquiry using smartphones as a research tool. She and her co-authors realised that the topic had not been well explored in the medical education research space. Thus far, smartphones and apps have been used as interventions to supplement learning 
in medical education, but there is untapped potential to use smartphones as research tools in MER for a range of research approaches.

Smartphone use in research should be critically considered and we hope this Guide will provide direction to researchers choosing to use smartphones in qualitative MER. Smartphones can indeed be used in quantitative research (Dorsey et al. 2017). Smartphones facilitate in-the-moment data collection and capturing experiences as they happen, but overt exploration of their use in qualitative MER is rarely apparent. We therefore chose to focus on qualitative MER due to our ongoing experiences and the explosive potential of using smartphones in qualitative inquiries.

In this Guide, we aim to:

- Provide readers with a critical appraisal of using smartphones as a research tool within qualitative MER through highlighting the opportunities and drawbacks that using smartphones may provide in qualitative MER.

- Consider the way forward in using smartphones in qualitative MER and share ten lessons grounded in the literature and our experiences.

\section{Qualitative research, smartphones and medical education research (MER)}

Qualitative research is a humanistic, person-centred way of uncovering reality (Holloway and Biley 2011). It is important to consider how any research tool fits into the assumptions inherent in a study's methods and theoretical background; this should be no different when using smartphones (Hein et al. 2011). Lingard reminds us that the importance of the tools in qualitative research lies in their critical purpose rather than the tools themselves (Lingard 2007). The just-intime capabilities of smartphones in qualitative research may reduce recall bias as participants have access to their smartphones most times in the day. This constant access facilitates instant reaction to an experience that which may otherwise fail to make it in a written diary entry (Garcia et al. 2016)

Smartphones can help ethnographers collect multiple forms of data in order to recreate events (Hein et al. 2011) facilitating interpretation and analysis. When using ethnography - an approach that uses observations, interviews and documents to explore social phenomena from multiple perspectives (Reeves et al. 2013) - we depend on the thick description of methods and events, reflexivity and triangulation of data obtained in different ways (Reeves et al. 2013). Hein notes that smartphones contribute to the epistemological assumptions in ethnography by supporting social constructionism (Burr 1998) through insight to multiple social realities(Hein et al. 2011). Ethnography as a methodology is increasing in MER (Atkinson and Pugsley 2005) having been used to explore bedside teaching (Atkinson 2018) and the implicit versus explicit curriculum in general paediatrics (Balmer et al. 2009). Smartphones complement this method of 
inquiry as medical education researchers continue to explore the practices and beliefs of medical trainees and professionals.

Smartphones, likewise, can help facilitate narrative inquiry research - an approach to inquiring into participants' experiences through their stories which considers the larger world in which the experiences are lived (Clandinin et al. 2017). Narrative inquiry is also increasing in MER (Clandinin et al. 2017) having been used to explore professional identities (Monrouxe 2009). Clandinin and colleagues note the need to create and use methods that are congruent with narrative inquiry principles. Smartphones are likely one piece of the puzzle allowing participants to story their experiences (storytelling) in real-time through audio recordings (Andrews et al. 2013; Garcia et al. 2016). Smartphones also create a remote space where participants may feel safe to tell their stories; this safety is critical to narrative inquiry (Clandinin et al. 2017).

\section{Opportunity I Smartphones can collect different types of data}

Smartphones can unlock multiple data sources to researchers, which can help them answer research questions within qualitative research (Hein et al. 2011). Smartphones are capable of replacing the functions of a digital camera, video camera, voice recorder, note pad, drawing pad, and geo-tracking; they are like 'electronic Swiss Army knives' (Barkhuus and Polichar 2011). Outside of MER, in an ethnographic exploration of young males' consumer experiences, smartphones were used to record field notes and interviews and also to take photographs (Hein et al. 2011). Within MER, smartphones can facilitate data collection within the nine observational dimensions for an ethnographic study described by Reeves and colleagues. Balmer and colleagues used observations and interviews during their ethnography (Balmer et al. 2009). Smartphones can facilitate such observations through digital drawings of the location of participants and objects and how they interact in space, to record informal interviews about participants' feelings and general field notes. Diaries are a common data collection tool within narrative inquiry studies; diaries can be written or audio-recorded. Monrouxe used dictaphones for participant audiodiaries during narrative inquiry (Monrouxe 2009) while Gordon and colleagues (2017) used smartphones for audiodaries.

\section{Opportunity I Smartphones can make data collection more efficient}

Using smartphones in research could save time through the real-time digitisation, management and backup of data (Redlich-Amirav and Higginbottom 2014; Garcia et al. 2016). Garcia et al. described being able to remotely monitor data collected via an app, which facilitated automatic notifications as reminders for participants (Garcia et al. 2016). Smartphones are portable, multifunctional devices and allow efficient data collection by minimising the need for participants to juggle multiple devices in order to participate (Beddall-Hill et al. 2011). In narrative inquiries, it has been recognised 
that audio diaries benefit some participants, as less time is taken to complete them, and reduce cognitive processing versus a written diary (Fisher and Noble 2004). Lastly, smartphones can maintain participants' interest due to the everyday integration of the smartphone in everyday life (Garcia et al. 2016). This however does not guarantee fewer dropouts during longitudinal research (Garcia et al. 2016). Oppenheim quite accurately describes many researchers' early experiences in setting up at the beginning of an interview, trying to hide frantic attempts to welcome the participant, gain consent while setting up the recording equipment and making sure it is optimally placed (Oppenheim 2000). Smartphones are used by most persons daily and this familiarity could facilitate a smoother entry into research interviews. Additionally, the smartphone can be used to digitally take notes; these can then be analysed alongside the interview transcript (Beddall-Hill et al. 2011). While we did not find examples of improved efficiency using smartphones within MER, Gordon and colleagues found lower attrition rates when using smartphones for a longitudinal audio diary study exploring the trainee to trained doctor transition (Gordon et al. 2017).

\section{Drawback | Smartphones can negatively impact data quantity and quality}

Using smartphones could, however, negatively impact the quantity and quality of data collected. Reduced data quantity from dead smartphone batteries could lead to participants not being able to complete their research tasks on time. Smartphone apps installed for the purpose of research could introduce software viruses and contribute to dead batteries by using excess battery power. Additionally, having participants answer questions remotely using their smartphones is risky as the notifications may fall victim to the barrage of information continually popping up on their phones that is often ignored. Some authors found that response times when answering questions using a smartphones are longer compared with using a computer due to many reasons including increased distractions (Lynn and Kaminska 2013). Regarding data quality, some academics were mystified at the use of a smartphone to record an interview as it may not be seen as a 'serious' research tool due to its primarily social usage, raising queries about data security (Beddall-Hill et al. 2011). This could potentially influence the quality of data obtained as participants may not take the process seriously. All the aforementioned ways in which smartphones can affect data quantity and quality are relevant in medical education research (MER). Smartphones are used every day in healthcare and medical education and research prompts may be lost among competing reasons for smartphone use.

\section{Drawback | Smartphones threaten privacy}

Qualitative MER is often done in clinical healthcare settings when exploring trajectories of medical students, residents and even the influence of patients on medical education. The importance of protecting privacy is increasing. 
General Data Protection Regulation (Official Journal of the European Union 2016) laws are being enforced in the European Union and worldwide. This has resulted in changes to many institutional policies. Within many health care institutions, strict policies on the use of smartphones in the clinical context are being implemented (John 2018). These policies stipulate security requirements for smartphones (The University of Alabama at Birmingham 2016), and the requirement of consent for taking photographs or identifiable information of anyone (Health Facilities Scotland 2008). These policies are equally, if not more, relevant to medical education researchers as we conduct research in these multifunctional environments.

Some participants may lose awareness that they are being observed and recorded (Beddall-Hill et al. 2011; Hein et al. 2011). Due to smartphones' ubiquitous nature, using them in qualitative research could lead to the researcher becoming invisible in the environment leading to 'covert surveillance' (Beddall-Hill et al. 2011) - smartphones may not always be recognised to be a research tool. Even though this might be considered an advantage by reducing observer effect, it could mean that data are collected that participants would otherwise prefer to be private (Beddall-Hill et al. 2011). Additionally, apps could present a security risk to participants as not all apps may have standardised data security procedures and therefore may not reach standards required for healthcare mobile device policies for security.

Within MER, when collecting data in the clinical environment, participants may provide consent that allows us to observe and interview them informally. However, bystanders in the complex clinical environment may be unintentionally recorded; their individual consent may be logistically difficult to gain. As smartphones are so integral to everyday life, bystanders may not recognise that recording is occurring, which augments the risks. How can the voices in the background of researchers' field audio-notes and persons in the background of photographs be protected? Anonymising photographs is more complicated than simply cropping and blurring images as digital photographs on smartphones often carry information such as date and exact location, which may make it possible to triangulate information, thus eroding anonymity (John 2018).

\section{Drawback | Smartphones introduce distractions}

Smartphones introduce another source of interruption, multitasking and distraction into the hospital environment (Katz-Sidlow et al. 2012). Smartphones enhanced observations in an ethnographic study within marketing (Hein et al. 2011), however, this benefit could be overshadowed when brought to the healthcare context due to the risks involved. Distraction of clinicians by smartphones occurs when one's primary task is interrupted by any use of their smartphone (McBride 2015). The term 'distracted doctoring' has been coined by Papadakos highlighting the dangers of seductive mobile 
devices (Papadakos and Bertman 2017). These interruptions can have significant consequences on both patient care (Halamka 2011; Wu et al. 2013), and learning (Fox et al. 2009) as there is the potential for missing important information (Katz-Sidlow et al. 2012). When using smartphones for MER, prompts may be used to stimulate participant responses. A review found that distraction by social connectivity could affect the impact mobile devices have when used in the clinical setting for learning (Maudsley et al. 2019). Using smartphones to conduct MER intensifies distraction in the clinical setting.

\section{Principles of smartphone use in qualitative medical education research (MER)}

Based on the aforementioned opportunities and drawbacks to using smartphones, we offer three principles that a medical education researcher using smartphones as a research tool should consider during protocol development, ethics application, data collection and storage.

\section{Communication}

Communication between researchers and participants should take place through previously agreed upon channels, which should include secure apps or institution emails. This facilitates fast resolutions of technical issues and an outlet for participants to voice concerns. Communication is key to reassure participants of their protection. One such opportunity for this is during consent where researchers can discuss the flow of data. In a case of academics who were fearful of using a smartphone to record interviews due to concerns about threatened data security (Beddall-Hill et al. 2011), reassurance and information could dispel these perceptions. It should be made clear when the device is recording and that it is not transmitting data during interviews. Sharing data with participants could function as member checking but also shows participants what data has been collected and facilitates dealing with any research use of data that participants are not comfortable with (Beddall-Hill et al. 2011). While in principle, participants should be free to withdraw part or all of their data at any time during the research process, it should be communicated that this can only be done if possible. For example, if their data has already been integrated through preliminary analysis, you can assure them of deletion of their raw data but it will not be possible to remove their existing input from aggregated growing analyses, although their privacy would be maintained. In the era of co-creation, including participants during protocol development could be potentially helpful to ensure procedures are acceptable for participants using their smartphones. Lastly, at an institutional level, similar to the proposed training for medical students and junior doctors on smartphone use (Maudsley et al. 2019), similar training for MER researchers would be beneficial. 
Table 1: Sample data management plan summary

\begin{tabular}{|c|c|c|c|c|c|}
\hline & Description & Origin & Format & Size & Data utility \\
\hline Audio files & $\begin{array}{l}\text { Audio files from } \\
\text { interviews and } \\
\text { audiodiaries }\end{array}$ & $\begin{array}{l}\text { Audiodiaries } \\
\text { and interviews }\end{array}$ & .mp3 & $216 \mathrm{MB}$ & Will be deleted after analysis \\
\hline Video files & $\begin{array}{l}\text { Video files from } \\
\text { participatory } \\
\text { interviews }\end{array}$ & $\begin{array}{l}\text { Participatory } \\
\text { interviews }\end{array}$ &. $\mathrm{mp} 4$ & $40 G b$ & Will be deleted after analysis \\
\hline $\begin{array}{l}\text { Interview \& } \\
\text { Audio diary } \\
\text { transcripts }\end{array}$ & $\begin{array}{l}\text { Interview } \\
\text { transcripts from } \\
\text { interviews and } \\
\text { audiodiaries }\end{array}$ & $\begin{array}{l}\text { Audiodiaries } \\
\text { and interviews }\end{array}$ & docx & $6 \mathrm{~Gb}$ & $\begin{array}{l}\text { Will be kept on an encrypted } \\
\text { hard drive and at the end of the } \\
\text { study uploaded to approved } \\
\text { institutional database or research } \\
\text { direct for duration as determined } \\
\text { by ethical board }\end{array}$ \\
\hline $\begin{array}{l}\text { Participant- } \\
\text { produced } \\
\text { diagrams }\end{array}$ & $\begin{array}{l}\text { Participant- } \\
\text { produced } \\
\text { diagrams from } \\
\text { participatory } \\
\text { interviews }\end{array}$ & $\begin{array}{l}\text { Participatory } \\
\text { interviews }\end{array}$ & .jpeg & $480 \mathrm{MB}$ & $\begin{array}{l}\text { Will be stored on approved } \\
\text { institutional database once } \\
\text { anonymised for duration as } \\
\text { determined by ethical board }\end{array}$ \\
\hline
\end{tabular}

\section{Ethics}

Institutional review boards (IRBs) have a role to play in policing protocols using smartphones to collect MER data. As smartphone use in research increases, it will be imperative that IRBs actively consider the implications for using smartphones to do MER. The consent process should be informed by a deep understanding of the implications of smartphone use and participants should be fully informed of the unique risks. Health care organisations and researchers should also consider whether participants should have institution-provided smartphones or if it is sufficient to use individual personal devices within institution policy. Research using mobile technology in education could consider moving from 'permission-seeking' modes of ethical approval toward iterative, incremental models of ethical approval when using technology like smartphones (Lally et al. 2012). Such a model would provide the flexibility necessary when conducting qualitative MER. Iterative ethical approval would allow researchers to efficiently gain further access as necessary as their research unfolds.

Since the launch of data protection protocols such as the European Data Protection Regulation, complete data management plans (European Research Council 2017) (see Table 1 and Box 1 for examples) should be critically considered, documented and submitted alongside ethical applications. This is especially important when designing a study using smartphones as a research tool. Storing data on internal smartphone storage or using native apps threatens participant privacy. As such, all data should be uploaded promptly and stored on secure app servers and those regulated by institutions. Regarding protecting 'unintentional participants', researchers and participants should avoid the voices, faces or identifiable attributes in video, audio and photos of persons and places that have not provided permission to be included in a study. Where their 
inclusion is inevitable, as much as is possible, their informed consent should be obtained at that point.

Box 1: Sample data management data flow system

1. Sanne will record audio diaries securely from September 2018 until March 2019 via her smartphone.

2. Sanne will take part in two participatory interviews with AA which will be audio recorded and will produce a concentric circles network map. The work area will be videotaped as well.

3. Sanne's audio recordings will be obtained by AA who upon downloading will assign Sanne a code- 001.

4. Sanne's audio recordings and interviews will be saved using her code e.g. 001-diaries.mp3; 001-interview1.mp3; 001-interview2.mp3; 001-interviewvideo. mp4; 001-ccmap.jpg.

5. Sanne's audio recordings and interviews will be sent to a professional transcription service (as 001-diaries or 001-interview1). The transcription service will sign a confidentiality form. The transcript names will follow the naming system for the recordings (e.g. 001-diaries.docx)

6. AA will de-identify the transcript and delete the identifiable version. This will be saved as 001-diaries_anon.docx.

7. AA will analyse Sanne 's data alongside all participants.

8. AA will delete the audio recordings, video recordings (of the workspace) and interview recordings following analysis of all participants.

Burning questions regarding the ethics of using smartphones in qualitative MER remain. (1) When should raw data be deleted when collected with smartphones? Whatever the decision, this should be disclosed in the ethics protocol and communicated to participants. (2) Is there a risk introducing a third party (e.g. apps) whereby we depend on them to delete the data from their servers? Just as many transcription companies sign confidentiality agreements with institutions, app developers should be required to do the same. (3) Do IRB blanket statements such as 'locking data in a locked cabinet or password protected computer' need to be reconsidered in the era of using smartphones as research tools? (4) Are there any legal concerns with data that were taken for research purposes but may be necessary for legal proceedings as evidence (e.g. tracking and location data)? Lastly, amidst global participation in health research through smartphone use (Dorsey et al. 2017), (5) is a global IRB system possible, as this could ultimately extend to MER using smartphones?

\section{Reflection}

Reflection is important in medical education practice (Mann et al. 2009) and research (Ng et al. 2015) and has the ability to change practice and understanding (Mann et al. 2009). Qualitative research often includes maintaining audit trails and research diaries. Through reflection, medical education researchers should also be flexible in their 
decisions for data collection to minimse risks and challenges. It may be beneficial to discuss with peers and potential participants from your sampling frame to help inform your research design choices. Published reflective papers report on the process choices researchers make when using smartphones in research, with explicit examples critical decisions made by researchers and questions still to consider (Beddall-Hill et al. 2011; Garcia et al. 2016). These papers are examples of how reflection could impact future research practices and protocols when using smartphones (Beddall-Hill et al. 2011; Garcia et al. 2016). Lastly, asking participants to discuss their experiences with the research process (Crozier and Cassell 2016) could be another way to improve future MER using smartphone research. Ultimately, when conducting MER, such flexible, intentional data collection could increase participant adherence while protecting both participants and patients. In addition to these principles, Box 2 describes ten lessons when using smartphones in qualitative MER grounded in the literature and our experiences.

Box 2: Ten lessons for using smartphones in qualitative medical education research

1. Beyond innovation, smartphones fit the principles of qualitative MER.

2. Smartphones can collect different types of data (audio, video, notes, photos, location)

3. Smartphones can make data collection more efficient

4. Smartphones can negatively impact data quantity and quality

5. Smartphones threaten privacy

6. Smartphones can perpetuate distractions in the clinical environment

7. Constant communication of risks and benefits to participants via an open agreed upon communication channel is important.

8. Institutional review boards have a responsibility to consider risks when using smartphones as they provide approval

9. A data management plan is critical

10. Reflection, peer discussion and participant feedback will launch the way forward in using smartphones in MER.

\section{The future of smartphones in MER}

In these days of internationalisation of medical education, MER could follow suit. Barring challenges and ethical considerations, could technology provide automatic translation that minimises the need for participants and researchers to speak the same language? Can medical students in the United States, the Caribbean, the UK, Europe, Australia, and Asia potentially take part in the same study, regardless of language, providing they meet the inclusion criteria? Just as apps have erased the geographical boundaries placed on health research and allowed global participation, especially for diseases with lower prevalence, could smartphones and apps be the start of true multi-institutional globalised MER? 
While researchers can use existing smartphone apps for their research, often the cost attached to existing apps is quite high and could reduce use in those with limited research budgets. Many apps that can facilitate research data collection are created for market research; commercial companies have high budgets. There is therefore an opportunity for the creation of low-cost research apps tailored for efficient and secure collection of audio, images, video, survey data while allowing for geo-tracking data in educational contexts.

It is rare to find meta-research on the impact of using smartphones or technology in research in medical education. McLeod and colleagues adopted socio-materiality - how the human and non-human relate to organise, allow and constrain social interactions - to explain that materials (e.g. mannequins, stethoscopes and technology) are not a neutral elements to human interaction in learning but impact agency and meaning making (MacLeod et al.; MacLeod et al. 2015). Future research could further explore socio-materiality theories to examine how smartphones and other mobile devices influence process and outcomes in MER.

\section{CONCLUSION}

The aim of this Guide was to provide guidance to design, conduct and reflect on the use of smartphones in medical education research. It is critical for researchers to share experiences in the academic literature to facilitate global progression of research processes. Smartphones can enhance the research purpose and fits the principles of qualitative MER. Researchers must however be mindful of using smartphones in MER as they can affect the research data, threaten privacy and perpetuate distractions. We suggest constant communication with participants, being reflective as a researcher and challenge institutional review boards to recognise their responsibility in monitoring the use of smartphones in MER. We look forward to seeing intentional, reflective use of smartphones in medical education research in the future.

\section{Practice points}

1. Identify a secure, fast communication channel with participants to facilitate remote discussion of issues and concerns during data collection.

2. Communicate risks to participants particularly if they are in the clinical setting regarding privacy risks to patients and others in the clinical environment.

3. Complete a data management plan to submit alongside ethics applications.

4. Consistently reflect and discuss the research process and concerns with peers 


\section{REFERENCES}

1. Andrews $M$, Squire $C$, Tamboukou M, editors. Doing narrative research. London: SAGE PUblications Ltd; 2013.

2. Atkinson P. 2018. The clinical experience, (1997): the construction and reconstruction of medical reality. New York: Routledge.

3. Atkinson P, Pugsley L. 2005. Making sense of ethnography and medical education. Med Educ. 39(2):228-234.

4. Balmer DF, Master CL, Richards B, Giardino AP. 2009. Implicit versus explicit curricula in general pediatrics education: is there a convergence? Pediatrics. 124(2):e347-e354.

5. Barkhuus L, Polichar VE. 2011. Empowerment through seamfulness: smart phones in everyday life. Pers Ubiquit Comput. 15(6):629-639.

6. Beddall-Hill N, Jabbar A, Al Shehri S. 2011. Social mobile devices as tools for qualitative research in education: iPhones and iPads in ethnography, interviewing, and design-based research. J Res Center Educ Technol. 7(1):67-90.

7. Browne G, O'Reilly D, Waters C, Tummon O, Devitt D, Stewart B, O'Connor P. 2015. Smart-phone and medical app use amongst Irish medical students: a survey of use and attitudes. BMC Proc. 9(Suppl 1):A26-A26.

8. Burr V. 1998. Overview: realism, relativism, social constructionism and discourse. In: Social constructionism, discourse and realism. London (UK): Sage; p. 13-26.

9. Clandinin DJ, Cave MT, Berendonk C. 2017. Narrative inquiry: a relational research methodology for medical education. Med Educ. 51(1):89-96.

10. Crozier SE, Cassell CM. 2016. Methodological considerations in the use of audio diaries in work psychology: adding to the qualitative toolkit. J Occup Organ Psychol. 89(2):396-419.

11. Dorsey ER, Yvonne Chan Y-F, McConnell MV, Shaw SY, Trister AD, Friend SH. 2017. The use of smartphones for health research. Acad Med. 92(2):157-160.

12. European Research Council 2017. ERC Data Management Plan

13. Template. [accessed 2019 Jul 30]. https://erc.europa.eu/content/ercdata-management-plantemplate.

14. Fisher CD, Noble CS. 2004. A within-person examination of correlates of performance and emotions while working. Hum Perform. 17(2): 145-168.

15. Fox AB, Rosen J, Crawford M. 2009. Distractions, distractions: does instant messaging affect college students' performance on a concurrent reading comprehension task? Cyberpsychol Behav. 12(1): 51-53.

16. Garcia B, Welford J, Smith B. 2016. Using a smartphone app in qualitative research: the good, the bad and the ugly. Qual Res. 16(5): 508-525.

17. Gordon L, Jindal-Snape D, Morrison J, Muldoon J, Needham G, Siebert S, Rees C. 2017. Multiple and multidimensional transitions from trainee to trained doctor: a qualitative longitudinal study in the UK. BMJ Open. 7(11):e018583.

18. Halamka J. 2011. Order interrupted by text: multitasking mishap. [accessed 2019 Jan 4]. https:// psnet.ahrq.gov/webmm/case/257.

19. Health Facilities Scotland. 2008. Guidance on the use of Mobile Communication Devices in healthcare premises. [accessed 2019 Jan 2]. http://www.hfs.scot.nhs.uk/publications/1479818380Mobile. Communications in Healthcare Premises (for web) v1.0.pdf.

20. Hein W, O'Donohoe S, Ryan A. 2011. Mobile phones as an extension of the participant observer's self: reflections on the emergent role of an emergent technology. Qualitative Mrkt Res An Int J. 14(3): 258-273. 
21. Holloway I, Biley FC. 2011. Being a qualitative researcher. Qual Health Res. 21(7):968-975.

22. John B. 2018. Are you ready for General Data Protection Regulation? BMJ. 360:k941.

23. Katz-Sidlow RJ, Ludwig A, Miller S, Sidlow R. 2012. Smartphone use during inpatient attending rounds: prevalence, patterns and potential for distraction. J Hosp Med. 7(8):595-599.

24. Koehler N, Yao K, Vujovic O, McMenamin C. 2012. Medical students' use of and attitudes towards medical applications. Mob Technol Med. 1(4):16-21.

25. Lally V, Sharples M, Tracy F, Bertram N, Masters S. 2012. Researching the ethical dimensions of mobile, ubiquitous and immersive technology enhanced learning (MUITEL): a thematic review and dialogue. Interact Learn Environ. 20(3):217-238.

26. Lingard L. 2007. Qualitative research in the RIME community: critical reflections and future directions. Acad Med. 82(10 Suppl): S129-S130.

27. Lynn P, Kaminska O. 2013. The impact of mobile phones on survey measurement error. Publ Opin Quart. 77(2):586-605.

28. MacLeod A, Ajjawi R, Cameron P, Kits O, Tummons J. 2009. Actor network theory and ethnography: sociomaterial approaches to researching medical education. Perspectives on Medical Education. 8(3):177-186.

29. MacLeod A, Kits O, Whelan E, Fournier C, Wilson K, Power G, Mann K, Tummons J, Brown PA. 2015. Sociomateriality: a theoretical framework for studying distributed medical education. Acad Med. 90(11): 1451-1456.

30. Mann K, Gordon J, MacLeod A. 2009. Reflection and reflective practice in health professions education: a systematic review. Adv Health Sci Educ Theory Pract. 14(4):595-621.

31. Masters K, Ellaway RH, Topps D, Archibald D, Hogue RJ. 2016. Mobile technologies in medical education: AMEE Guide No. 105. Med Teach. 38(6):537-549.

32. Maudsley G, Taylor D, Allam O, Garner J, Calinici T, Linkman K. 2019. A Best Evidence Medical Education (BEME) systematic review of: What works best for health professions students using mobile (handheld) devices for educational support on clinical placements? BEME Guide No. 52. Medical Teacher. 41(2):116-125.

33. McBride DL. 2015. Distraction of clinicians by smartphones in hospitals: a concept analysis. J Adv Nurs. 71(9):2020-2030.

34. Monrouxe LV. 2009. Negotiating professional identities: dominant and contesting narratives in medical students' longitudinal audio diaries. Curr Narratives. 1(1):41-59.

35. Mosa ASM, Yoo I, Sheets L. 2012. A systematic review of healthcare applications for smartphones. BMC Med Inform Decis Mak. 12(1):67.

36. Ng SL, Kinsella EA, Friesen F, Hodges B. 2015. Reclaiming a theoretical orientation to reflection in medical education research: a critical narrative review. Med Educ. 49(5):461-475.

37. Official Journal of the European Union. 2016. Regulation (EU) 2016/679 of the European Parliament and of the Council of 27 April 2016 on the protection of natural persons with regard to the processing of personal data and on the free movement of such data, and repealing Directive 95/46/EC (General Data Protection Regulation). In: Union OJotE, editor. Brussels.

38. Oppenheim AN. 2000. Questionnaire design, interviewing and attitude measurement. UK: Bloomsbury Publishing.

39. Papadakos PJ, Bertman S. 2017. Distracted doctoring: returning to patient-centered care in the digital age. Germany: Springer International Publishing.

40. Patel RK, Sayers AE, Patrick NL, Hughes K, Armitage J, Hunter IA. 2015. A UK perspective on smartphone use amongst doctors within the surgical profession. Ann Med Surg. 4(2):107-112.

41. Raiman L, Antbring R, Mahmood A. 2017. WhatsApp messenger as a tool to supplement medical education for medical students on clinical attachment. BMC Med Educ. 17(1):7. 
42. Ramesh J, Carter A, Campbell M, Gibbons N, Powlett C, Moseley H, Sr Lewis D, Carter T. 2008. Use of mobile phones by medical staff at Queen Elizabeth Hospital, Barbados: evidence for both benefit and harm. J Hosp Infect. 70(2):160-165.

43. Redlich-Amirav D, Higginbottom G. 2014. New emerging technologies in qualitative research. Qual Rep. 19(26):1-14.

44. Reeves S, Peller J, Goldman J, Kitto S. 2013. Ethnography in qualitative educational research: AMEE Guide No. 80. Med Teach. 35(8): e1365-e1379.

45. The University of Alabama at Birmingham. 2016. HIPAA core policy: use of portable devices. [accessed 2018 Dec 30]. https://www.uab. edu/policies/content/Pages/UAB-AD-POL-0000728.aspx.

46. Valle J, Godby T, Paul DP, Smith H III, Coustasse A. 2017. Use of smartphones for clinical and medical education. Health Care Manag (Frederick). 36(3):293-300.

47. Wu RC, Tzanetos K, Morra D, Quan S, Lo V, Wong BM. 2013. Educational impact of using smartphones for clinical communication on general medicine: more global, less local. J Hosp Med. 8(7): 365-372. 


$$
7
$$




\section{General Discussion}


What did you learn from the last major transition you had at work or in your personal life? What challenges did you encounter? In what way were those challenges detrimental? What made you more or less likely to have meaningful growth as a result of navigating that change?

Transitions are critically intensive learning periods (CILPS) ${ }^{1}$ that are both a threat and an opportunity for medical trainees to learn and develop². Many medical educators consider the transition to clinical training as a 'problem' to be minimised and solvedthis is the transition-as-problematic perspective ${ }^{3}$. However, medical educators cannot eliminate the gap between the two training phases. Transitions are inevitable, and there is a need to reframe transition discourse ${ }^{4}$ and identify new transition outcomes beyond student satisfaction ${ }^{5}$. Medical education researchers are increasingly highlighting the opportunities inherent in periods of change and adaptation that can lead to learning and development ${ }^{2,4-7}$. Such reframing is necessary to advance transition research and practice, and optimise transition interventions to better support trainees adapting to change. This thesis results from a research agenda developed with the primary aim: to enhance our understanding of how undergraduate medical students navigate the transition from pre-clinical to clinical training using sociocultural lenses. To meet this aim, we answered the following research questions: 1) In what ways does the transition from pre-clinical to clinical training contribute to medical students' professional and personal identity development? (Chapters Three and Five) 2) What role do social relationships play in students' transition from pre-clinical to clinical training? (Chapters Four and Five). This chapter will highlight how we contribute to a better understanding of how students navigate the transition from pre-clinical to clinical training. We will first discuss what we learned in this body of work and relate this to existing literature. Then, we discuss the implications of our findings for practice and research and lastly, we consider the strengths and weaknesses of our research approaches

\section{Contribution to the health professions education literature}

We explored the phenomenon of students transitioning from pre-clinical to clinical training from multiple conceptual lenses. These lenses relate to sociocultural learning theory from thinkers who considered that knowledge is based on social interaction ${ }^{8}$. Using this lens to view participative medical education was illuminating ${ }^{9,10}$. We used sensitising concepts from landscapes of practice, social networks and organisational socialisation to understand the transition to clinical training in unique, yet complementary ways. We now focus on two main conclusions from our data within two new perspectives to the familiar 'problem' of students navigating this transition period.

\section{A developmental perspective on the transition to clinical training}

We add to the literature an explicit consideration of student identity formation as it occurred when students went from being pre-clinical students to becoming clinical 
students working and learning around patients. Student identity formation is underrepresented in the literature and importantly, is distinct from professional identity formation ${ }^{11}$. Research embracing the developmental side of transitions acknowledges the challenges inherent in transitions and used reflection and empowerment strategies to help students adapt to change ${ }^{6}$. Through a sociocultural lens of work by Wenger et al., our qualitative longitudinal study (Chapter Three) shed light on the presence of students' positive and negative emotions during the transition from pre-clinical to clinical training. Using research poetry in Chapter Three to analyse and present data allowed us to authentically share the emotional charge inherent when students transition to clinical training and the identity work that exists. In Chapter Three, we answer Hodson's call for empirical work on medical education in landscapes of practice, and identity formation through membership of multiple communities ${ }^{9}$. Like authors in the Netherlands ${ }^{12}$, we found evidence of Wenger's three modes of identification that describe how newcomers develop an identity as they participate in a new learning environment-engagement, imagination and alignment $^{10}$. Within this frame ${ }^{10}$, we found evidence of professional and personal development as students learned to be proactive about their learning (see also Chapter Five), finding role models and developing a journey mindset, all. At the same time, they frequently transitioned to new learning environments (e.g. clerkships). We echo Wenger that the transition, cross that boundary into a new clerkship space, is where clinical students learned new skills and knowledge; they developed ${ }^{9,10}$. Therefore, rather than assuming that learning occurs only when students enter a new clerkship and aim to be a fully participating member, we recognise that transition periods, boundaries, are a 'place where novel learning and growth arises ${ }^{\prime 9}$. We inadvertently conducted a transition intervention by having students reflect throughout their transition journey; they became active participants in their identity formation ${ }^{13,14}$. Other authors found that reflective exercises toward the end of pre-clinical training helped students recognise critical experiences ${ }^{15-17}$, promoted professional development ${ }^{15}$, and reframed their experiences towards becoming the type of doctor they wanted to be ${ }^{16}$.

Wenger-Trayner has posited that 'the $21^{\text {st }}$ century will be the century of identity' ${ }^{\prime 18}$. We found evidence of student identity development as students transitioned to clinical learning, and work, spaces. In this way, crossing borders and becoming transient members of multiple communities contributed to students' identity formation in a meaningful, transformational way ${ }^{9}$. Hodson suggests that future doctors will need to possess skills to navigate the changing landscape of knowledge and respond to unpredictable challenges ${ }^{9}$. We contribute to this thinking by highlighting that while proactive behaviour is one necessary skill for entering a new environment, institutions must ensure this environment is psychologically safe to support proactivity. 
In Chapter Five, we describe how students felt concerning their tendency to be proactive about seeking feedback and information, negotiating day to day tasks and building relationships with those in the clinical environment. Proactive behaviour was affected by individual and team- and system-level factors. Authors in other fields suggest training can develop transition skills such as proactive behaviour. However, focusing on optimising the environment, so students feel safe to be proactive is crucial. Proactivity is desirable behaviour, and faculty often reward proactive students with attention and teaching ${ }^{19}$. Organisational socialisation authors gave us a framework to examine proactivity in Chapter Five. In return, we have expanded their conceptualisation of the predictors for and antecedents for proactive behaviour in a medical context. Previously, the main proactive behaviours implicitly explored in medical education are speaking up $^{20}$ and feedback-seeking ${ }^{21}$. We now add that negotiating tasks is difficult for most clinical students especially when in a new environment but even more importantly, that proactivity is not an individual construct but is heavily influenced by social factors.

\section{A social perspective on the transition to clinical training}

We also add the literature an embrace of the social side of transitions. By tapping into Wenger-Trayner's landscape of practice model ${ }^{10}$, in Chapter Four, we explained how students' social networks change over time in part due to their journey across the borders separating clerkship communities ${ }^{9,10,22}$. We are the first to highlight transitioning medical students' social network structures and how these structures change over time. Embracing a qualitative approach to social network analysis in Chapter Four allowed us to find that students deliberately created, kept and dissolved relationships based on whether they thought the relationship served them with emotional or instrumental support. Social network theory provided us with both a methodology and a lens to examine transitioning students' networking choices and implications as they enter the clinical side of medicine. Social network theory provided some explanatory power for our findings. Social network theory offered us a concept of network intentionally ${ }^{23}$ to add weight to this finding. We found that networks changed significantly, even just over five months of being in clerkships. Networks were not static. By considering tie churn - stability and change in networks over time ${ }^{24}$ - we offer that during the transition to clinical training, relationships are created, kept or dropped but this does

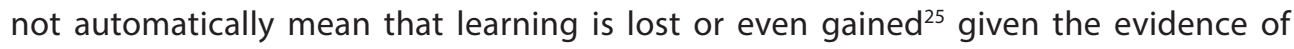
individual development in Chapters Three and Five.

In Chapter Five, we found that although students ultimately become socially integrated, this process can be more difficult if they have a negative mindset and feel intimidated by those above them in the medical hierarchy. Students' tendency to exhibit proactive behaviour was indeed a result of their social network and a particular clerkship's learning environment. The hierarchy in medicine, especially limited their propensity to 
negotiate their clinical tasks and initiate relationship-building with consultant doctors. Importantly, we also gained insight into how members of students'networks can become role models that affect their identity development ${ }^{22}$ (Chapter Three). Social network theory argues that individual behaviour is a result of social connections ${ }^{26}$. Therefore, we believe that proactive behaviour is a social construct; students' social networks in the clinical environment impact how proactive they might be. Network members can cultivate a safe learning environment where students feel motivated and capable of being proactive about their learning and build meaningful relationships (Chapter Five).

\section{Strengths and limitations}

Using the aforementioned conceptual frameworks to explore the student experience navigating the transition to clinical training is innovative. Still, our research choices also allowed us to contribute to the medical education field conceptually and methodologically. A scoping review allowed us to take a bird's eye view of the literature on the transition to clinical training and zoomed in on the existing conceptualisations of this transition in the field. This review allowed us to highlight gaps in the field to answer in this programme of research. Following students from pre-clinical training through their transition to clinical training, as they were experiencing, it adds authentic insight into how they navigate change. This methodology allowed us to see students' welldocumented struggles, eureka moments and shift to a journey mindset that was part of identity development; students progressed through five months of clinical clerkships (Chapter Two). Using smartphones facilitated this research choice perfectly allowing us access to participants in a non-intrusive way. Our decision to use smartphones as a research tool led us to create a concrete artefact (Chapter Six) that offers the field a critical appraisal of using technology to collect rich qualitative data. Further, using research poems - poems created from transcripts - to analyse, interpret and present data from the longitudinal study (Chapter Three) allows us to be the first to contribute a vibrant, yet accurate representation of students' experience of becoming a 'student doctor' according to our participant David. Lastly, using mixed methods to unpack the construct of proactivity will hopefully offer the field insight into the social aspect of proactivity.

We recognise some limitations of our research decisions and processes. The sample sizes in chapters three and four were relatively small due to our intense research methods, limiting the transferability of our results ${ }^{27}$. Secondly, Chapter 4 could have benefited from more extended data collection period. However, we considered constraints regarding the PhD timeline. Thirdly, all of our studies only used medical students as participants. It would be essential to investigate the perspectives of clerkship directors and the groups mentioned in participants' networks regarding their influence on students' development and network development. 


\section{Implications for practice and research}

The transition to clinical training is both a threat and an opportunity for learning and development. Students' lived reality of this dichotomy is depended on educators' perspective shifts and creating a supportive environment for the transitioning student. These changes can take the field toward meaningful transition strategies and research.

\section{Implications for practice}

Completing regular audio-diaries about their lived experiences over nine months helped our participants in Chapter Three recognise critical experiences and growth. They realised that changing their mindset was key to becoming more positive and having a meaningful transition experience through reflection. Therefore, medical students could find it beneficial to reflect on their lived experiences during any transition phase. Specifically, using smartphones to reflect is an efficient way to reflect.

We found countless examples of students' family members being outlets for conscious reflection and venting about their day-to-day experiences. Venting provided the necessary emotional support for students. Family members should be aware of the role they play on the development of their loved ones. Healthcare and educational institutions also have a role to play. Some students in our studies used the transcripts from their audio-diaries, and the research poems we sent them, as an entry in their institutional portfolios. Institutions could consider being flexible in how students submit portfolios and giving reflective space for medical students. Two students in the longitudinal study had psychological distress requiring time off, although the institution facilitated this needed break from them. It could be illuminating to look at the social factors that could have contributed to this distress (e.g. the environment's psychological safety).

Students' explicit reflection of their social networks was illuminating for them. Medical institutions could consider this an activity where students can draw their social networks and reflect on them; this could alert students to the meaningful relationships they can rely on for emotional and instrumental support during the challenging transition phase. Having students complete social network diagrams could alert institutions to the practical brokers in their institutions - the individuals who help newcomers adapt to the clinical space. Sometimes these brokers included near-peer medical students. Transitioning medical students often leaned on near-peer students, especially at the beginning of the transition period; both near-peer students and institutions should consider this trend. Near-peers have their development and learning to manage, which led to limited time to offer support to transitioning medical students. Brokers themselves could require support and the institution could consider offering brokers protected time to administer support to those who naturally come to them. 


\section{Implications for future research}

When students described their social networks in Chapter Four, we found limited relationships between transitioning students and other health professionals like nurses and physiotherapists. Interestingly, some students felt more capable of being proactive around nurses, for example, as compared to junior or senior doctors. Future research could explore interprofessional relationships' influence on students' behaviour, especially when adapting to a new clinical environment. We acknowledge the social impact on this transition period and future research could involve 'others' in the clinical community to gain insight into how groups in students' social networks perceive they influence students' transition experiences.

Students deliberately curated their social support networks, and we found that these networks created an environment that either stimulated or hindered individual behaviour like proactivity. Therefore, exploring the association between network development, as a social outcome of transitioning, and a sense of social integration and students' performance in clinical experiences could be a practical next step.

Future research could continue introducing technology to collect data in transition research, given the just-in-time capabilities that allow insight as the transition is occurring. Students in our studies sometimes alluded to how having coffee breaks, and lunches with clinical team members made them feel included as a part of the team. Ethnographers found that corridors in hospitals created a space where the hierarchy and the 'rules' of patient procedures disappeared and where open conversations could occur between inter-professionals ${ }^{28}$ Similarly, transition research could benefit from observations in the field.

Additionally, observing clinical team members' creation of a psychologically safe or unsafe learning space could be illuminating as we explore social influences on developmental skills such as proactive behaviour. These suggestions could take researchers beyond students' perspectives ${ }^{5}$ and give concrete insight into the lived reality of transitions related to how new clinical students interact with clinical spaces and the impact this has on them and the impact they have on the clinical environment.

\section{Reflexivity}

I was the primary researcher in all studies in this programme of research. However, working with supervisors and researchers from different backgrounds-clinicians, educational researchers, designers and leaders - helped me challenge my current thinking about transitions. Together with participants' data, these backgrounds led to the interpretations the reader meets in this thesis. The methodological choices of conducting a longitudinal qualitative study over nine months and having face-to-face 
interviews with participants reflecting on their social support network privileged me to develop an intense researcher-participant relationship with most participants. I am not oblivious that this could be a negative, yet unintentional outcome of this research but I, and my supervisors, believe this was an asset. I became a third party in whom many participants confided and used as a 'sounding board' for their day-to-day experiences, positive or negative, as they transitioned to clinical training. For this reason, I believe this relationship allowed me insight into students' transition that would not have been accessed had I used other data collection methods and study durations.

I am the product of many transitions-professional, geographical and psychological. As I experienced my transitions, and wrote in my research diary, some of my opinions changed. My transition experience moving to new cities that were 7,149 km (Maastricht) and 16,156 km (Sydney) away from my home in Barbados, threatened my psychological health. However, these experiences were equally an opportunity for my personal and professional development. I gained experience in problem-based-learning and resolved significant interpersonal conflict in my PBL group with confidence and grace. I battled substantial bouts of anxiety stimulated by a high cost of living in Sydney and being away from home. In talking through and reflecting my everyday life, I began to appreciate the challenge. Still, as my research progressed, I realised that I was only able to do this because of the extensive social support network I have deliberately selected over the past thirty-four years. My research and mindset blossomed almost simultaneously as I realised a transition is both an opportunity and a threat, depending on the level of support received by a medical student. I hope that readers acknowledge that this book results from my own complex identity, created across a complicated landscape of medical and research practice, and has multi-membership in innumerable communities. I am the result of all my experiences, emotions, papers, discussions, coffee talks, dinners, workshops, conferences that I encountered in my career thus far as a health professions educator and researcher.

\section{Final thoughts}

In this thesis, we now have an enhanced understanding of the scope of medical education research regarding the transition to clinical training. Specifically, we found that most medical education researchers have a negative, problematic perspective on the transition to clinical training. Researchers approach the transition to clinical training from an educational perspective leading them to create strategies to prepare students for clinical training by teaching them knowledge and skills ahead of their first clerkship experience. Fewer researchers and educators consider the social and development perspectives to the transition to clinical training which would acknowledge and address the social influences on students'transition experiences and the personal developmental growth that is inevitable. The transition to clinical training is an opportunity for identity 
and lifelong skills development and social network development and utilisation. The transition to clinical training is a time of deliberate curation of students' social support networks which provide emotional and instrumental support. These networks contribute to nurturing learning environments where students can experience psychological safety that allows them to be vulnerable while being proactive about their learning and development. Using technology helped us to meet our research agenda by providing an avenue to facilitate data collection while students were transitioning. We are confident we met our research agenda but acknowledge that there is much more work to do in unpacking the opportunities inherent in all transitions in medical training while cultivating meaningful strategies to help trainees adapt to change.

Transitions can be stressful and will always present a threat to medical students' learning and development. Shifting transitions towards being an opportunity for empowerment and growth could be achieved by allowing students to live through their transitions by offering them space to reflect, making their support networks visible, and creating awareness for clinical team members of their influence.

Based on the information presented in this entire thesis, we believe that Instead of focusing on the 'struggles' inherent in transition phases, we recommend that researchers and educators accept that transitions are a challenge and an opportunity for significant development. Additionally, we agree that boundaries, including between pre-clinical and clinical training, are a learning asset ${ }^{10}$; 'boundaries are the places where novel learning and growth arise ${ }^{\prime 9}$. We found that the boundary surrounding the clinical environment, and other specific clerkship communities, was where learners developed networking skills and exhibited proactive behaviour and gradually developed mindset shifts. While the transition to clinical training and other medical education transitions are known as critically intensive learning period (CILPs) ${ }^{1}$, we found that this transition is also crucial for networking. Rather than focusing on transitions as time-bound 'problem', using terms like 'period' and 'struggle', we consider it important to focus on the inherent developmental opportunities that transitions incur. We suggest the transition to clinical training could, in fact, a developing and networking asset once systems demand supportive learning environments. A place where, personal and professional development occurs, heavily dependent on students' social networks. By looking beyond the 'struggles' of the transition to clinical training, we can create interventions that privilege space for students to live, reflect on, and be supported by educational and healthcare institutions. 


\section{REFERENCES}

1. Kilminster S, Zukas M, Quinton N, Roberts T. Preparedness is not enough: Understanding transitions as critically intensive learning periods. Medical education. 2011;45(10):1006-1015.

2. Teunissen PW, Westerman M. Opportunity or threat: The ambiguity of the consequences of transitions in medical education. Medical education. 2011;45(1):51-59.

3. Gravett K. Troubling transitions and celebrating becomings: From pathway to rhizome. Studies in Higher Education. 2019:1-12.

4. O'Brien BC. What to do about the transition to residency? Exploring problems and solutions from three perspectives. Academic Medicine. 2018;93(5):681-684.

5. Yardley S, Westerman M, Bartlett M, Walton JM, Smith J, Peile E. The do's, don't and don't knows of supporting transition to more independent practice. Perspectives on medical education. 2018;7(1):8-22.

6. Atherley A, Dolmans D, Hu W, Hegazi I, Alexander S, Teunissen PW. Beyond the struggles: A scoping review on the transition to undergraduate clinical training. Medical education. 2019;53(6):559-570.

7. Gordon L, Jindal-Snape D, Morrison J, et al. Multiple and multidimensional transitions from trainee to trained doctor: A qualitative longitudinal study in the uk. BMJ open. 2017;7(11):e018583.

8. Prawat RS. Constructivisms, modern and postmodern. Educational psychologist. 1996;31(3-4):215225.

9. Hodson N. Landscapes of practice in medical education. Medical Education. 2020;54(6):504-509.

10. Wenger-Trayner E, Fenton-O'Creevy M, Hutchinson S, Kubiak C, Wenger-Trayner B. Learning in landscapes of practice: Boundaries, identity, and knowledgeability in practice-based learning: Routledge; 2014.

11. Balmer DF, Teunissen PW, Devlin MJ, Richards BF. Stability and change in the journeys of medical trainees: A 9-year, longitudinal qualitative study. Academic Medicine. 2020.

12. Adema M, Dolmans DHJM, Raat J, Scheele F, Jaarsma ADC, Helmich E. Social interactions of clerks: The role of engagement, imagination, and alignment as sources for professional identity formation. Academic Medicine. 2019;94(10):1567-1573.

13. Cruess RL, Cruess SR, Boudreau JD, Snell L, Steinert Y. A schematic representation of the professional identity formation and socialization of medical students and residents: A guide for medical educators. Academic Medicine. 2015;90(6):718-725.

14. Monrouxe LV. Identity, identification and medical education: Why should we care? Medical education. 2010;44(1):40-49.

15. Pitkala K, Mantyranta T.Professional socialization revised: Medical students' own conceptions related to adoption of the future physician's role--a qualitative study. Medical teacher. 2003;25(2):155-160.

16. Soo J, Brett-MacLean P, Cave MT, Oswald A. At the precipice: A prospective exploration of medical students' expectations of the pre-clerkship to clerkship transition. Adv Health Sci Educ Theory Pract. 2016;21(1):141-162.

17. Jacobs JCG, Bolhuis S, Bulte JA, Laan R, Holdrinet RSG. Starting learning in medical practice: An evaluation of a new introductory clerkship. Medical Teacher. 2005;27(5):408-414.

18. Wenger E. Knowledgeability in landscapes of practice: From curriculum to identity. Presentation given at the given at the. Society for Research into Higher Education. 2010.

19. Stalmeijer RE, Dolmans DH, Snellen-Balendong HA, van Santen-Hoeufft M, Wolfhagen IH, Scherpbier AJ. Clinical teaching based on principles of cognitive apprenticeship: Views of experienced clinical teachers. Academic Medicine. 2013;88(6):861-865. 
20. Voogt JJ, Taris TW, van Rensen EL, Schneider MM, Noordegraaf M, van der Schaaf MF. Speaking up, support, control and work engagement of medical residents. A structural equation modelling analysis. Medical education. 2019;53(11):1111-1120.

21. McGinness HT, Caldwell PH, Gunasekera H, Scott KM. An educational intervention to increase student engagement in feedback. Medical Teacher. 2020;42(11):1289-1297.

22. Atherley A, Nimmon L, Teunissen PW, Dolmans D, Hegazi I, Hu W. Students' social networks are diverse, dynamic and deliberate when transitioning to clinical training. Med Educ. 2020;n/a(n/a).

23. Moolenaar NM, Daly AJ, Cornelissen F, et al. Linked to innovation: Shaping an innovative climate through network intentionality and educators' social network position. Journal of educational change. 2014;15(2):99-123.

24. Murphy E, Nicholl J. Three techniques for integrating data in mixed methods. BMJ. 2010;341:c4587.

25. Van Waes S. The ties that teach: Teaching networks in higher education: University of Antwerp; 2017.

26. Butts CT. Carrington, pj, scott, j., wasserman, s., 2005. Models and methods in social network analysis. Cambridge: Cambridge university press: North-Holland; 2007.

27. Malterud K, Siersma VD, Guassora AD. Sample size in qualitative interview studies: Guided by information power. Qualitative health research. 2016;26(13):1753-1760.

28. ledema R, Long D, Carroll K. Corridor communication, spatial design and patient safety: Enacting and managing complexities. Organizational spaces: Rematerializing the workaday world. 2010:4157. 

Summary 


\section{Chapter One}

This PhD thesis began by considering whether the transition to clinical training is an opportunity or a threat to medical students' personal and professional development. The literature is littered with evidence mainly portraying the threats to personal and professional development that the transition to clinical education can bring. We first described the origin of transitions in medical training, then we shared a brief literary debate regarding whether a transition is an opportunity or a threat to personal and professional development and existing transition interventions. Recently, authors have called for new perspectives on transitions in medical training. Therefore, we sought to enhance our understanding of how undergraduate medical students navigate the transition from pre-clinical to clinical training using sociocultural lenses (e.g., landscapes of practice, social network theory and organisational socialisation). To meet this aim, we first conducted a scoping review (Chapter Two) exploring how researchers have approached the transition from pre-clinical to clinical training and identified the gaps in these approaches. From this review, we determined what empirical studies were necessary and created a research agenda to advance evidence and contribute to the development of meaningful strategies to help students navigate change. Our subsequent research questions were: 1 ) In what ways does the transition from pre-clinical to clinical training contribute to the professional and personal identity development of medical students? [Answered by Chapters 3 and 5] 2) What role do social relationships play in students' transition from pre-clinical to clinical training? [Answered by Chapters 4 and 5]

\section{Chapter Two}

Chapter Two reflects the aforementioned scoping review conducted to 1) explore the existing conceptual perspectives regarding the undergraduate transition from preclinical training to clinical training and 2) suggest a research agenda with practical implications. We included 46 articles from five electronic databases. We found that the transition to clinical training was often described negatively — "difficult", "a problem", and "a struggle". Further, we found that researchers in medical education conducted studies on the transition to clinical training from three conceptual perspectives: educational, social and developmental. Most research approached the transition to clinical training as a problem to be addressed from an educational perspective through transition to clerkship courses and curriculum innovations. Some research was conducted from a social perspective focusing on building relationships. Regarding development, we found a few articles highlighting opportunities for personal and professional development by nurturing transferrable learning strategies and reflection. Our findings provided an empirical base for future research to better understand and support students' ability to navigate change. Using social and developmental perspectives to explain and support the transition to clinical training is likely promising as this could help researchers to look beyond preparing students for the struggles of transitions in medical training. 


\section{Chapter Three}

The scoping review in Chapter Two identified that developmental perspectives to the transition to clinical training could be useful to focus on student empowerment and transferrable learning behaviours. In Chapter Three, we made visible student identity formation (as opposed to professional identity formation) and explored research question 1 (RQ1) above. In this chapter, we aimed to explore how nine $2^{\text {nd }}$ year medical students narrated their navigation of the transition from pre-clinical to clinical training and their student identity development. Students generated 61 reflective entries comprising of audio-diary (or typed) submissions over nine months (starting three months before clinical clerkships began) and two interviews. Research poems (transcripts reframed as poetry) helped us construct a meaningful, emotive elicitation of our longitudinal data and analysed data using sensitising concepts from Wenger's modes of identification: engagement, imagination and alignment. We found that students described their transition as a journey filled with positive and negative emotions and uncertainty about their current and future career. Students in our sample contributed to their developing student identity using three mechanisms: 1) becoming more engaged by taking charge, 2) shaping their image of self through engagement and finding role models; and 3) learning to flexibly adapt to clerkship norms by managing expectations and adopting a journey mindset. Students accepted the ups and downs that they experienced and stated that the act of reflecting in this study was beneficial to their experiences. These results suggest that instead of seeking smooth transitions, transitions should be lived, reflected on and supported. To answer our RQ1, we found that, during the transition to clinical training, students' professional identity development occurs through students being proactive, shaping their self-image and developing a journey mindset.

\section{Chapter Four}

The scoping review in Chapter Two identified that social perspectives to the transition to clinical training could be useful to focus on the influence that relationships have on student' transition experiences and learning. In Chapter Four, we used qualitative, social network research methods to explore social relationships and support as medical students transitioned from pre-clinical to clinical training and explored research question 2 (RQ2) above. Eight medical students completed a social network map during a semi-structured interview within two weeks of beginning their clinical clerkships $\left(T_{0}\right)$ and then again four months later $\left(T_{1}\right)$. Students then indicated meaningful interactions that influenced their transition from pre-clinical to clinical training and discussed how these relationships (ties) impacted their transition. We conducted mixed-methods analysis on this data. At $T_{0^{\prime}}$ eight participants described the influence of 128 people in their social support networks; this marginally increased to 134 at $\mathrm{T}_{1}$. People from within and beyond the clinical space made up participants' social networks. As new relationships were created (e.g., with peers and doctors), old relationships were kept 
(e.g., with doctors and family) or dissolved over time (e.g., with near-peers and nurses). Participants deliberately created, kept or dissolved relationships over time dependent on whether they provided emotional support (e.g., they could trust them) and/or instrumental support (e.g., they provided academic guidance). These findings provide insight into how social relationships are created, maintained and dissolved during the transition to clinical training. We found that this transition is also a. To answer our RQ2, we found that the transition to clinical training is a critically intensive networking period as students developed and refined their social networks over the transition period. Students deliberately curated social networks are diverse and dynamic over time.

\section{Chapter Five}

The transitions literature and the study in Chapter Three identified the construct 'proactivity' as a skill which augments students' learning and development during clinical training. We therefore explored 1) to what extent do clinical students exhibit proactive behaviours when entering a new clerkship and 2) the influential factors and the relationship between being proactive and feeling integrated socially into a new clerkship. Though this study intended to answer RQ 1 above, it also provided answers to RQ 2. This mixed-methods study included data from 200 participants and 18 individual interviews from $3^{\text {rd }}, 4^{\text {th }}$ and 5 th-year clinical students. Surveys explored five proactive socialisation behaviours: seeking feedback, seeking information, negotiating tasks and roles, having positive framing around new experiences and building relationships with others. While students generally were positive when entering a new clerkship, they found it challenging to negotiate tasks. More senior ( $4^{\text {th }} \& 5^{\text {th }}$ year) clinical students were less proactive than novice ( $3^{\text {rd }}$ year) students. We found three antecedents to being proactive as a clinical student in a new clerkship: intention to be proactive, feeling capable of being proactive and being in an environment supporting proactivity. Individual factors influenced the intention to be proactive, social factors curated an environment that supported proactivity, and both individual and social factors affected students' capability of being proactive. Lastly, having positive framing about new experiences when entering a new clerkship was associated with social integration. These findings suggest that supporting and encouraging proactive socialisation behaviours, especially in senior clinical students, could potentially enhance social integration into the clinical environment. To answer our overarching research questions, this Chapter revealed that proactive behaviour is a developmental skill that contributes to both personal and professional development. Further, proactive behaviour is a social construct influenced heavily by team members and healthcare and educational systems.

\section{Chapter Six}

In Chapter Six, we share an evidenced-based reflection on using smartphones to collect qualitative data in medical education. This chapter was borne out of our realisation that 
most prior transition literature used cross-sectional study designs. These prior research approaches yielded the potential for recall bias given that they collected data before or after students had 'transitioned' to a new environment. Smartphone use is ubiquitous in many aspects of health - patient management, education and health research. We aimed to provide guidance to design, conduct and reflect on the use of smartphones in medical education research (MER). It is critical for researchers to share experiences in the academic literature to facilitate global progression of research processes. We found that smartphones can enhance the research purpose and fits the principles of qualitative MER. Researchers must however be mindful of using smartphones in medical education research as they can affect the research data, threaten privacy and perpetuate distractions. We conclude that the intentional, use of smartphones in future MER is depended on researchers openly communicating with participants, being reflective and challenging institutional review boards to recognise their responsibility in monitoring the use of smartphones in MER.

\section{Chapter Seven}

In Chapter Seven, we answer our research questions as we synthesised and discussed our findings of all studies. In this body of work, we aimed to enhance our understanding of how undergraduate medical students navigate the transition from pre-clinical to clinical training using sociocultural lenses. Specifically, regarding our first research question (in what ways does the transition from pre-clinical to clinical training contribute to the professional and personal identity development of medical students?), we made visible the student identity formation and learned that this occurs through students being proactive, shaping their self-image and developing a journey mindset. In relation to our second research question (what role do social relationships play in students' transition from pre-clinical to clinical training?), we found that the transition to clinical training is an opportunity for the students' social network development and utilisation through deliberate curation of a dynamic network made of a diverse group of people. Our findings suggest that allowing students to live through their experiences by offering them space to reflect, making their support networks visible, and creating awareness for clinical team members of their influence could shift transitions to being an opportunity for students to move beyond the struggles of change toward empowerment and growth as they move on to another phase in their career. 



\section{Samenvatting}




\section{Hoofdstuk Één}

Dit proefschrift begon met de vraag of de overgang naar klinisch onderwijs een kans biedt of juist een bedreiging vormt voor de persoonlijke en professionele ontwikkeling van Geneeskundestudenten. De literatuur staat bol van bewijs dat voornamelijk de bedreigingen voor de persoonlijke en professionele ontwikkeling schetst die de overgang naar klinisch onderwijs met zich mee kan brengen. Eerst beschreven we de intrede van transities in de medische opleiding; vervolgens deelden we een kort literair debat over de vraag of een overgang een kans biedt of juist een bedreiging vormt voor de persoonlijke en professionele ontwikkeling en bespraken we bestaande transitieinterventies. Auteurs hebben onlangs opgeroepen tot nieuwe visies op transities in het medisch onderwijs. Daarom hebben we vanuit sociaal-culturele invalshoeken (zoals praktijklandschappen, sociaalnetwerktheorie en organisatiesocialisatie) getracht om meer inzicht te verkrijgen in hoe bachelorstudenten Geneeskunde bij de overgang van preklinisch naar klinisch onderwijs hun weg vinden. Om dit doel te bereiken, hebben we eerst een verkennende literatuurstudie (scoping review) uitgevoerd (Hoofdstuk 2) waarin we onderzochten hoe onderzoekers de overgang van preklinisch naar klinisch onderwijs hebben benaderd om vervolgens de discrepanties tussen deze benaderingen in kaart te brengen. Op basis van deze review bepaalden we welke empirische onderzoeken er nodig waren en stelden we een onderzoeksagenda op met het doel bewijs te presenteren en bij te dragen aan de ontwikkeling van zinvolle strategieën om studenten te helpen om te gaan met verandering. Onze volgende onderzoeksvragen waren: 1) Op welke wijze draagt de overgang van preklinisch naar klinisch onderwijs bij aan de ontwikkeling van een professionele en persoonlijke identiteit van Geneeskundestudenten? [Beantwoord door Hoofdstuk 3 en 5]; en 2) Welke rol spelen sociale relaties bij de overgang van preklinisch naar klinisch onderwijs door studenten? [Beantwoord door Hoofdstuk 4 en 5].

\section{Hoofdstuk Twee}

Hoofdstuk 2 geeft de voornoemde scoping review weer waarmee we poogden 1) de bestaande wetenschappelijke zienswijzen ten aanzien van de overgang van preklinisch onderwijs in de bacheloropleiding naar klinisch onderwijs te onderzoeken en 2) een onderzoeksagenda met gevolgen voor de praktijk voor te stellen. We includeerden 46 artikelen uit vijf elektronische databases. We constateerden dat de overgang naar klinisch onderwijs vaak werd beschreven als negatief, met woorden als "moeilijk", "een probleem" en "een strijd". Voorts vonden we dat onderzoekers in het medisch onderwijs de studies op het gebied van de overgang naar klinisch onderwijs hadden verricht vanuit drie wetenschappelijke zienswijzen, namelijk een onderwijskundige, maatschappelijke en ontwikkelingsgerichte zienswijze. In de meeste studies werd de overgang naar klinisch onderwijs beschouwd als een probleem dat vanuit een onderwijskundig perspectief moest worden aangepakt door over te stappen op coschapstrainingen en door middel van curriculumvernieuwingen. Enkele studies waren vanuit een maatschappelijke 
zienswijze verricht en richtten zich zodoende op het opbouwen van relaties. Met betrekking tot ontwikkeling vonden we een paar artikelen die de nadruk legden op de kansen voor persoonlijke en professionele ontwikkeling door het bevorderen van overdraagbare leerstrategieën en reflectie. Onze bevindingen boden een empirisch uitgangspunt voor toekomstig onderzoek dat beoogt beter te begrijpen in welke mate studenten in staat zijn om te gaan met verandering en hen daarbij te ondersteunen. We verwachten dat het hanteren van een maatschappelijke en ontwikkelingszienswijze voor het verklaren en ondersteunen van de overgang naar klinisch onderwijs veelbelovend is, omdat dit onderzoekers zou kunnen helpen om verder te kijken dan het voorbereiden van studenten op de moeilijkheden die transities in het medisch onderwijs met zich meebrengen.

\section{Hoofdstuk Drie}

De scoping review uit Hoofdstuk 2 wees uit dat het aannemen van een ontwikkelingszienswijze ten aanzien van de overgang naar klinisch onderwijs nuttig zou kunnen zijn omdat dit een focus op studentempowerment en overdraagbaar leergedrag mogelijk maakt. In Hoofdstuk 3 maakten we de vorming van een studentidentiteit (als tegenhanger van een professionele identiteit) zichtbaar en beantwoordden we onderzoeksvraag 1 (RQ1) hierboven. In dit hoofdstuk wilden we onderzoeken hoe negen tweedejaars Geneeskundestudenten hun beleving van de overgang van preklinisch naar klinisch onderwijs en de vorming van hun studentidentiteit beschreven. De studenten genereerden 61 reflecties bestaande uit audio- of getypte dagnotities gedurende een periode van negen maanden (met aanvang drie maanden vóór de start van de coschappen) en twee interviews. Met behulp van onderzoeksgedichten (tot poëzie herschreven transcripten) waren we in staat om op zinvolle en emotionele wijze onze longitudinale data te activeren. De data werden geanalyseerd aan de hand van richtinggevende begrippen (sensitising concepts) afkomstig van Wengers identificatiemethoden: betrokkenheid, verbeelding en aanpassing. Onze bevinding was dat de studenten hun overgang beschreven als een reis vol positieve en negatieve emoties en onzekerheid rondom hun huidige en toekomstige loopbaan. De studenten uit onze steekproef droegen middels drie mechanismen bij aan de ontwikkeling van hun studentidentiteit: 1) meer betrokken raken door het heft in eigen handen te nemen; 2) hun zelfbeeld vormen door betrokken te zijn en rolmodellen te zoeken; en 3) leren om zich flexibel aan te passen aan de coschapsregels door aan verwachtingen te voldoen en een reismindset aan te nemen. De studenten accepteerden de ups en downs die ze meemaakten en gaven aan dat het reflecteren in deze studie aan hun beleving ten goede kwam. Deze resultaten maken aannemelijk dat, in plaats van te streven naar vlotte transities, deze transities doorgemaakt moeten worden, erop gereflecteerd moet worden en deze ondersteund moeten worden. Als antwoord op RQ1 concludeerden we dat studenten gedurende de overgang naar klinisch onderwijs hun professionele 
identiteit vormen door proactief te zijn, hun zelfbeeld te vormen en een reismindset aan te nemen.

\section{Hoofdstuk Vier}

De scoping review uit Hoofdstuk 2 wees tevens uit dat het nuttig zou kunnen zijn met een maatschappelijke bril te kijken naar de overgang naar klinisch onderwijs, omdat dit een focus op de invloed van relaties op de beleving van deze overgang en het leren tijdens de overgang door studenten mogelijk maakt. In Hoofdstuk 4 gebruikten we kwalitatieve methoden voor sociaal-netwerkonderzoek om sociale relaties en ondersteuning te onderzoeken gedurende de overgang van preklinisch naar klinisch onderwijs door Geneeskundestudenten en beantwoordden we onderzoeksvraag 2 (RQ2) hierboven. Acht Geneeskundestudenten vulden binnen twee weken na de start van hun coschappen (T0) en vier maanden later nogmaals (T1) tijdens een semigestructureerd interview een sociaal-netwerkschema in. Vervolgens gaven de studenten aan welke contacten zinvol waren doordat deze hun overgang van preklinisch naar klinisch onderwijs beïnvloed hadden en bespraken zij hoe deze contacten (banden) van invloed waren geweest. We pasten een multimethodische analyse toe op de data. Bij T0 beschreven de participanten de invloed van 128 mensen uit hun sociaal ondersteuningsnetwerk; dit aantal was bij T1 licht gestegen naar 134. Het sociale netwerk van de participanten bestond uit mensen van binnen en buiten de klinische omgeving. Terwijl nieuwe contacten werden opgedaan (bijv. met coassistenten en artsen), werden gaandeweg oude contacten gehandhaafd (bijv. met artsen en familie) of verbroken (bijv. met meer ervaren coassistenten en verplegers). In de loop der tijd gingen de deelnemers doelbewust nieuwe contacten aan, behielden zij deze of verbraken zij deze al naargelang deze contacten emotionele ondersteuning (bijv. zij konden hen vertrouwen) en/of functionele (bijv. academische) ondersteuning boden. Deze bevindingen geven inzicht in hoe sociale contacten tijdens de overgang naar klinisch onderwijs worden aangegaan, behouden en verbroken. Als antwoord op RQ2 concludeerden we dat de overgang naar klinisch onderwijs een cruciale periode is van intensief netwerken, aangezien studenten tijdens deze overgangsperiode hun sociale netwerk opbouwden en verder vormgaven. De sociale netwerken die studenten doelbewust hebben opgebouwd zijn variabel en dynamisch in de tijd.

\section{Hoofdstuk Vijf}

In de literatuur over transities en de studie uit Hoofdstuk 3 werd het construct "proactiviteit" aangemerkt als een vaardigheid die het leren en de ontwikkeling van studenten tijdens klinisch onderwijs bevordert. Daarom onderzochten we: 1) in hoeverre klinische studenten bij de overgang naar een nieuw coschap proactief gedrag vertonen; en 2) de factoren die een rol spelen en het verband tussen proactief zijn en het zich sociaal geïntegreerd voelen in een nieuw coschap. Hoewel deze studie bedoeld 
was om RQ1 hierboven te beantwoorden, werden er ook antwoorden op RQ2 gegeven. Dit multimethodisch onderzoek omvatte data van 200 participanten en 18 individuele interviews van klinische studenten uit het $3^{e}, 4^{e}$ en $5^{e}$ jaar. Met behulp van vragenlijsten werden vijf vormen van socialisatiegedrag onderzocht, te weten: vragen om feedback, op zoek gaan naar informatie, onderhandelen over taken en rollen, het geven van een positieve invulling aan nieuwe ervaringen en relaties opbouwen met anderen. Hoewel studenten over het algemeen positief waren tijdens de start van een nieuw coschap, vonden ze het lastig om te onderhandelen over taken. De meer ervaren klinische studenten (vierde- en vijfdejaars) waren minder proactief dan junior (derdejaars) studenten. We constateerden dat proactief gedrag door klinische studenten tijdens een nieuw coschap voorafgegaan werd door: de intentie om proactief te zijn, het gevoel proactief te kúnnen zijn en het zich in een omgeving bevinden waarin proactiviteit wordt gestimuleerd. Persoonsgebonden factoren beïnvloedden de intentie om proactief te zijn; sociale factoren maakten dat de omgeving proactiviteit stimuleerde; en een combinatie van persoonsgebonden en sociale factoren beïnvloedde het vermogen van studenten om proactief te zijn. Ten slotte werd het geven van een positieve invulling aan nieuwe ervaringen bij het starten van een nieuw coschap in verband gebracht met sociale integratie. Deze bevindingen maken aannemelijk dat het ondersteunen en stimuleren van proactief socialisatiegedrag, met name bij klinische studenten uit latere jaren, de sociale integratie in de klinische omgeving kan bevorderen. Als antwoord op onze overkoepelende onderzoeksvragen gaf dit hoofdstuk aan dat proactief gedrag een ontwikkelingsvaardigheid is die bijdraagt aan zowel de persoonlijke als de professionele ontwikkeling. Verder is proactief gedrag een sociaal construct dat sterk beïnvloed wordt door teamleden, het zorgstelsel en het onderwijssysteem.

\section{Hoofdstuk Zes}

In Hoofdstuk 6 delen wij een empirisch onderbouwde reflectie op het gebruik van smartphones voor het verzamelen van kwalitatieve data in het medisch onderwijs. Dit hoofdstuk kwam voort uit ons besef dat het overgrote deel van de literatuur over transities tot nu toe gebruik heeft gemaakt van transversale onderzoeksopzetten. Bij deze onderzoeksbenaderingen bestond het risico op recall bias (vertekening van het geheugen), aangezien de data verzameld werden voor of nadat de studenten naar een nieuwe omgeving waren "overgegaan". Het gebruik van smartphones is tegenwoordig niet meer weg te denken uit vele gezondheidsgerelateerde terreinen, zoals de behandeling van patiënten, het onderwijs en gezondheidswetenschappelijk onderzoek. Wij wilden handvatten aanreiken voor het ontwerpen van smartphonetoepassingen, het gebruik ervan en voor het reflecteren op het gebruik van smartphones in onderzoek van medisch onderwijs. Om de vooruitgang van onderzoekstrajecten wereldwijd te bevorderen, is het van cruciaal belang dat onderzoekers hun ervaringen delen in de wetenschappelijke literatuur. We constateerden dat smartphones het onderzoeksdoel 
kunnen verruimen en binnen de uitgangspunten van kwalitatief onderzoek van medisch onderwijs passen. Onderzoekers moeten er bij het gebruik van smartphones in onderzoek van medisch onderwijs echter rekening mee houden dat deze de onderzoeksdata kunnen beïnvloeden, de privacy in gevaar kunnen brengen en voor voortdurende afleiding kunnen zorgen. Onze conclusie is dat wanneer onderzoekers smartphones willen gebruiken in toekomstig onderzoek van medisch onderwijs, zij openlijk moeten communiceren met participanten, moeten reflecteren en ethische toetsingscommissies moeten wijzen op hun verantwoordelijkheid om op het gebruik van smartphones in onderzoek van medisch onderwijs toe te zien.

\section{Hoofdstuk Zeven}

In Hoofdstuk 7 vatten we onze bevindingen uit alle studies samen, bespraken we deze en gaven we al doende antwoord op onze onderzoeksvragen. Met dit uitvoerige werk hebben we middels sociaal-culturele invalshoeken getracht inzicht te bieden in hoe bachelorstudenten Geneeskunde bij de overgang van preklinisch naar klinisch onderwijs hun weg vinden. Specifiek met betrekking tot onze eerste onderzoeksvraag (Op welke wijze draagt de overgang van preklinisch naar klinisch onderwijs bij aan de ontwikkeling van een professionele en persoonlijke identiteit van Geneeskundestudenten?) hebben we de vorming van een studentidentiteit zichtbaar gemaakt en zijn we erachter gekomen dat deze tot stand komt doordat studenten proactief zijn, hun zelfbeeld vormen en een reismindset aannemen. Met betrekking tot onze tweede onderzoeksvraag (Welke rol spelen sociale relaties bij de overgang van preklinisch naar klinisch onderwijs door studenten?) was onze bevinding dat de overgang naar klinisch onderwijs studenten een kans biedt om een sociaal netwerk op te bouwen en te benutten door doelbewust een dynamisch netwerk bestaande uit een diverse groep mensen op te bouwen. Onze bevindingen maken aannemelijk dat als we studenten hun ervaringen laten doormaken door hun ruimte te bieden voor reflectie, hun ondersteuningsnetwerken zichtbaar maken en de klinische teamleden bewust maken van hun invloed, transities omgevormd kunnen worden tot een kans voor studenten om over de uitdagingen die verandering met zich meebrengt heen te stappen richting empowerment en ontplooiing terwijl zij verder gaan naar een andere fase in hun loopbaan. 



\section{Impact paragraph}


In this short chapter, we will highlight the concrete conclusions from this body of work. We also explore the relevance and impact on stakeholders and wider society relevant to this work. We then explore the potential for access to the knowledge we shared in this thesis.

\section{Research summary}

This dissertation aimed to enhance the understanding of students' navigating the transition from classroom-based training to learning from patients in the clinical setting. We used concepts from multiple theories that relate to how social contexts influence learning in some way. We conducted four empirical studies using scoping review methodology, qualitative and mixed-methods designs all involving undergraduate medical students. We offer the medical education community insight into the transition of one transition period, from pre-clinical to clinical training. We first found that most authors in medical education research use negative discourse when describing transition to clinical training. Additionally, researchers primarily approach this transition as a problem to be solved cognitively with knowledge and skill sessions to prepare students for their new roles. We found researchers were less likely to consider the social and developmental aspects inherent in students' navigating change to learning and working with patients. We then found evidence that the transition to clinical training is an emotional period with negative and positive emotions that contributes to students' identity formation, being proactive about their learning and development and creation of students' social support networks. Transition to clinical training was both a threat and an opportunity for learning and development of undergraduate medical students, and the social context significantly contributes to whether threat or opportunity is more prominent.

\section{Relevance}

Medical trainees will undergo many transitions throughout their career development. Transitions are inevitable. The medical hierarchy leads to many medical students seeing themselves 'below the rubbish bins' in the clinical environment; they feel they have little value. Feeling lesser likely contributes to the challenges inherent in entering a new environment, seeing patients for the first time regularly, and trying to integrate into an environment which often ignores them. Importantly, some research suggests that transition periods are the source of numerous medical errors and psychological distress. Thus, both patients and trainees can be affected, and this thesis is relevant for both the medical community and patients. We also highlight that both healthcare institutions and health professionals at the workplace have a role to play in being open to newcomers, offering support and guidance, teaching lifelong learning skills and providing an outlet for active reflection. 


\section{Stakeholders that can benefit from these findings}

The results in this thesis are relevant to multiple stakeholders, some more surprising than others. This thesis with the dynamic, honest experiences presented in Chapter Two and other quotes presents medical students with an insight into the benefits of active reflection during stressful experiences. Additionally, Peers influence how positive a medical student tends to be when entering a clerkship and likely do not recognise how much emotional support they provide to one another during a transition. Similarly, many transitioning students lean on near-peer students in other cohorts for support. If a near-peer is exceptional at providing emotional and academic support, that near-peer may become overburdened in helping others in the academic years below them. This awareness is essential for the near-peer, the transitioning student and the institution. Explicit consideration of the 'who' in medical students' social networks was illuminating and showed students in our sample on whom they could depend during difficult times. Our results may be relevant to the medical and non-medical staff in clinical settings. These persons are responsible for the climate of the learning environment and creating a space where students feel comfortable to speak up, negotiate their learning goals and ask questions. Additionally, many junior and senior doctors, and nurses were present on students'support networks. Awareness of the importance students place on doctors and nurses for support is necessary. These results have relevance for academic educators and administrative staff; they too were meaningful members of students' networks as they transitioned to clinical training. Specifically, it could benefit institutions to have medical students map their social networks to expose the critical persons that transitioning students go to for information and guidance. Highlighting these persons could alert institutions of the need to support these persons for their often-unintended role of helping students adapt to a new environment. Institutions could therefore facilitate social network mapping sessions allowing students to map their networks and reflect on their options for support during stressful times. Additionally, institutions could utilise technology like smartphones to facilitate students' reflections and portfolio contributions; the mere act of reflection through audio-diaries was powerful for students in our sample. The family and roommates of medical students also have an essential role to play. These were often stable relationships and family, and roommates, should remain available where possible to be an outlet for medical students to vent about stressful days and a place where students can gain advice from outside the medical field.

\section{Access to findings}

The target groups mentioned above can access three papers from this thesis that are available as published manuscripts (Chapters Two, Four and Six); all are open access. Chapters Three and Five are undergoing peer review. Between 2017 until the present, some of these target groups have already seen the content in this thesis at national 
and international conferences - the annual conference of the Association for Medical Education in Europe (AMEE), the Rogano Conference, the annual meeting of the Australian New Zealand Association of Health Professions Educators, online virtual sessions for the Association of scientific medical education (ASME) organisation and local departmental meetings in the Netherlands and Australia. As publications occurred, most members of this research team shared short conclusions on personal Twitter social media pages. Social media interactions were reminiscent of in-person coffee break/water-cooler talks. Further, we also shared our findings on formal online videoconferencing sessions with worldwide participation. Over the next one to two years, outputs from this thesis will continue. This thesis will be printed as a book and placed online in both The Netherlands and Australia. Some participants used their data transcripts and social network maps as part of their mandatory portfolio at their institution. 

Appendices 


\section{ABOUT ANIQUE}

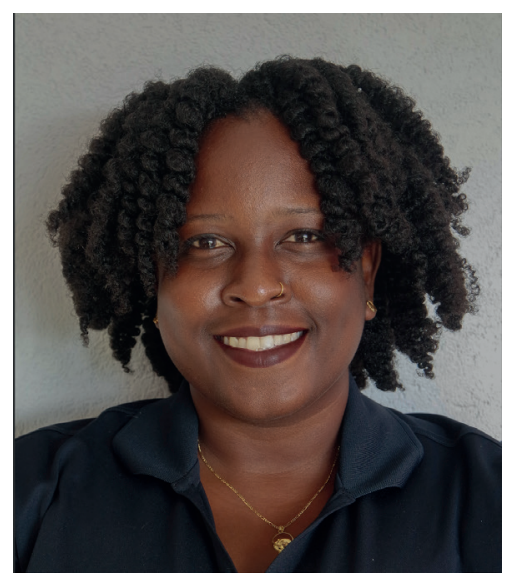

Dr. Anique Atherley is a black, female medical doctor from the south of the gem of the Caribbean Sea-Barbados. Anique completed medical training at the University of the West Indies (The UWI) and medical internship at the Queen Elizabeth Hospital in Barbados. During her internship, she met Dr. Charles G. Taylor Jr who opened her eyes to the field of medical education. She then went on to complete, with merit, a master's degree in public health (epidemiology) from the University of Liverpool in the United Kingdom. With Dr. Taylor's guidance, she took on a role as a Junior Research Fellow in Medical Education at The UWI where she led medical education research projects and contributed to teaching undergraduate medical students research methods and other public health concepts. Her love for education starting during medical school teaching her peers and preparing presentations; and blossomed when she had the teaching opportunities at The UWI. She also completed numerous online courses in health professions education and graduated in 2018 with a Postgraduate Diploma in University Teaching and Learning from The UWI, Cave Hill in Barbados. During her time at The UWI, she was the coordinator of the Medical Education Learning Community (MELC) and contributed to the creation of a career-advising symposium highly rated by medical students.

Then, Anique received the opportunity she had been searching for. After the passing of her beloved mentor DrTaylor, she knew she wanted to complete a doctorate in Medical Education and continue her academic journey as an early career medical educator. She was chosen as the inaugural recipient of a PhD scholarship for a dual doctoral degree in medical education from the School of Medicine at Western Sydney University and School of Health Professions Education (SHE) at Maastricht University. She began her PhD trajectory in September 2017 where she began the work seen in this thesis. Along this journey to becoming a medical education researcher, Anique received a Travel Grant from Medical Education' Association of Scientific Medical Education in 2019, she gained experience facilitating problem-based learning sessions at WSU, she wrote her first invited commentary in Medical Education (journal), co-organised national and international conferences (e.g., SHE academy) and even published an AMEE (Association of Medical Educators in Europe) Guide (No. 130). To this day, she has published over 15 peer-reviewed articles and has conducted workshops and made presentations in the Netherlands and Australia. As her stars align, Anique proudly is now at the end of her doctoral journey in medical education. 
Having completed her PhD, Anique keenly remains involved with SHE through contributing to the master's in health professions education programme (MHPE). Currently, she is an Assistant Professor in the Academy of Teaching and Learning at Ross University School of Medicine (RUSM) in Barbados. Here she has joint responsibility for student academic coaching and faculty development She is excited to contribute to this vibrant department at RUSM and hopes to bring educational research to the forefront and mentor faculty in providing evidence-based teaching. Lastly, she is also the managing director of a small research coaching company where she also helps postgraduates through their research process.

Personally, Anique also contributes to the community and she is the co-founder of 'Drops of Love' - an organisation that offers public education regarding blood donation to increase voluntary donations in Barbados. Additionally, during this trajectory, Anique co-founded a small company in Barbados that provides outdoor movie experiences at private events and became the adopted mom of two fur babies-Chai \& Spyce. Anique loves marine life and enjoys spending time with loved ones who roll their eyes when she 'gets all academic on them' but who always know how to make her laugh. 


\section{LIST OF PUBLICATIONS}

\section{Related to thesis content}

Atherley, A, Teunissen, PW, Hegazi, I, Hu, Wendy ,Dolmans, D.. (2020), 'Exploring the lived reality of transitioning from pre-clinical to clinical training' (research paper) [Under Review] [Thesis paper]

Atherley, A, Teunissen, PW, Dolmans, D., Hu, Wendy, Hegazi, I. (2020), 'Medical students' socialization tactics when entering a new clinical clerkship: a mixed methods study of proactivity' (research paper) [Under Review] [Thesis paper]

Atherley, A, Nimmon, L., Teunissen, PW, Dolmans, D., Hegazi, I, Hu, Wendy. (2020), 'Students' social networks are diverse, dynamic and deliberate when transitioning to clinical training' Medical Education Early Online View [Thesis paper]

Atherley, A, Hu, W, Teunissen, PW, Hegazi, I, Dolmans, D, (In Press) 'Appraising the use of smart phones and apps when conducting qualitative medical education research AMEE Guide, Medical Teacher [Thesis paper]

Atherley, A, Dolmans, D, Hu, W, Hegazi, I, Alexander, S, Teunissen, P. W. (2019), 'Beyond the struggles: a scoping review on the transition to undergraduate clinical training' Early view, Medical Education [Thesis paper]

Atherley, A, and Taylor Jr., C (2017) "Student perceptions of clerkship handbooks." The clinical teacher 14.4: 242-246. [Related to thesis]

Atherley, AE, Hambleton, I, George, C, Unwin,N, Lashley, PM \& Taylor Jr., CG (2016) 'Exploring the transition of undergraduate medical students into a clinical clerkship using organizational socialization theory' Perspectives on Medical Education; 5(2), 78-87 [Related to thesis]

\section{Medical Education papers not related to thesis}

Atherley, A, Meeuwissen, SNE (2020) Time for change: Overcoming perpetual feelings of inadequacy and silenced struggles in medicine Medical Education 54 (2), 92-94

Foo JS, Atherley, A, Ash J, Hu W (2020) Discussion Paper: The Canberra Meeting: An initiative for building research capacity in health professions education. Focus on Health Professional Education: A multi-professional Journal 21 (2), 48-54 
Taylor, C, Atherley, A, Murphy, M (2016) 'Towards an inpatient diabetes curriculum: medical student generated aims, objectives and methods for ward-based learning of non-critical, non-perioperative inpatient diabetes care, Diabetic Medicine 33(6), 827-834

Atherley, A \& Taylor, C (2015) 'This thing called life' Perspectives on Medical Education 4(4), 200-202

Taylor Jr., CG, Atherley, A, George, C, Morris C (2014) 'How we implemented a classroombased educational intervention for ward-based diabetes care' Medical Teacher 37 (8), 718-722

\section{Public Health Papers}

Pijls, B.G., Jolani, S., Atherley, A., Derckx, R.T., Dijkstra, J.I., Franssen, G.H., Hendriks, S., Richters, A., Venemans-Jellema, A., Zalpuri, S. and Zeegers, M.P., 2021. Demographic risk factors for COVID-19 infection, severity, ICU admission and death: a meta-analysis of 59 studies. BMJ open, 11(1), p.e044640.

Taylor CG, Taylor G, Atherley A, Hambleton I, Unwin N, Adams OP. (2017) The Barbados Insulin Matters (BIM) study: Barriers to insulin therapy among a population-based sample of people with type 2 diabetes in the Caribbean island of Barbados. Journal of Clinical \& Translational Endocrinology; 8, 49-53

Taylor CG, Taylor G, Atherley A, Hambleton I, Unwin N, Adams OP. (2017) Barbados Insulin Matters (BIM) study: Perceptions on insulin initiation by primary care doctors in the Caribbean island of Barbados. Primary care diabetes; 11(2):140-7.

Atherley, A, Whittington, A, Taylor, C, Jonker, C (2016) 'Knowledge, attitudes and practices towards blood donation in Barbados' Transfusion Medicine; 26(6), 415-421

Taylor, C, Bynoe, K, Worme, A, Atherley, A, Hambleton,I, Husbands, A., Unwin, N. (2015) 'A checklist that enhances the transmission of education to patients during insulin initiation: a randomized controlled trial' Diabetic Medicine 33(9), 1204-1210 


\section{ACKNOWLEDGEMENTS}

Maw, Paw, I literally could not have even thought about pursuing this without you! Thank you for being a consistent source of psychological, spiritual + financial support. Thank you for showing me the value of maintaining family ties, to give of my best, to be compassionate to myself and others + above all to have a grateful heart. Love you both!

Kéo, Shonelle, I am thankful you are alive to witness this moment with me. I cannot imagine my life without you. Thank you for all your support on my journey even amidst your own trying times. Your strength inspires me.

Iman, thank you for being so gentle and caring. I admire your nurturing leadership style and I hope someday I can emulate that as I gain more leadership responsibility in my career. Thank you for your guidance over these past years. I hope we can work together in the future again. I can't wait for you to visit me in Barbados!

Wendy, thank you for being half of the team that even picked me! I feel so honoured to be your inaugural joint PhD scholarship candidate. Thanks for following me down rabbit holes and pulling me out when necessary. Thank you for being open to crazy meeting times and providing so much guidance along my journey. I look forward to working with you in the future! I can't wait for you to visit me in Barbados!

Pim, your visit to Sydney felt like it was as much for me as it was for you. Thank you for sharing your family with me along with your critical mind and being supportive of where I wanted to take my research process. Thank you for asking about my desires and dreams and placing that at the forefront of every discussion we have ever had. You remain an inspiration to me and truthfully remind me a lot of my mentor Dr. Charles Taylor who is no longer here. In that way, I believe it was serendipity (and Diana) that brought you to my research team and I remain forever grateful. I look forward to working with you in the future! I can't wait for you to visit me in Barbados!

Diana, words cannot express how lucky I feel to be one of your PhD candidates. Your persistence in making sure I was always okay psychologically and academically was refreshing. You challenged me like none other but in a way that always made me and my work better. I don't know how you did it! Your visit to Sydney was a needed breath of fresh air for me. I look forward to continuing working together as I create my space in the health professions education field. I can't wait for you to visit me in Barbados!

Laura, thanks for coming on board! Your intellect is intimidating yet nurturing and I'm honoured to have met and learn from you! I can't wait for you to visit me in Barbados! 
Renee, your visit to Sydney was so lovely. I always tell myself I remember when you were but a name in many articles I read before my PhD journey. Meeting and getting to know a bit of you and your story have been a highlight of my life that I won't forget. Keep doing you and I truly hope we can work on something together soon! I can't wait for you to visit me in Barbados!

All SHE and WSU PhDs and staff, thank you for coffee breaks + sharing your perspectives.

To my colleagues at The UWI, Prof. Branday and Drs Lashley, George, Adams, and the Public Health Group, thank you for supporting my career to this day.

To my new department at RUSM, I look forward to our academic adventures to come.

Rhe, Khal, Dom, Jaye (+ my boys), Les, know that your support does not go unnoticed.

Uncle James, Aunt Steph, Lisa, Michael, Kyrk, Davron, + my entire family who kept checking up on + praying for me, I love you! S.I.P. Grange $\bullet$

My research coaching clients in the Caribbean, thank you for the symbiotic relationship that allowed me to coach you through your own research while you allowed me a space to nurture my skills while you helped me financially.

Juliët, while I was in Maastricht you never stopped making me feel loved and supported. Your kindness and thoughtfulness are humbling, and I can only hope I make you feel half as supported and you ensure you do for me. It's been a pleasure and I look forward to supporting you as you complete your PhD! I can't wait for you to visit me in Barbados!

Steph, you are one of the most selfless individuals I have ever met, thanks to you + Mark for a place to lay my head without restriction! Thanks for taking the time to read my gibberish weekly + making it better. Thank you for making me feel loved when I was living in Maastricht and giving me insight into your journey. I hope I have left as much as an impression on you as you have on me. I can't wait for you to visit me in Barbados!

To my seesteers! I strive to set a great example for you, but you make me so proud! Thanks, Astrid for the best layovers and being my unofficial room-mate now in Barbados. Akili, thanks for making home, home. The past years I sometimes felt like a failure not having enough resources or time to truly be there for you both, but I hope I never cease to make you feel loved. In this next chapter I'll do better! 
Chaiץ, the most loyal, study buddy ever! You warm my heart and my feet every single day. You have changed me for the better, as I'm now responsible for a living thing outside of myself; and yet, you take care of me. I hope to always make your tail wag until we part. Spyce, Marley thanks for sharing your wet noses and curiosity with me!

Greg, Rashida. I could not complete this section without an intentional huge, thank you to you for your support and relentless kindness over these past 3.5 years. I hope to reciprocate this soon!

Lynn, thanks for constantly motivating to be my best and most authentic self and for accepting me exactly as I am. I'm so lucky to be one of your chosen few in this thing we called life.

Kendi, Thanks for checking in all the time and visiting me on the other side of the pond! I love you and truly am grateful for your kindness in helping me when I needed it. I'll never forget all you've done for me and I look forward to doing the same for you now! Love you.

Sonita. Your financial kindness over the past 3.5 years allowed me not to worry + eased me financially when I needed it most. You are irreplaceable. Thanks for talking off my ear when I was commuting and scolding me when I went AWOL. I love you and look forward to doing half as much in the next chapter of my life as you have done for me in this current one.

Ty, you hardly missed an airport goodbye or a welcome home, you are a constant in my life. Thank you for daily check-ins, asking about the new people in my life as I visited other countries, encouraging me to go socialise even though I sometimes didn't listen and incessantly making sure I wasn't lonely. Love and miss you.

Last, but in no way least, Nikki...btw, here is proof that even before your final examinations, I knew that l'd defend this thesis with you as Dr. Nicole M.E. Branch MBBS DM (Obstetrics and Gynaecology)! Congrats again, but also thanks for being my sestra + personal cheerleader, this $\mathrm{PhD}$ would literally not have been possible without you. Thanks for showing up through it all, visiting me wherever I was + reminding me to take breaks. Love you 'til the wheels fall off + beyond. Words do me no favours here. Thank you. 


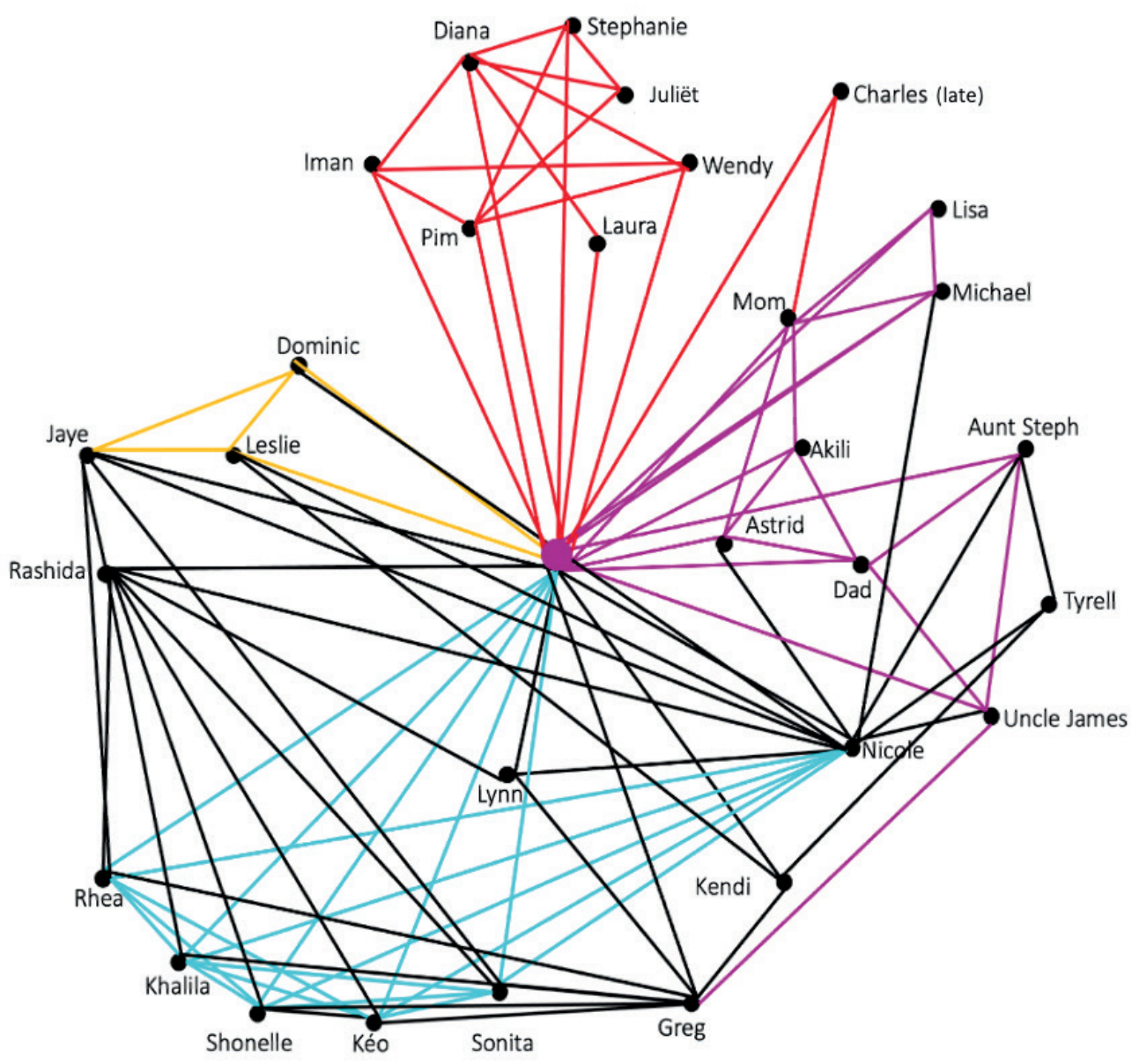

My social support network for this PhD Trajectory 


\section{SHE DISSERTATION SERIES}

The SHE Dissertation Series publishes dissertations of PhD candidates from the School of Health Professions Education (SHE) who defended their PhD theses at Maastricht University. The most recent ones are listed below. For more information go to: https://she.mumc.maastrichtuniversity.nl

Chim, H.Q. (30-03-2021) Physical Activity Behavior and Learning in Higher Education

Dominguez, L.C. (23-02-2021) Persistence in surgical training: The role of job crafting and leadership

Bindels, E. (22-02-2021) DOING WELL, GETTING BETTER; Facilitating physicians' reflection on their professional performance

Zafar Iqbal, M. (15-12-2020)_All stakeholders matter in faculty development: Designing entrustable professional activities for small group facilitation

Tran, QT. (09-12-2020).Nationwide implementation of medical skills training laboratories in a developing country: studies from Vietnam

Pacifico, J. (30-11-2020) Making the Implicit Explicit: Uncovering the Role of the Conceptions of Teaching and Learning and the Perceptions of the Learning Climate in Postgraduate Medical Training.

Nishigori, H._(17-11-2020)_Why do doctors work for patients? Medical Professionalism in the era of neoliberalism

Oudkerk Pool, A. (06-11-2020) Competency-based portfolio assessment - Unraveling stakeholder perspectives and assessment practices

Geel van, K. (05-11-2020)_Lifelong learning in radiology: all eyes on visual expertise

Stammen, L. (16-10-2020) Pursuing - High-Value, Cost-Conscious Care - The Role of Medical Education

Meulen van der, M. (15-10-2020) Assessment of physicians' professional performance using questionnaire-based tools

Matsuyama, Y. (05-10-2020) Contextual attributes fostering self-regulated learning in a teacher-centered culture: learner's professional identity formation is a trigger

Rovers, S. (16-09-2020)_Growing knowledge: Supporting students' self-regulation in problem-based learning 
Bougeois-Law, G. (03-09-2020) Conceptualizations of remediation for practicing physicians

Giuliani, M. (19-05-2020)_A Critical Review of Global Curriculum Development, Content and Implementation in Oncology

Schreurs, S. (20-03-2020)_Selection for medical school; the quest for validity

Schumacher, D. (19-03-2020)_Resident Sensitive Quality Measures: Defining the Future of Patient-Focused Assessment

Sehlbach, C. (21-02-2020)_To be continued...Supporting physicians' lifelong learning

Kikukawa, M. (17-12-2019)

The situated nature of validity: Exploring the cultural dependency of evaluating clinical teachers in Japan

Kelly, M. (10-12-2019) Body of knowledge: An interpretive inquiry into touch in medical education

Klein, D. (06-11-2019) The performance of medical record review as an instrument for measuring and improving patient safety

Bollen, J. (01-11-2019)_Organ donation after euthanasia: Medical, legal and ethical considerations

Wagner-Menghin, M. (25-09-2019) Self-regulated learning of history-taking: Looking for predictive cues

Wilby, K. (02-07-2019) When numbers become words: Assessors' processing of performance data within OSCEs

Szulewski, A. (20-06-2019) Through the eyes of the physician: Expertise development in resuscitation medicine

McGill, D. (29-05-2019) Supervisor competence as an assessor of medical trainees: Evaluating the validity and quality of supervisor assessments

Van Rossum, T. (28-02-2019) Walking the tightrope of training and clinical service: The implementation of time variable medical training 


\section{ICO DISSERTATION SERIES}

In the ICO Dissertation Series dissertations are published of graduate students from faculties and institutes on educational research within the ICO Partner Universities: Eindhoven University of Technology, Leiden University, Maastricht University, Open University of the Netherlands, University of Amsterdam, University of Twente, Utrecht University, VU University Amsterdam, and Wageningen University, and formerly University of Groningen (until 2006), Radboud University Nijmegen (until 2004), and Tilburg University (until 2002). The University of Groningen, University of Antwerp, University of Ghent, and the Erasmus University Rotterdam have been 'ICO 'Network partner' in 2010 and 2011. From 2012 onwards, these ICO Network partners are full ICO partners, and from that period their dissertations will be added to this dissertation series.

List update February 8, 2021 (the list will be updated every year in January)

403. Wijnen, M. (01-02-2019) Introduction of problem-based learning at the Erasmus School of Law: Influences on study processes and outcomes. Rotterdam: Erasmus University Rotterdam

404. Dobbelaer, M.J. (22-02-2019) The quality and qualities of classroom observation systems. Enschede: University of Twente

405. Van der Meulen, A.N. (28-02-2019) Social cognition of children and young adults in context. Amsterdam: Vrije Universiteit Amsterdam

406. Schep, M. (06-03-2019) Guidance for guiding. Professionalization of guides in museums of art and history. Amsterdam: University of Amsterdam

407. Jonker, H.M. (09-04-2019) Teachers' perceptions of the collaborative design and implementation of flexibility in a blended curriculum. Amsterdam: University of Amsterdam

408. Wanders, F. H. K. (03-05-2019). The contribution of schools to societal participation of young adults: The role of teachers, parents, and friends in stimulating societal interest and societal involvement during adolescence. Amsterdam: University of Amsterdam

409. Schrijvers, M.S.T. (03-05-2019) The story, the self, the other. Developing insight into human nature in the literature classroom. Amsterdam: University of Amsterdam

410. Degrande, T. (08-05-2019) To add or to multiply? An investigation of children's preference for additive or multiplicative relations. Leuven: KU Leuven.

411. Filius, R.M. (23-05-2019) Peer feedback to promote deep learning in online education. Unravelling the process. Utrecht: Utrecht University

412. Woldman, N. (24-05-2019) Competence development of temporary agency workers. Wageningen: Wageningen University 
413. Donszelman, S. (06-06-2019) Doeltaal-leertaal didactiek, professionalisering en leereffecten. Amsterdam: Vrije Universiteit Amsterdam

414. Van Oeveren, C.D.P. (12-06-2019) ITHAKA gaf je de reis. Amsterdam: Vrije Universiteit Amsterdam

415. Agricola, B.T. (21-06-2019) Who's in control? Finding balance in student-teacher interactions. Utrecht: Utrecht University

416. Cuyvers, K. (28-08-2019), Unravelling medical specialists self-regulated learning in the clinical environment. Antwerp: University of Antwerp

417. Vossen, T.E. (04-09-2019) Research and design in STEM education. Leiden: Leiden University

418. Van Kampen, E. (05-09-2019) What's CLIL about bilingual education? Leiden: Leiden University

419. Henderikx, M.A. (06-09-2019) Mind the Gap: Unravelling learner success and behaviour in Massive Open Online Courses. Heerlen: Open University of the Netherlands

420. Liu, M. (13-09-2019) Exploring culture-related values in Chinese student teachers' professional self-understanding and teaching experiences. Utrecht: Utrecht University

421. Sun, X. (13-09-2019) Teacher-student interpersonal relationships in Chinese secondary education classrooms. Utrecht: Utrecht University

422. Wu, Q. (02-10-2019) Making Construct-Irrelevant Variance Relevant: Modelling item position effects and response behaviors on multiple-choice tests. Leuven: KU Leuven

423. Jansen, R.S. (11-10-2019) Dealing with autonomy: Self-regulated learning in open online education. Utrecht: Utrecht University

424. Van Ginkel, S.O. (23-10-2019) Fostering oral presentation competence in higher education. Wageningen: Wageningen University

425. Van der Zanden, P. (05-11-2019) First-year student success at university: Domains, predictors, and preperation in secondary education. Nijmegen: Radboud University Nijmegen

426. De Bruijn, A.G.M. (14-11-2019) The brain in motion: Effects of different types of physical activity on primary school children's academic achievement and brain activation. Groningen: University of Groningen

427. Hopster-Den Otter, D. (28-11-2019) Formative assessment design: A balancing act. Enschede: University of Twente

428. Harmsen, R. (10-12-2019) Let's talk about stress. Beginning secondary school teachers' stress in the context of induction programmes. Groningen: University of Groningen

429. Post, T. (11-12-2019) Fostering inquiry-based pedagogy in primary school: a longitudinal study into the effects of a two-year school improvement project. Enschede: University of Twente 
430. Ackermans, K. (20-12-2019) Designing Video-Enhanced Rubrics to Master Complex Skills. Heerlen: Open University of the Netherlands

431. Li, N (08-01-2020) Analyzing online in-service teacher training courses in China. Eindhoven: Eindhoven University of Technology

432. Figueroa Esquivel, F. (13-02-2020) Early childhood multidimensional development. A rapid and non-linear roller coaster. Groningen: University of Groningen

433. De Leeuw, R.R. (27-02-2020) Through the eyes of the beholder. Unfolding social participation "from within' the classroom. Groningen: University of Groningen

434. Schreurs, S. (20-03-20) Selection for medical school. The quest for validity. Maastricht: Maastricht University

435. Nugteren, M.L. (12-06-2020) What do I know and where do I go? The effects of guidance on task selection. Utrecht: Utrecht University

436. Wijns, N. (01-07-2020) On the hunt for regularities: An investigation of children's early patterning competencies. Leuven: KU Leuven

437. Duijzer, A.C.G. (25-08-2020) Reasoning about graphs in primary mathematics education. Utrecht: Utrecht University

438. Dijkema, S. (25-08-2020) Ready for takeoff? The relation between the type of teacher training program and daily teaching practices of Dutch beginning primary school teachers. Groningen: University of Groningen

439. Slot, E.M. (11-09-2020) Characterizing adolescents' interest: understanding multiplicity and dynamics in persons, objects and contexts. Utrecht: Utrecht University

440. Ping, C. (24-09-2020) Understanding Teacher Educators' Professional Learning . Eindhoven: Eindhoven University of Technology

441. Van Rijswijk, M.M. (16-10-2020) Experiences of continuity and discontinuity in student teachers' development. Utrecht: Utrecht University

442. Rovers, S.F.E. (16-09-2020) Growing knowledge; Supporting students'self-regulation in problem-based learning Maastricht: Maastricht University

443. Langeloo, A. (17-09-2020) Multilingual and monolingual children in kindergarten classrooms: Exploring teacher-child interactions and engagement as learning opportunities. Groningen: University of Groningen

444. Sekeris, E. (06-10-2020) Unravelling computational estimation development in 5to 7-year-olds Leuven: KU Leuven

445. Ter Beek, M. (29-10-2020) Supporting reading comprehension in history education: The use and usefulness of a digital learning environment Groningen: University of Groningen

446. Peppen, L.M. (25-09-2020) Fostering Critical Thinking. Generative processing strategies to learn to avoid bias in reasoning Rotterdam: Erasmus University Rotterdam 
447. Van Geel, K., (05-11-2020) Lifelong learning in radiology: All eyes on visual expertise Maastricht: Maastricht University

448. Donker, M.H. (20-11-2020) In DEPTh: Dynamics of Emotional Processes in Teachers - An exploration of teachers' interpersonal behavior and physiological responses Utrecht: Utrecht University

449. Janssen, E.M. (13-11-2020) Teaching Critical Thinking in Higher Education: Avoiding, Detecting, and Explaining Bias in Reasoning Utrecht: Utrecht University

450. Van den Broek, E.W.R. (09-10-2020) Language awareness in foreign language education. Exploring teachers' beliefs, practices and change processes Nijmegen: Radboud University Nijmegen

451. Kasch, J.A. (09-10-2020) Scaling the unscalable? Interaction and support in open online education Heerlen: Open University of the Netherlands

452. Otten, M. (30-10-2020) Algebraic reasoning in primary school: A balancing act Utrecht: Utrecht University

453. De Vrind, E. (25-11-2020) The SpeakTeach method, Towards self-regulated learning of speaking skills in foreign languages in secondary schools: an adaptive and practical approach Leiden: Leiden University

454. Tacoma, S.G. (15-11-2020) Automated intelligent feedback in university statistics education Utrecht: Utrecht University

455. Boonk, L.M. (04-12-20202) Exploring, measuring, and evaluating parental involvement in vocational education and training Heerlen: Open University of the Netherlands

456. Kickert, R. (04-12-2020) Raising the bar: Higher education students' sensitivity to the assessment policy Rotterdam: Erasmus University Rotterdam

457. Van der Wal, N.J. (09-12-2020) Developing Techno-mathematical Literacies in higher technical professional education Utrecht: Utrecht University 


\title{
Beyond the struggles
}

by Anique Atherley

\author{
Change, Fear \\ Inevitable, Problematic \\ Transitions; \\ An opportunity or a threat? \\ Through review, \\ Through reflection \\ Through rhyme, \\ Through relations \\ Through rationales and theory \\ We find \\ Emotions \\ Nervous, excited \\ Seeing patients for the first \\ They exclaimed \\ Being proactive \\ Finding role models \\ Changing mindsets \\ They develop \\ Building relationships. Deliberate, \\ Diverse \\ Dynamic \\ They feel supported \\ Transitions \\ A threat; if unsupported \\ An opportunity; with support and mindsets \\ Developing \\ Networking \\ An Asset \\ They grow \\ I grow \\ Toward the growth \\ and \\ Beyond the struggles \\ We both become something more
}

